\title{
INFLUÊNCIA DA OVARIECTOMIA NA MOVIMENTAÇÃO DENTÁRIA INDUZIDA: AVALIAÇÃO MICROSCÓPICA
}

\section{ALESSANDRO ANTONIO COSTA PEREIRA}

Tese apresentada à Faculdade de Odontologia de Bauru, Universidade de São Paulo, como parte dos requisitos para obtenção do Grau de Doutor em Odontologia

- Área de Patologia Bucal

\section{BAURU}

2000 


\section{INFLUÊNCIA DA OVARIECTOMIA NA MOVIMENTAÇÃO DENTÁRIA INDUZIDA: AVALIAÇÃO MICROSCÓPICA}

\section{ALESSANDRO ANTONIO COSTA PEREIRA}

Tese apresentada à Faculdade de Odontologia de Bauru, Universidade de São Paulo, como parte dos requisitos para obtenção do Grau de Doutor em Odontologia - Área de Patologia Bucal

$$
\text { (EDIÇÃO REVISTA) }
$$

Orientador: Prof. Dr. Luís Antônio de Assis Taveira

\section{BAURU}

2000 


\section{Pereira, Alessandro Antonio Costa}

P414i Influência da Ovariectomia na Movimentação Dentária Induzida: Avaliação Microscópica./ Alessandro Antonio Costa Pereira - Bauru, 2000 128p. :il.; $30 \mathrm{~cm}$

Tese (Doutorado) - Faculdade de Odontologia de Bauru. USP

Orientador: Prof. Dr. Luís Antônio de Assis Taveira 


\section{DADOS CURRICULARES}

\section{ALESSANDRO ANTONIO COSTA PEREIRA}

13 de junho de 1964

Lavras - MG

Filiação

$1984-1987$

1990

$1992-1995$

1990

1997

Associações
Data e local de nascimento

Paulo Costa Pereira

Iracema Carvalho Pereira

Curso de Graduação em Odontologia pela Universidade Vale do Rio Verde de Três Corações - UNINCOR

Especialização em Radiologia pela Universidade Vale do Rio Verde de Três Corações - UNINCOR

Curso de Pós-Graduação em Patologia Bucal, com Grau de Mestre, pela Faculdade de Odontologia de Bauru USP

Professor da disciplina de Patologia Bucal da Universidade Vale do Rio Verde de Três Corações - UNINCOR

Professor das Disciplinas de Patologia Geral e Bucal da Escola de Farmácia e Odontologia de Alfenas - EFOA

Sociedade Brasileira de Estomatologia Sociedade Mineira de Estomatologia Associação Brasileira de Odontologia 
A minha família pelo apoio e carinho e à Patrícia pelo amor e incentivo

Dedico esta conquista 
Ao Professor Doutor Luís Antônio de Assis Taveira

Orientador e especialmente um grande amigo, pelo conhecimento, atenção e paciência, atributos necessários à realização deste trabalho, meu agradecimento e minha admiração 


\section{Ao Prof. Alberto Consolaro}

Pelo incentivo permanente à busca de novos conhecimentos e pelos ensinamentos de Patologia que passam a nortear minha profissão

Ao Departamento de Patologia da Faculdade de Odontologia de Bauru, USP, aos seus professores: Denise Tostes Oliveira, Vanessa Soares Lara e Sérgio Augusto Catanzaro Guimarães

E seus funcionários: Sr. Valdir João Afonso, amigo especial, Juracy do Nascimento, Fátima Aparecida Silveira, Maria Cristina Carrara Felippe e Bernadete A Alves Camargo, pelo respeito, atenção e amizade

Á Biblioteca da Faculdade de Odontologia de Bauru, USP pela atenção e dedicação de seus funcionários

A todos os colegas de Pós- Graduação, em especial ao Denis, Ênio, Francisco, João Lilian, Margareth, Maria do Carmo, Nilce, Osmar, Renata, Simone, Washington meu carinho e gratidão pelos bons momentos

A todos meus sinceros agradecimentos 
Agradecimentos Institucionais:

À Reitoria da Universidade Vale do Rio Verde- UNINCOR, na pessoa de seu Reitor Prof. Dr. Adair Ribeiro, amigo e incentivador para a realização desta pós- graduação

A Direção da Faculdade de Odontologia de Bauru, USP, na pessoa de seu Diretor Prof. Dr. Aymar Pavarini

A Comissão de Pós Graduação da Faculdade de Odontologia de Bauru, na pessoa de seu Presidente Prof. Dr. Luiz Fernando Pegoraro

Ao $\mathrm{CNPq}$, pelo incentivo pecuniário 


\section{SUMÁRIO}

Resumo ix

1 - Introdução 2

2 - Revisão da Literatura 5

2.1 - Movimento Dentário Induzido 5

2.2 - Metabolismo Ósseo e Estrogênio 11

2.2 - Metabolismo Ósseo Alveolar e Estrogênio 18

3 - Proposição 23

4 - Material e Métodos 25

4.1 - Animais 25

4.2 - Grupos Experimentais 25

4.3 - Ovariectomia $\quad 27$

4.4 - Simulação de Ovariectomia $\quad 28$

4.5 - Instalação de Aparelhos para Movimentação Dentária 28

4.6 - Obtenção de Maxilas 29

4.7 - Análise Microscópica 30

5 - Resultados 36

6 - Discussão 107

$\begin{array}{ll}7 \text { - Conclusões } & 118\end{array}$

$\begin{array}{lr}\text { Referências Bibliográficas } & 120\end{array}$

$\begin{array}{ll}\text { Abstract } & 127\end{array}$ 
RESUMO 


\section{RESUMO}

A ovariectomia promove uma depleção na síntese de estrogênio, um hormônio com efeitos sobre o metabolismo ósseo. Com o presente trabalho propôs-se analisar os efeitos desta condição nos tecidos dentários e ósseos envolvidos na movimentação dentária induzida. Foram utilizadas ratas com e sem ovariectomia, que tiveram seus primeiros molares superiores movimentados durante 24 horas, três e cinco dias. A análise por microscopia óptica revelou a não interferência da depleção de estrogênio nos tecidos dentários duros, não sendo detectadas reabsorções dentárias. No tecido ósseo, constatou-se um significante aumento dos aspectos reabsortivos nos animais ovariectomizados em relação aos animais não ovariectomiz ados. O presente trabalho mostrou diferenças entre as áreas ósseas inter-radiculares e externas quanto à susceptibilidade à reabsorção durante a movimentação dentária, com as áreas interradiculares apresentando aspectos mais proeminentes de reabsorção óssea, independente da condição de ovariectomia. 
1 - INTRODUÇÃO 


\section{1 - INTRODUÇÃO}

A expansão e o maior acesso populacional ao tratamento ortodôntico, bem como a necessidade de correções ortodônticas em pacientes com modificações sistêmicas exigem novos conhecimentos acerca dos efeitos destas modificações nos tecidos dentário e ósseo envolvidos na movimentação dentária induzida.

Entre as alterações sistêmicas, têm-se as relacionadas ao estrogênio, hormônio ovariano que sabidamente interfere no metabolismo ósseo, caracteristicamente nos ossos longos ${ }^{1,9,11,12,16,38,40,43,52,53,65,66,67,68,69}$. Na literatura especializada, encontram-se poucos trabalhos relacionando 0 estrogênio ao osso alveolar e aos dentes, podendo citar PEREIRA ${ }^{39}$ e VASCONCELOS ${ }^{61}$ que analisaram a gravidez e o uso de anticoncepcional hormonal em animais submetidos à movimentação dentária induzida.

Outra modificação sistêmica relacionada ao estrogênio é a obtida com a ovariectomia ou com a falência dos ovários ${ }^{1,9,11,12,16,38,40,43,52,53,65,66,67,68,69}$, quando cessa a produção do estrogênio e iniciam-se os fenômenos característicos da menopausa ${ }^{11,17,25,43,59,63}$. Dentre estes fenômenos existem os relacionados ao metabolismo ósseo, observando-se uma taxa maior de reabsorção em relação à de formação óssea.

A relação da ovariectomia com a movimentação dentária induzi da não tem sido objeto de estudos, de acordo com a literatura consultada, encontrando-se apenas alguns trabalhos envolvendo ovariectomia, osso alveolar e dentes, mas sem a interferência do estresse mecânico $6,10,16,22,24,28,37,40$.

Devido à relação, isoladamente, tanto do estrogênio, quanto da movimentação dentária com o tecido ósseo, o presente estudo objetivou analisar se a ação concomitante da ovariectomia e do movimento dentário 
pode interferir com os aspectos biocelulares comuns à movimentação dentária induzida, permitindo uma maior compreensão dos mecanismos envolvidos na movimentação dentária e tornando-a mais segura. 


\section{2 - REVISÃO DE LITERATURA}




\section{2 - REVISÃO DA LITERATURA}

\section{1 - Movimento Dentário Induzido}

A primeira análise microscópica da movimentação dentária induzida foi realizada em 1904 e 1905 por Sandstedt, apud DAVIDOVITCH ${ }^{10}$, em incisivos e canino superiores de um cão, respectivamente, movimentados no sentido lingual e distal. Neste trabalho, utilizando forças leves, verificou-se nas áreas de pressão uma reabsorção óssea marginal e superfície radicular intacta. Com forças intensas notou-se na área de pressão perda de vitalidade do ligamento periodontal e reabsorção óssea nos espaços medulares, referida como reabsorção a distância. Nas áreas sob tensão, com forças leves e intensas, ocorreu neoformação óssea na parede alveolar com as espículas ósseas acompanhando o estiramento das fibras periodontais. Esta análise permitiu a formulação da hipótese de tensão e pressão, causando aposição e reabsorção ósseas, respectivamente.

SCHWARZ ${ }^{51}$, em 1961, pesquisou a movimentação dentária induzida em pré-molares de cães sob intensidades diferentes de forças e estabeleceu, após análise microscópica, os seguintes efeitos biológicos, nas áreas de pressão: 1 forças suaves e breves não causaram nenhuma alteração periodontal; 2 - forças suaves, em redor de 20 a 26 gramas por centímetro quadrado de superfície radicular promoveram reabsorção óssea contínua, sem reabsorção dentária e com restituição do ligamento periodontal e do osso após cessada a aplicação da força; 3 - forças intensas promoveram compressão dos capilares sangüíneos, isquemia e necrose, com comprometimento da superfície dentária; 4 - forças muito intensas causaram contato do dente ao osso, reabsorção óssea a distância e propensão à reabsorção dentária. Cessada a força havia a possibilidade de ocorrer reabsorção dentária contínua, necrose pulpar e anquilose alveolodentária.

WALDO; ROTHBLATT ${ }^{62}$, em 1954, utilizaram pela primeira vez ratos como modelos experimentais para a movimentação dentária induzida. Os autores analisaram microscopicamente as alterações teciduais após o movimento do 
primeiro e segundo molar superior provocado pela inserção de um elástico entre estes dentes. Em 24 horas de movimentação ocorreu, na área de pressão, estreitamento do ligamento periodontal e vasoconstrição, enquanto fenômenos opostos foram verificados nas áreas de tensão. Após 72 horas de movimentação, ocorreu intensificação dos fenômenos observados nas primeiras 24 horas, com reabsorção óssea e presença de clastos na área de pressão. Após cinco e sete dias de movimentação dentária notoutse também reabsorção radicular ocasional.

REITAN; RYGH ${ }^{42}$ estudaram as áreas livres de células, denominadas de áreas hialinas e os feixes de fibras colágenas do ligamento periodontal. As áreas hialinas ocorrem nas áreas de pressão devido ao estreitamento do ligamento periodontal e são dependentes da intensidade das forças aplicadas, sendo mais comuns com forças intensas e do tipo de movimento dentário, ocorrendo mais no movimento de inclinação. Os autores notaram que a reabsorção óssea a distância ocorre freqüentemente quando há formação de áreas hialinas. Com a retirada das forças, novas células e vasos sangüíneos restabelecem a normalidade do ligamento periodontal. Em relação às fibras colágenas, o estiramento e o deslocamento, no lado de tensão, causam resistência ao movimento, sendo necessária uma retenção do dente após a movimentação para acomodação das fibras e estabilização óssea.

$\mathrm{KVAM}^{23}$, em 1970, estudou as áreas hialinas após movimentação do primeiro molar superior de ratos, com forças entre 17 e 22 gramas. Os dentes foram movimentados lateralmente por períodos de dois a nove dias e a análise envolveu colorações de hematoxilina-eosina, van Gieson, Mallory, auto-radiografia e radiomicrografia. $O$ estreitamento do ligamento periodontal persistiu por dois dias após a remoção da força e comumente nas áreas de pressão ocorreu hialinização, acompanhada de reabsorções ósseas. Após removida a força, as áreas hialinas foram invadidas por células, indicando sua reparação. Na coloração por hematoxilina-eosina e em auto-radiografias as áreas hialinas mostraram-se delineadas, claras e homogêneas, circundadas por macrófagos na fase de 
reabsorção e invadidas por células na fase de reparação. Nas regiões apicais, houve maior incidência de áreas hialinas, que se mostraram mais irregulares.

Comparando a reação tecidual após movimentação dentária induzida em humanos, macacos, cães e ratos, REITAN; KVAM ${ }^{41}$, em 1971, observaram reações variadas e atribuíram-nas às diferenças de densidade óssea, número, distribuição e tamanho dos espaços medulares, das fibras colágenas e da celularidade do ligamento periodontal, entre os modelos experimentais. Especificamente em ratos, observaram poucos espaços medulares e tecido osteóide na superfície alveolar, podendo causar atraso na deposição óssea no lado de tensão. Os ossos de ratos mostraram muitas linhas de reversão e áreas regulares de reabsorção, compatíveis com uma intensa atividade remodeladora. Outra característica comum aos dentes de ratos com e sem movimentação dentária foi a reabsorção radicular cervical, explicada pela pequena quantidade de restos epiteliais odontogênicos no ligamento periodontal destes animais. O estudo destes autores demonstrou a relevância da densidade óssea nos experimentos com animais, mas ressaltaram que em experimentos de pequena duração há possibilidade de comparação aos experimentos realizados em humanos, que apresentam menor densidade óssea, espaços medulares amplos e numerosos.

STOREY ${ }^{55}$ relacionou, em 1973, a ocorrência de três fenômenos na movimentação dentária induzida: 1 - fenômeno bioelástico; 2 - adaptação bioplástica e 3 - deformação biorruptora dos tecidos. O ligamento periodontal e o tecido ósseo alveolar são deformados elasticamente por estresse mecânico, com alterações nas atividades celulares. Após alcançado o limite elástico ocorre uma deformação plástica, adaptadora e remodeladora no tecido conjuntivo e no sistema vascular. Isquemia, morte celular, inflamação e reparo representam a deformação biorruptora e ocorre com forças que excedem o limite bioplástico. Para conhecer os limites bioplásticos requer-se a medição das variáveis: tempo, espaço e tipos de forças aplicadas. 
$\mathrm{RYGH}^{45}$, em 1973, analisou o comportamento das fibras colágenas durante a movimentação dentária induzida em molares de ratos, em microscopia óptica e eletrônica. Após 6 e 12 horas as áreas do ligamento periodontal adjacentes ao tecido ósseo estavam hialinizadas, com aspecto homogêneo; após 2 e 3 dias, a hialinização era mais extensa e as fibras colágenas da área de pressão estavam orientadas paralelamente à superfície radicular. Após sete dias notou-se reparação caracterizada por proliferação celular e vascular; e aos 28 dias houve restabelecimento funcional das fibras colágenas com o ligamento periodontal recomposto da pressão, mostrando-se com aspecto semelhante ao das áreas não pressionadas. $O$ autor considera que $\mathrm{O}$ aspecto da área hialina deve-se à compressão das fibras colágenas e às modificações dos elementos circundantes, como a ruptura de membrana e os elementos vasculares fora dos vasos.

Estudos em microscopia óptica e eletrônica realizados por $\mathrm{RYGH}^{46}$, em 1974, objetivaram identificar as células envolvidas na reorganização das áreas hialinas, bem como se as características do tecido hialino influenciariam na diferenciação destas células. Promoveu-se a mesialização dos primeiros molares superiores de ratos com forças de 5, 10 e 25 gramas, por períodos de 30 minutos, 2, $6,24,48$ e 60 horas, 5, 714 e 28 dias. Ao final do experimento, o autor considerou que a substituição do tecido hialino é feita por diferentes tipos celulares do ligamento periodontal adjacentes à área hialina e com proliferação vascular. Os vasos sangüíneos foram removidos por enzimas leucocitárias seguindo sua fagocitose por macrófagos e fibroblastos. Células gigantes removeram a extensa massa amorfa e partículas maiores de células. $O$ autor não determinou, neste estudo, a origem das células fagocitárias envolvidas na remoção da área hialina.

Em 1986, RYGH ${ }^{47}$ et al. estudaram as alterações celulares e vasculares no ligamento periodontal, em primeiros molares de ratos Wistar movimentados com forças de 30 gramas. Observaram aumento do número de macrófagos adjacentes e distantes dos vasos sangüíneos, em reabsorções ósseas frontais e nas áreas de tensão, além de aumento na atividade vascular em áreas de 
pressão e tensão, e de destruição e reparação rápida de fibras colágenas. No osso alveolar, houve proliferação de vasos e células sangüíneas e perda da cortical óssea.

Em 1989, CADELL ${ }^{6}$ relatou reabsorções dentárias nos incisivos superiores de uma paciente com movimentação dentária induzida por elásticos verticais. A paciente nos últimos cinco meses de tratamento ortodôntico submeteuse a altas doses de progesterona. $\mathrm{O}$ autor associou um interação das reabsorções com a progesterona, justificando que altas doses deste hormônio diminuem o nível de cálcio.

HELLSING; HAMMARSTROM ${ }^{20}$, em 1991, pesquisaram a movimentação dentária induzida em ratas prenhes, não prenhes e não prenhes usando fluoreto de sódio. Ao exame microscópio foram observadas áreas hialinas e reabsorções radiculares e ósseas adjacentes a estas áreas. $\mathrm{Na}$ contagem de clastos não houve diferença significante entre as ratas prenhes e não prenhes, sendo menor no grupo de ratas não prenhes usando fluoreto. Os autores comentaram que a razão de maior expansão dos dentes nas ratas prenhes não é conhecida e sugeriram que o estrogênio causaria retenção de água no tecido conjuntivo, facilitando a compressão do ligamento periodontal e a movimentação dentária.

BRUDVIK; RYGH ${ }^{5}$, em 1993, utilizaram ratos para estudar a formação, o desenvolvimento e a reparação de áreas hialinas. Foram movimentados os molares superiores para mesial com força de 50 gramas e a avaliação foi feita em microscopia óptica com coloração por fosfatase ácida resistente ao ácido tartárico (TRAP) e em microscopia eletrônica. Os autores utilizaram períodos de 6 e 12 horas, 1, 2, 3, 4, 5, 7, 10, 14 e 21 dias. Os autores relataram uma associação entre reabsorção radicular e remoção da área hialina e propuseram a seguinte padronização: 1 - as células monucleadas fibroblastos-"like" TRAP negativas iniciaram a reabsorção radicular a partir da periferia da área necrosada; 2 posteriormente e abaixo da área hialina houve reabsorção radicular e na remoção 
da hialinização notaram-se células multinucleadas TRAP positivas; 3 - a remoção da força interrompeu a reabsorção radicular junto às áreas hialinas. Pode se concluir por uma relação entre a extensão das áreas hialinas nos dias 3 e 4 e a extensão da reabsorção radicular após 21 dias, mostrando que a raiz será completamente reabsorvida se houver uma força ativa e contínua ou se houver reativação da força durante as fases de reabsorção radicular, sendo necessário um intervalo sem forças ativas para ocorrer a reparação.

Em 1994, BRUDVIK; RYGH ${ }^{4}$ estudaram as células envolvidas na remoção do tecido hialinizado e na reabsorção radicular. Utilizaram molares de ratos movimentados mesialmente com força de 50 gramas e analisaram a região interradicular mesial da raiz distal em microscopia eletrônica. No grupo controle não foram encontradas células multinucleadas. No grupo experimental, aos sete dias, notaram células multinucleadas e algumas mononucleadas, lembrando clastos, mas sem borda em escova e zona clara. As células monucleadas estavam adjacentes à membrana citoplasmática das células multinucleadas. As fibras colágenas estavam desorganizadas e poucas inseriam-se no cemento. A raiz mostrava-se com superfície irregular, com macrófagos-"like" próximos ao cemento. Aos dez dias, no grupo experimental, notou-se angiogênese na parte central do ligamento periodontal e próximo à superfície radicular, além de um número maior de células multinucleadas e macrófagos -"like", e lacunas de reabsorção radicular, com células mono e multinucleadas, com e sem borda em escova.

PEREIRA ${ }^{39}$, em 1995, avaliou o comportamento dos tecidos envolvidos na movimentação dentária induzida em molares de ratas Winstar prenhes e usando anticoncepcionais. Os grupos foram divididos em controle sem movimentação dentária e sem prenhez ou anticoncepcional; grupo com movimentação dentária mas sem prenhez ou anticoncepcional, grupo com movimentação dentária e prenhez e grupo com movimentação dentária e uso de anticoncepcional. Após movimentação dentária induzida por sete dias, com força inicial de 60 gramas, foram analisadas as áreas de pressão representadas pela porção cervical da face 
mesial da raiz mesial e pela porção apical da raiz distal. As áreas de tensão foram representadas pela porção cervical da face distal da raiz distal e pela porção apical da raiz mesial. A análise em microscopia óptica dos fenômenos comumente envolvidos na movimentação dentária induzida não revelou diferenças significantes entre os grupos experimentais, concluindo-se assim, que não há interferência das alterações do estrogênio na movimentação dentária induzida no estado de prenhez e com o uso de anticoncepcionais.

VASCONCELOS ${ }^{61}$, em 1996, estudou morfologicamente o periodonto de sustentação submetido a forças excessivas, de 60 gramas, em ratas normais, em ratas na condição de prenhez e em ratas recebendo anticoncepcional, comparando a sensibilidade das faces externas do ligamento periodontal e das faces interradiculares septais. Os molares superiores foram movimentados por sete dias e a análise das áreas de pressão e tensão, em microscopia óptica, revelou que as alterações celulares e teciduais nas áreas inter-radiculares submetidas à pressão caracterizaram-se por exuberante reabsorção óssea a distância, reabsorção radicular, formação de extensas áreas hialinas com macrófagos associados; perda local de fibroblastos, cementoblastos e osteoblastos; presença de muitos clastos na superfície óssea e cementária e na periferia das áreas hialinas. Outra constatação do estudo indicou que as áreas inter-radiculares são mais sensíveis às forças, apresentando precocemente respostas celulares e teciduais, em comparação às áreas externas. Por fim, sugere que o estado de prenhez e do uso de anticoncepcional não interferem nas reações celulares e teciduais frente às forças mecânicas para movimentação dentária, tanto na área de pressão quanto na de tensão, no periodonto externo ou inter-radicular.

\section{2 - Metabolismo Ósseo e Estrogênio}

O tecido ósseo apresenta contínua remodelação com constantes processos de reabsorção e de neoformação ${ }^{8,27,30,32}$, sendo que a viabilidade óssea e 
a sua adaptação ao estresse é resultado da atividade de suas células, responsáveis por esta remodelação ${ }^{8,27,30}$.

A remodelação óssea ocorre em focos discretos, denominados de unidades de remodelagem óssea ou unidades de estrutura óssea, observados no osso cortical e trabecular, constituídas por osteoblastos, clastos e células progenitoras, formando em conjunto a unidade multicelular básica ${ }^{43,60}$. Os eventos da remodelação óssea nas unidades multicelulares básicas envolvem vários fatores, incluindo-se os hormônios que atuam diretamente ou não nas células e coordenam e regulam as suas atividades ${ }^{31,57}$.

Os osteoblastos contêm receptores para a maior parte dos agentes reabsortivos e respondem aos hormônios envolvidos na manutenção da homeostasia do cálcio bem como às citocinas produzidas localmente ${ }^{18,30}$.

Os clastos podem ser encontrados isolados ou em pequenos grupos, principalmente na interface dos tecidos moles e mineralizados, em uma área da matriz óssea mineralizada, dentro de lacunas de reabsorção denominadas de lacunas de Howship ${ }^{2,30,34}$. A ação destas células consiste na remoção de componentes orgânicos e inorgânicos da matriz extracelular do osso, podendo ser regulada por mediadores fisiológicos, patológicos e farmacológicos. Inicialmente há formação dos progenitores dos clastos nos tecidos hematopoéticos, seguindo-se a sua ativação na superfície óssea. Nesta fase participam os osteoblastos, que ao se retraírem expõem a superfície mineralizada e também secretam um fator ativador de clastos. Por fim, ocorre a reabsorção óssea pelos clastos ${ }^{30,44}$.

Há fatores sistêmicos e locais capazes de regular a remodelação óssea ${ }^{7,27,30,31,33,49}$. Entre os hormônios citam-se o paratôrmio ${ }^{30,31,64}$, a vitamina $\mathrm{D}^{31,49,64}$, a calcitonina ${ }^{13,59}$, o estrogênio ${ }^{13,30}$ e a progesterona ${ }^{13,30}$. Os mediadores locais mais importantes são as citocinas, tais como a interleucina 1, a interleucina 2 , a interleucina 6, o fator de necrose tumoral, o interferom gama $\mathrm{e}$ as prostaglandinas $^{10,27,31,33,49}$, que podem ser produzidas por células hematopoéticas, imunológicas, por osteoblastos e possivelmente por clastos. 
O estresse mecânico também exerce efeito sobre a remodelação óssea, principalmente no osso esponjoso, quando a imobilização aumenta a reabsorção e diminui a formação óssea ${ }^{30}$, por estimular a atividade celular ${ }^{10}$.

Os efeitos do estrogênio sobre o metabolismo ósseo têm sido pesquisados principalmente em ossos longos e abrange variada metodologia em relação à idade dos animais e aos períodos de ovariectomia ${ }^{12,58,65,66,67,68}$.

Os estrogênios e as progestinas são hormônios ovarianos esteróides derivados a partir do colesterol e sintetizados nos tecidos adrenal e gonodal ${ }^{52,64}$. Os estrogênios representam um conjunto de hormônios denominados de estradiol, estrona e estriol, com o estradiol ocorrendo em maior concentração plasmática e possuindo ação 12 vezes mais potente que a estrona e 80 vezes em relação ao estriol, considerado um metabólito periférico ${ }^{52,64}$.

Os hormônios esteróides atuam no ácido ribonucléico e na síntese protéica e interagem com as células principalmente pelo processo de difusão, ${ }^{9,64}$. No citoplasma das células existem receptores específicos aos quais o hormônio liga-se formando um complexo hormônio-receptor ativado e por ativação gênica é formado um RNA mensageiro que age nos ribossomos citoplasmáticos produzindo proteínas que alteram a função, o crescimento e a diferenciação celular ${ }^{9,52,64}$.

A ação dos hormônios esteróides depende de fatores tais como a sua presença na circulação sangüínea, principalmente na forma livre e à disponibilidade de receptores celulares ${ }^{9,52,64}$.

No início da puberdade, os estrogênios são secretados em grandes quantidades e promovem a proliferação celular, o crescimento dos órgãos sexuais femininos e o desenvolvimento dos aparelhos reprodutivos ${ }^{9,52,64}$. Além destes efeitos, os estrogênios aumentam a intensidade de crescimento dos ossos longos durante a puberdade e aceleram a união das epífises às hastes destes ossos ${ }^{3,9,52,64}$.

O mecanismo de ação dos estrogênios no tecido ósseo, apesar de não ser totalmente compreendido, pode ser por ação direta nos osteoblastos e por ação 
indireta, regulando outros hormônios que agem no metabolismo ósseo $9,14,35,36,59,60,63,69$.

Em torno de 45 anos de idade as mulheres sofrem interrupção natural da ovulação e inicia-se o processo denominado de menopausa. Entre as alterações orgânicas há uma redução e paralisação da produção de estrogênio. A falta de estrogênio pode levar a uma alteração óssea denominada de osteoporose caracterizada por uma diminuição da densidade óssea tornando os ossos suscetíveis a fraturas, estando representada por uma redução na quantidade dos minerais ósseos e da matriz óssea em um dado volume do tecido ósseo ${ }^{1,11,25,35,63}$.

A osteoporose corresponde a um desequilíbrio entre a formação e a reabsorção ósseas por modificação dos fatores reguladores da proliferação e diferenciação de clastos e osteoblastos e de suas células precursoras ${ }^{11,13}$. A ausência de estrogênio provavelmente torna os clastos hiperativos, com maior capacidade reabsortiva ${ }^{11}$. Além de um possível efeito direto, a deficiência de estrogênio parece causar excessiva produção de citocinas e de outros hormônios que acentuam o recrutamento de clastos e o aumento da perda óssea ${ }^{11,17,27,53,56,60}$.

A ovariectomia, definida como a remoção cirúrgica dos ovários, causa uma deficiência na produção de estrogênios e causa efeitos clínicos semelhantes aos da menopausa ${ }^{1}$.

Em 1985, WRONSKI et a ${ }^{66}$ analisaram as alterações ósseas em ratas ovariectomizadas. Utilizaram 18 ratas Sprague Dawley, com idade de 75 dias, com nove animais sofrendo ovariectomia bilateral e outros nove com simulação de ovariectomia, pela exteriorização dos ovários. Os animais foram sacrificados cinco semanas após a ovariectomia e nove e três dias antes do sacrifício os animais receberam tetraciclina como marcador ósseo. Analisaram-se histomorfometricamente as porções da região proximal das tíbias. Nos animais ovariectomizados ocorreu aumento tanto de clastos e quanto de blastos, com aumento da taxa de crescimento ósseo longitudinal e diminuição do volume ósseo trabecular, sendo este duas vezes maior nas ratas ovariectomizadas. Os resultados 
obtidos não permitiram uma explicação da alteração da massa óssea notada neste trabalho, sendo sugerido que o mecanismo patogênico envolve uma taxa maior de reabsorção em relação à de formação óssea, compatível com a patogenia da osteoporose. Para os autores uma taxa acelerada de reabsorção óssea por clastos individuais, bem como um aumento na população de clastos pode resultar em uma perda óssea maior na ovariectomia, mesmo com aumento do número de blastos e de sua atividade, ressaltando que o tempo de ovariectomia pode não ter sido suficiente para obter -se uma resposta esquelética à deficiência de estrogênios.

WRONSK ${ }^{65}$ em 1988 estudou em ratas ovariectomizadas os efeitos do tratamento de reposição hormonal com estrogênio no metabolismo do osso trabecular. Ratas Sprague Dawley com 95 dias de idade e pesando em torno de 260 gramas foram divididas em grupos experimentais e receberam injeções subcutâneas diariamente de $17 \beta$-estradiol em doses de $10 \mu \mathrm{g} / \mathrm{kg}, 25 \mu \mathrm{g} / \mathrm{kg}$, e $50 \mu \mathrm{g} / \mathrm{kg}$, consideradas, respectivamente, doses baixas, médias e altas. Os animais começaram a receber o estrogênio no dia seguinte à cirurgia de ovariectomia e foram sacrificados 35 dias após. Foram examinadas as metáfises proximais das tíbias em cortes longitudinais quanto à estrutura e remodelação ósseas. Os resultados permitiram ao autor constatar que $o$ tratamento com estrogênio protegeu os animais ovariectomizados da osteopenia, pela diminuição dos índices de remodelação óssea nestes animais, sugerindo-se que a reposição hormonal reestabelece o equilíbrio entre reabsorção e formação óssea, aumentado em relação ao primeiro na ovariectomia.

WRONSKI; CITRÓN; DANN ${ }^{67}$ pesquisaram, em 1988, as alterações ósseas sob ovariectomia bilateral por período variado de tempo, em 168 ratas Sprague Dawley, com idade de 90 dias e peso em torno de 240 gramas. Os animais foram divididos em grupos e sacrificados após $0,14,35,52,70,100125$ e 180 dias e a metáfise proximal das tíbias foram processadas para exame microscópico e quantificação histomorfométrica. Os resultados mostraram osteopenia e índices elevados de reabsorção e formação ósseas após 14 dias de ovariectomia. Aos 14 
dias, notou-se crescimento ósseo longitudinal significante nas ratas ovariectomizadas, mas pouco diferindo dos animais controle. A osteopenia tornouse progressivamente mais pronunciada até o $100^{\circ}$ dia de ovariectomia, após o qual mostrou-se estabilizada. A superfície de clastos e blastos mostrou um rápido aumento em ratas ovariectomizadas aos 14 dias, mantendo-se elevada até o $100^{\circ}$ dia. As ratas ovariectomizadas mostraram uma renovação óssea aumentada nos períodos iniciais, coincidindo-se com uma maior e rápida perda óssea, sugerindo-se uma associação temporal comum entre o desenvolvimento da osteopenia e a fase de maior renovação óssea, em animais ovariectomizados, que é consistente com observações relatadas sobre o comportamento esquelético em mulheres na menopausa.

DEVLIN; FERGUSON; CARTER ${ }^{12}$, em 1990, estudaram o metabolismo ósseo em ratas ovariectomizadas na idade adulta, com 11 meses de idade. Os animais foram sacrificados após $7,14,21,28,34,39,62,69,95,117,158,167$, 172, 175, 201 e 203 dias de ovariectomia e tiveram a região proximal do ilíaco analisada histomorfometricamente. Os autores notaram diminuição rápida do volume ósseo, com aumento da perda óssea trabecular e aumento na extensão da superfície osteóide, além de maior número de cavidades de reabsorção, utilizado para explicar as alterações ósseas. Devido à idade avançada dos animais, os autores consideram que as modificações ósseas ocorreram devido apenas às alterações hormonais.

Em 1990, SCHOT; SCHUURS ${ }^{50}$ estudaram a fisiopatologia da perda óssea em ratas ovariectomizadas e relataram que nas ratas normais a remodelação óssea caracteriza-se por um equilíbrio entre reabsorção e formação ósseas, e nas ratas ovariectomizadas há um desequilíbrio com o aumento da reabsorção óssea não sendo compensado pelo aumento da formação óssea. Os autores sugerem que após a deficiência de estrogênio os clastos formam lacunas de reabsorção profundas, e mesmo com a atividade blástica normal não há uma compensação quando da formação óssea. As investigações destes auto res permitiram-Ihes 
considerar que a perda óssea após ovariectomia não é mediada por mudanças nos níveis plasmáticos dos hormônios calcicotrópicos.

BAGH; MILLER, em 1994, compararam a ovariectomia e a imobilização óssea como causas de osteopenia trabecular. Utilizaram 42 ratas Sprague Dawley de 90 dias de idade, divididas em grupos ovariectomizados, imobilizados sem ovariectomia, imobilizados com ovariectomia e controle. O período experimental foi de 6 e de 12 semanas. Por meio de foto-absorção, microscopia eletrônica de varredura e histomorfometria, os autores analisaram a tíbia e o fêmur dos animais e concluíram que a imobilização causou uma perda óssea trabecular mais intensa, tornando-se maior quando em conjunto com a ovariectomia.

Em 1997, PENG et a ${ }^{38}$ pesquisaram em ratas ovariectomizadas a resistência óssea, utilizando 100 ratas Sprague-Dawley com 12 semanas de idade. Os animais foram divididos em grupos e sacrificados 0 , 2, 4, 8, 16, 28 e 40 semanas após a ovariectomia e a simulação de ovariectomia. Os fêmures dos animais foram cortados entre o terço médio e distal e as porções proximais foram usadas para medir a resistência mecânica, com uma carga de compressão constante, tendo a deformação óssea registrada. Os resultados apontaram que a carga máxima suportada ocorreu nas ratas com ovariectomia simulada, declinando nos períodos experimentais finais e se igualando à das ratas ovariectomizadas. Nas ratas ovariectomizadas, a carga máxima suportada permaneceu relativamente constante em todos os períodos experimentais, e significantemente menor que a observada nas ratas com ovariectomia simulada, exceto no último período experimental. Os autores também observaram que houve uma perda de osso trabecular maior nas ratas ovariectomizadas. Para os autores, a deficiência de estrogênio leva a uma significante e permanente perda de osso trabecular e que a resistência óssea à compressão foi diferente nos períodos experimentais iniciais e essa diferença desapareceu após longo período de ovariectomia, igualando-se à perda de resistência devido à idade, como observado nas ratas com ovariectomia simulada. 
Os autores ${ }^{38}$ salientam que há muitas semelhanças entre a perda óssea induzida por ovariectomia em ratas e em mulheres após a menopausa, incluindo um metabolismo ósseo aumentado, uma desigualdade entre a reabsorção e a formação ósseas, uma maior perda de osso trabecular em relação ao osso cortical, e uma fase inicial com rápida perda óssea, tornando-se lenta ao longo do tempo.

\section{1 - Metabolismo Ósseo Alveolar e Estrogênio}

$\mathrm{Na}$ revisão da literatura, pouco se encontra de material a respeito de aspectos morfológicos envolvendo os ossos alveolares e o estrogênio ${ }^{28,37}$.

Em 1954, STOREY ${ }^{44}$ analisou as alterações ósseas durante o ciclo reprodutivo normal e sob estresse mecânico representado pela movimentação dentária induzida do canino superior. Durante a primeira fase do ciclo menstrual notou uma diminuição da velocidade do movimento dentário; na segunda metade do ciclo menstrual notou um aumento da velocidade da movimentação dentária e pouco antes e durante a menstruação notou ausência de movimento dentário. $\mathrm{O}$ autor relata uma variação na movimentação dentária entre homens e mulheres, associando-a a mudanças fisiológicas e concluiu que na primeira metade do ciclo reprodutivo há uma dficuldade de movimentação dentária, quando os índices de estrogênios estão menores.

Em 1957, PIROSHAW; GLICKMAN ${ }^{40}$ estudaram os efeitos da ovariectomia no osso alveolar e na tíbia de camundongos jovens e velhos divididos em grupos com animais ovariectomizados, com simulação de ovariectomia e com animais não operados. Após 16 semanas do início do período experimental, os animais foram sacrificados e após análise microscópica os autores consideraram que houve alterações ósseas discretas nos animais ovariectomizados, sendo mais pronunciadas nos animais jovens. 
Em 1974, SALOMÃO; GRANDINI; OKAMOTO ${ }^{48}$ avaliaram a reparação alveolar após exodontias em ratas ovariectomizadas. Após 21 dias de ovariectomia, os autores extraíram os incisivos superiores e avaliaram o osso alveolar após 1, 4, 7, 10, 13, 16, 19 e 22 dias. Observaram nos animais ovariectomizados um atraso na reparação, com menor proliferação celular e formação de matriz extracelular, bem como na sua mineralização. Quanto à cortical e às trabéculas ósseas neoformadas, apresentaram reabsorção, sendo que alteração cortical foi comum a todos os grupos experimentais.

HIRAIDE $^{21}$, em 1986, estudou os efeitos do estrogênio no ligamento periodontal de ratos, após movimentação dentária pela inserção de elástico entre o primeiro e segundo molar, durante três dias. Um grupo de animais sofreu ovariectomia e recebeu injeção de estradiol-17- $\beta\left(E_{2}\right)$; outro grupo recebeu apenas as doses de estradiol, que foram iguais para todos os animais e variaram de 0,010,1 - 1 - 10 a 100 microgramas por 0,5 mililitro de solução salina diariamente. Como resultados notourse que a administração de estradiol-17- $\beta$ em machos e fêmeas inibiu o crescimento corporal; tanto nos machos quanto nas fêmeas, dos grupos tratados e com dentes movimentados, não ocorreram alterações morfológicas proeminentes no ligamento periodontal; nas ratas ovariectomizadas ocorreram alterações como aumento do número de clastos e reabsorção óssea avançada dependente da dose de estradiol-17- $\beta$; a presença de clastos mostroutse significantemente diferente entre machos controles e fêmeas ovariectomizadas e controles.

LI; NISHIMURA ${ }^{24}$, em 1994, avaliaram as cristas ósseas alveolares após exodontia de molares superiores em ratas ovariectomizadas, por meio de microscopia óptica e de varredura. Os animais com idade entre 40 e 42 dias sofreram as exodontias após dez dias da ovariectomia. Os ossos alveolares foram examinados após os períodos experimentais de 2, 4 e 8 semanas da exodontia. Os autores notaram nos animais-controle que as cristas ósseas apresentavam atividade de reabsorção indicada por grande número de lacunas de Howship em quatro 
semanas após a exodontia e em oito semanas notaram reabsorção em forma côncava lisa. Nos animais ovariectomizados, notaram menor atividade reabsortiva e formação de uma camada de tecido mineralizado separado do osso na crista residual destes animais. Para os autores este tecido mineralizado era compatível com osso condróide e pode ter sido formado por células osteogênicas com fenótipo condrogênico. Concluíram que a deficiência sistêmica de estrogênio pode alterar significativamente as características da crista óssea pós-exodontia.

HSIEH et al. $^{22}$, em 1995, analisaram os efeitos da ovariectomia na reparação óssea alveolar após exodontia de molares superiores de ratas com 35 dias de idade. A ovariectomia e a exodontia ocorreram no mesmo dia e os animais foram sacrificados após 5, 10 e 14 dias. A ovariectomia aumentou significantemente a reabsorção óssea vestibular e a formação óssea palatina; quanto à mi neralização, ela foi mais significante aos 14 dias após a ovariectomia e a taxa de aposição óssea foi maior após cinco dias da ovariectomia e da exodontia. Os autores ressaltam que a deficiência de estrogênio conseqüente à ovariectomia interfere com o metabolismo ósseo alveolar após exodontias.

Em uma estudo clínico envolvendo mulheres na menopausa e a densidade do osso alveolar, por meio de radiografias interproximais, PAYNE et $a^{37}$, em 1997, consideraram uma maior perda da densidade óssea em pacientes com deficiência de estrogênio.

GILLES et $\mathrm{al}^{16}$, em 1997, realizaram um trabalho para avaliar a perda óssea devida à osteoporose, que para os autores não é estudada em profundidade em relação aos ossos maxilares. Os autores quantificaram a perda óssea periapical na região de dentes molares de ratas ovariectomizadas e não ovariectomizadas, com 90 dias de idade e três semanas de ovariectomia. Foram administrados localmente a interleucina 1 e o Campylobacter rectus, um patógeno periodontal, no conduto radicular e feita avaliação radiográfica da evolução da perda óssea e o tamanho da lesão periapical. Os autores observaram que houve uma perda óssea maior entre as ratas ovariectomizadas em relação às não ovariectomizadas, tanto 
no grupo controle, como nos grupos que utilizaram interleucina e Campylobacter rectus para acelerar a perda óssea.

Em 1998, MARQUES ${ }^{28}$ realizou estudo dos efeitos da ovariectomia no osso maxilar de ratas com idade de 30,60, 90 e 120 dias e com períodos experimentais de 5, 10, 20, 30 e 40 dias após a ovariectomia. As áreas analisadas foram as cristas ósseas alveolares mesiais e distais e septo ósseo inter-radicular do primeiro molar superior. A análise em microscopia óptica e a medição computadorizada das linhas de reversão mostraram ausência de alterações significativas na orientação e morfologia das fibras colágenas; predomínio de fibroblastos fusiformes, arredondamento do ápice da crista óssea mesial, características morfológicas de reabsorção e formação ósseas, clastos distantes da superfície óssea ou em lacunas, formação de osteóide e espaços medulares aumentados e em maior número. Quanto às linhas de reversão, mostraram-se aumentadas nas ratas ovariectomizadas, principalmente nas idades de 60 e 120 dias e nos períodos experimentais maiores. A autora considera que o osso alveolar das ratas ovariectomizadas mostrou características de osteoporose, principalmente nos animais com idades de 60 e 90 dias, e com 40 dias de ovariectomia, e conclui que a osteoporose por ovariectomia interfere na morfolo gia óssea alveolar.

MAZZIEIRO $^{29}$, em 1998, analisou a influência dos bifosfanatos, considerados eficientes bloqueadores da reabsorção, na movimentação dentária induzida em ratos com 90 dias de idade e em tempos experimentais de 24 horas, 3 , $5,7,10$ e 21 dias. Após análise microscópica, o autor considerou que a administração de clodronato (bifosfanato) não interferiu nas condições experimentais durante o movimento dentário, apenas ressaltando uma presença mais intensa de infiltrado inflamatório mononuclear nos grupos experimentais com bifosfanatos. 
3 - PROPOSIÇÃO 


\section{3 - PROPOSIÇÃO}

De acordo com a revisão da literatura e de questionamentos dela oriundos, o presente trabalho propôs-se a avaliar por meio de microscopia óptica a influência do estrogênio nos tecidos dentário e ósseo envolvidos na movimentação dentária induzida em ratas e obedecendo os seguintes modelos experimentais:

1 - sem alteração hormonal

2- sob efeito de ovariectomia

3 - sob efeito de ovariectomia simulada

Far-se-á a análise comparativa entre os modelos experimentais das principais alterações microscópicas envolvidas na movimentação dentária induzida, como se segue:

1 - alterações celulares e teciduais do ligamento periodontal

2 - reabsorção e neoformação ósseas

3- reabsorção dentária 
4 - MATERIAL E MÉTODOS 


\section{4 - MATERIAL E MÉTODOS}

\section{1 - Animais}

Foram utilizadas 30 ratas da linhagem Wistar, Rattus norvegicus albinus provenientes do Biotério da Faculdade de Odontologia de Bauru, da Universidade de São Paulo. Os animais tinham 40 dias de idade e pesavam, em média, 125 gramas.

Durante o período experimental os animais permaneceram no Biotério da Disciplina de Patologia da Faculdade de Odontologia de Bauru, da Universidade de São Paulo, acondicionados em grupos de três animais em gaiolas de plástico, forradas com maravalha, com iluminação natural e temperatura ambiente e receberam alimentação sólida, na forma de ração* e água sem restrições.

\section{2 - Grupos Experimentais}

Grupo C - três animais sacrificados com 90 dias de idade e sem movimentação dentária induzida e ovariectomia.

Grupo MD 1 - três animais sacrificados com 91 dias de idade, com movimentação dentária induzida por 24 horas e sem ovariectomia.

Grupo MD 3 - três animais sacrificados com 93 dias de idade, com movimentação dentária induzida por três dias e sem ovariectomia. 
Grupo MD 5 - três animais sacrificados com 95 dias de idade, com movimentação dentária induzida por cinco dias e sem ovariectomia.

Grupo OV 1 - três animais sacrificados com 91 dias de idade, com movimentação dentária induzida por 24 horas e com 50 dias de ovariectomia.

Grupo OV 3 - três animais sacrificados com 93 dias de idade, com movimentação dentária induzida por três dias e com 50 dias de ovariectomia.

Grupo OV 5 - três animais sacrificados com 95 dias de idade, com movimentação dentária induzida por cinco dias e com 50 dias de ovariectomia.

Grupo OS 1 - três animais sacrificados com 91 dias de idade, com movimentação dentária induzida por 24 horas e com 50 dias de ovariectomia simulada.

Grupo OS 3 - três animais sacrificados com 93 dias de idade, com movimentação dentária induzida por três dias e com 50 dias de ovariectomia simulada.

Grupo OS 5 - três animais sacrificados com 95 dias de idade, com movimentação dentária induzida por cinco dias e com 50 dias de ovariectomia simulada. 


\begin{tabular}{|c|c|c|c|}
$\begin{array}{c}\text { Grupo } \\
\text { Experimental }\end{array}$ & $\begin{array}{c}\text { Idade dos } \\
\text { animais* }\end{array}$ & $\begin{array}{c}\text { Período de } \\
\text { MD }\end{array}$ & Período de OV ou OS \\
\hline C & 90 dias & sem MD & sem OV e OS \\
\hline MD 1 & 90 dias & 24 horas & sem OV e OS \\
\hline MD 3 & 90 dias & 3 dias & sem OV e OS \\
\hline MD 5 & 90 dias & 5 dias & sem OV e OS \\
\hline OV 1 & 90 dias & 24 horas & 50 dias de OV \\
\hline OV 3 & 90 dias & 3 dias & 50 dias de OV \\
\hline OV 5 & 90 dias & 5 dias & 50 dias de OV \\
\hline OS 1 & 90 dias & 24 horas & 50 dias de OS \\
\hline OS 3 & 90 dias & 3 dias & 50 dias de OS \\
\hline OS 5 & 90 dias & 5 dias & 50 dias de OS \\
\hline movimentaçáo dentária induzida; OV & ovariectomia; OS
\end{tabular}

MD - movimentação dentária induzida; OV - ovariectomia; OS ovariectomia simulada

* idade quando foi colocado o aparelho para MD, exceto Grupo C FIGURA 1 - Distribuição dos grupos experimentais

\section{3 - Ovariectomia}

A remoção dos ovários das ratas foi precedida pela sedação e anestesia com inalação monitorada de éter etílico ${ }^{15}$.

Após assepsia, realizou-se incisão bilateral, com lâmina de bisturi número 15, no abdômen, na região pré-pubiana, acessando-se e removendo 
os ovários de cada animal submetido a este procedimento, de acordo com FARRIS ${ }^{15}$. A região incisada recebeu sutura simples com fio de seda 4-0 e os animais foram novamente acondicionados em suas gaiolas.

O sucesso da ovariectomia foi constatado quando do sacrifício dos animais, pela ausência dos ovários e por intensa atrofia das trompas uterinas $^{28,66}$.

\section{4 - Simulação de ovariectomia}

Nas mesmas condições descritas para obtenção da ovariectomia, acessaram-se os ovários expondo-os, porém sem removê-los ${ }^{28}$.

\section{5 - Instalação de aparelhos para a movimentação dentária induzida}

Os animais foram anestesiados com pentobarbital sódico* diluído em água destilada e injetado via intraperitoneal, na dosagem de 30 miligramas por quilograma de peso corporal.

Após serem anestesiados, os animais foram posicionados em mesa operatória própria para este procedimento.

Os aparelhos ortodônticos foram confeccionados a partir de HELLER;NANDA ${ }^{19}$, constando de molas espiraladas e fechadas ${ }^{* *}$, de .006x.022 polegadas, com comprimento de seis milímetros.

As molas ortodônticas foram unidas ao primeiro molar superior direito e ao incisivo superior do mesmo lado, por meio de fio de amarrilho de 0,2 milímetros. O fio passava nos espaços interproximais dos dentes e teve seu posicionamento, nos dentes incisivos, reforçado por um sulco feito com 
broca troncocônica no terço gengival da coroa dentária, e pela colocação de resina composta***. (FIGURA 2)

Após a adaptação das molas, as mesmas foram estiradas para produzir uma força inicial de 50 gramas, aferida por um dinamômetro* $28-450 \mathrm{~g}$, número 006-013. O tamanho final de cada mola após estiradas foi medido por um compasso de pontas secas e calibrado, permitindo a padronização do estiramento. Não foram realizadas outras ativações de força durante o período experimental.

A movimentação dentária induzida pela mola ortodôntica ocorreu no molar, no sentido mesial e no incisivo, no sentido palatino, sendo apenas o primeiro movimento de interesse no presente trabalho. (FIGURA 2)

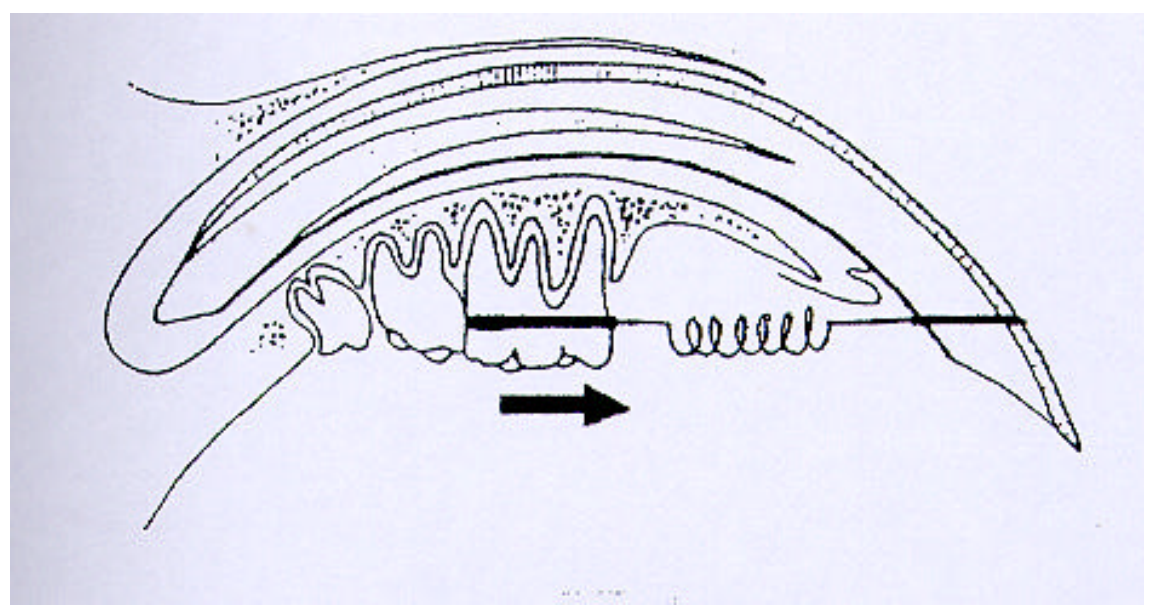

FIGURA 2 - Vista lateral da hemimaxila de rata com aparelho para movimentação dentária induzida posicionado no primeiro molar e no incisivo superiores

\section{6 - Obtenção das maxilas}

Os animais, ao término de cada período experimental, foram sacrificados pela inalação excessiva de éter etílico. Após decapitação suas cabeças foram dissecadas e os componentes epiteliais, fibrosos e musculares foram removidos, colocando-se as maxilas em formol a $10 \%$. 
As maxilas, após o período de fixação, foram desmineralizadas em solução de etilenodiaminotetracetatodissódico (EDTA) a 5\%, com pH 7,0, por 30 a 45 dias, sendo a solução trocada três vezes por semana e agitada diariamente.

As maxilas desmineralizadas foram analisadas macroscopicamente e seccionadas na região sagital do palato duro. As hemimaxilas foram preparadas para inclusão em parafina e coloração em hematoxilina-eosina de Harris e Lison, de acordo com os procedimentos histotécnicos adotados pela Disciplina de Patologia da Faculdade de Odontologia de Bauru, da Universidade de São Paulo.

Os cortes microscópicos foram realizados com espessura média de cinco micrometros no sentido mesiodistal paralelo ao longo eixo do primeiros molares.

\section{7 - Análise microscópica}

As lâminas obtidas no processamento histotécnico foram observadas em microscopia óptica, nas áreas correspondentes ao periodonto dos molares movimentados.

As raízes dentárias mesiovestibular e distovestibular foram separadas em porções mesial e distal e demarcadas por uma linha que as dividia na metade de seu comprimento longitudinal, com início junto à crista óssea alveolar e término junto ao forame apical, formando as regiões cervical e apical.

As áreas selecionadas para análise foram:

A - região cervical do lado mesial da raiz mesiovestibular, correspondente à área de pressão externa; 
B - região cervical do lado mesial da raiz distovestibular, correspondente à área de pressão inter-radicular;

C - região cervical do lado distal da raiz mesiovestibular, correspondente à área de tensão inter-radicular;

D - região cervical do lado distal da raiz distovestibular, correspondente à área de tensão externa.

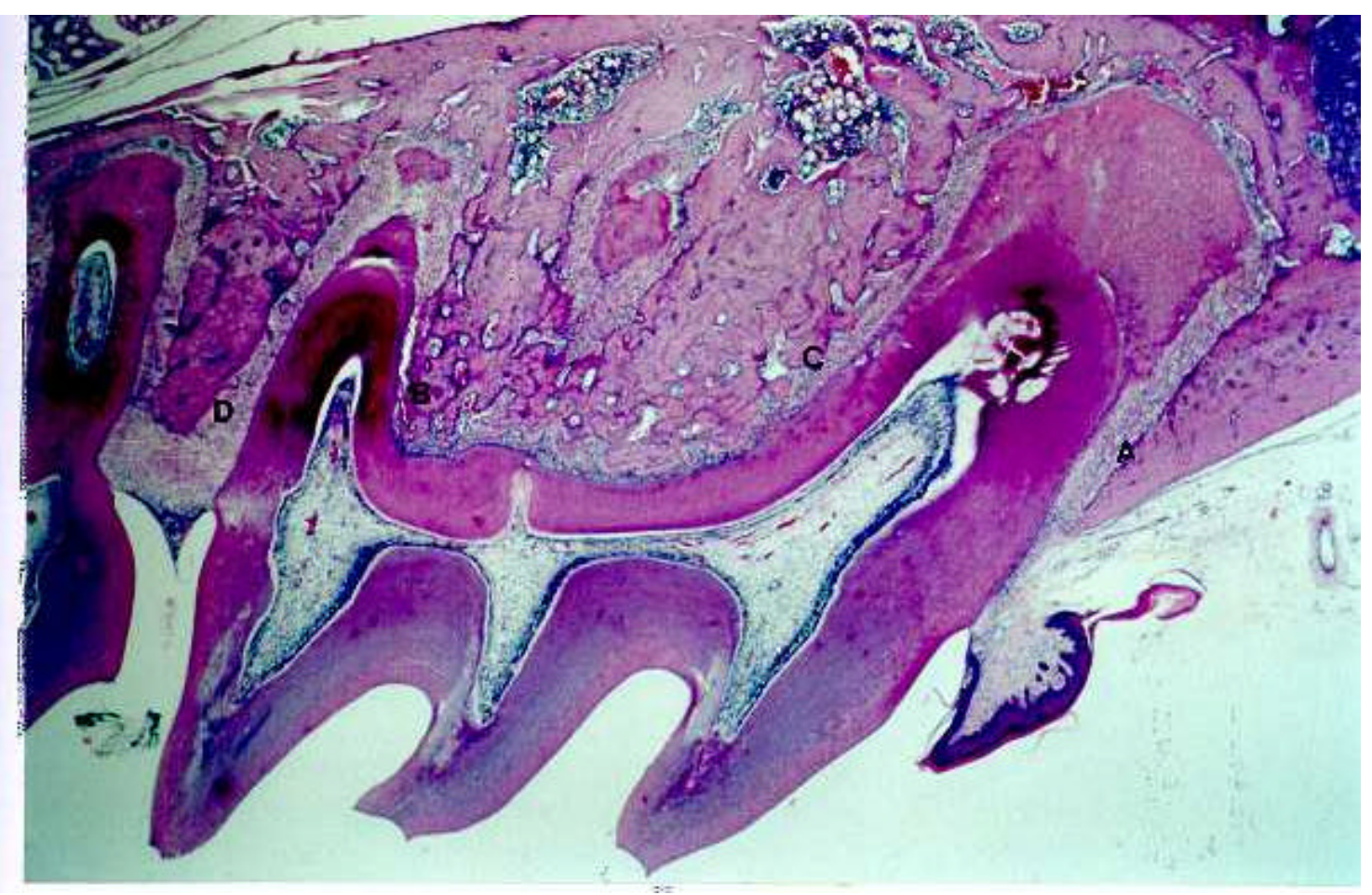

FIGURA 3 - llustração das áreas selecionadas para análise microscópica. $A=$ pressão externa; $B$ = pressão inter-radicular; $C=$ tensão interradicular e $\mathrm{D}=$ tensão externa. (Coloração $\mathrm{HE}$, objetiva 2,5x)

Os fenômenos biológicos comumente previstos na movimentação dentária induzida e observados nas áreas selecionadas para análise foram descritos subjetivamente, seguindo-se um roteiro para orientação e padronização, por meio de uma ficha confeccionada para esta finalidade.

Os principais fenômenos analisados foram: 
1 - reabsorções cementária e óssea, considerando as faces ósseas periodontal e endosteal e a crista óssea;

2 - neoformações e aposições cementária e óssea, considerando-se as faces ósseas periodontal e endosteal;

3 - regularidade e uniformidade das superfícies cementária e óssea, com presença ou não de tecido cementóide e osteóide, respectivamente;

4 - espessura e uniformidade do ligamento periodontal; presença e características de áreas hialinas; distribuição das fibras colágenas periodontais;

5 - vascularização sangüínea referente ao formato, calibre e número de vasos e às alterações circulatórias;

6 - infiltrado inflamatório, considerando-se tipo e localização;

7 - alterações envolvendo fibroblastos, osteoblastos, cementoblastos e clastos, referentes à morfologia, localização e distribuição. 
Registro dos achados microscópicos:

\begin{tabular}{|c|c|c|c|c|c|c|c|c|c|c|c|c|c|c|c|c|}
\hline & LOCALIZAÇA & & $\overline{A R E}$ & $\overline{E A D}$ & $\overline{E F}$ & $\overline{\mathrm{RE}}$ & ESS/ & $\overline{A O}$ & & & $\overline{A R E A}$ & $\overline{\mathrm{DE}}$ & $\overline{\mathrm{TE}}$ & $\sqrt{\mathrm{SS}}$ & $\overline{A O}$ & \\
\hline & & & Exte & rna & & & Inte & & & & Externa & & & $\operatorname{lnt}$ & & \\
\hline Fenômend & Esnécimes & 1 & 2 & 3 & & 1 & 2 & 3 & & 1 & 2 & 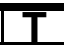 & 1 & 2 & 3 & \\
\hline Laraura & Aumentada & & & & & & & & & & & & & & & \\
\hline & Diminuída & & & & & & & & & & & & & & & \\
\hline Fibras & Ao acaso & & & & & & & & & & & & & & & \\
\hline colágena & Perpendicula & & & & & & & & & & & & & & & \\
\hline Areas & Pequenas & & & & & & & & & & & & & & & \\
\hline hialinas & Médias & & & & & & & & & & & & & & & \\
\hline & Grandes & & & & & & & & & & & & & & & \\
\hline Vasos & Dilatados & & & & & & & & & & & & & & & \\
\hline sangüíne & Colabados & & & & & & & & & & & & & & & \\
\hline & Hiperêmicos & & & & & & & & & & & & & & & \\
\hline Infiltrado & Neutrofílico & & & & & & & & & & & & & & & \\
\hline Inflamató & Mononuclea & & & & & & & & & & & & & & & \\
\hline & CGMIs & & & & & & & & & & & & & & & \\
\hline Restose & epiteliais de & & & & & & & & & & & & & & & \\
\hline & irreqular c/ & & & & & & & & & & & & & & & \\
\hline Face & irreqular s/ & & & & & & & & & & & & & & & \\
\hline periodont & linha de & & & & & & & & & & & & & & & \\
\hline & Osteóide & & & & & & & & & & & & & & & \\
\hline & Irreqular c/ & & & & & & & & & & & & & & & \\
\hline Face & Irregular s/ & & & & & & & & & & & & & & & \\
\hline endosteal & linha de & & & & & & & & & & & & & & & \\
\hline & Osteóide & & & & & & & & & & & & & & & \\
\hline Crista & Reqular & & & & & & & & & & & & & & & \\
\hline óssea & Irreqular & & & & & & & & & & & & & & & \\
\hline Superfície & Reqular & & & & & & & & & & & & & & & \\
\hline cementária & Irreqular c/ & & & & & & & & & & & & & & & \\
\hline & Cementóide & & & & & & & & & & & & & & & \\
\hline Reabsorcão & Dentinária & & & & & & & & & & & & & & & \\
\hline & Mitótico & & & & & & & & & & & & & & & \\
\hline Núcleo & Picnótico & & & & & & & & & & & & & & & \\
\hline & Cariorrexe & & & & & & & & & & & & & & & \\
\hline Quanto & Fasciculad & & & & & & & & & & & & & & & \\
\hline disposiç & Ao acaso & & & & & & & & & & & & & & & \\
\hline & Mitótico & & & & & & & & & & & & & & & \\
\hline Núcleo & Picnótico & & & & & & & & & & & & & & & \\
\hline & Cariorrexe & & & & & & & & & & & & & & & \\
\hline Quanto & Em & & & & & & & & & & & & & & & \\
\hline disposic & Ao acaso & & & & & & & & & & & & & & & \\
\hline Quanto & Justaposto & & & & & & & & & & & & & & & \\
\hline suberfíc & A distância & & & & & & & & & & & & & & & \\
\hline
\end{tabular}


continuação

\begin{tabular}{|c|c|c|c|c|c|c|c|c|c|c|c|c|c|c|c|c|}
\hline & & \begin{tabular}{l|}
1 \\
\end{tabular} & 2 & 3 & $\mathrm{~T}$ & 1 & 2 & 3 & $T$ & 1 & 23 & $T$ & & 2 & & $\mathrm{~T}$ \\
\hline \multirow{3}{*}{ Núcleo( } & Mitótico & & & & & & & & & & & & & & & \\
\hline & Picnótico & & & & & & & & & & & & & & & \\
\hline & Cariorrexe & & & & & & & & & & & & & & & \\
\hline \multirow{3}{*}{$\begin{array}{c}\text { Quanto } \\
\text { à } \\
\text { superfíc }\end{array}$} & A distância & & & & & & & & & . & & & & & & \\
\hline & Justaposto & & & & & & & & & & & & & & & \\
\hline & Em & & & & & & & & & & & & & & & \\
\hline \multirow{2}{*}{ Núcleo } & $\begin{array}{l}\text { Mitóticó } \\
\text { Picnótico }\end{array}$ & & & & & & & & & - & & & & & & -1 \\
\hline & Cariorrexe & & & & & & & & & & & & & & & \\
\hline \multirow{2}{*}{$\begin{array}{l}\text { Quanto } \\
\text { disposic }\end{array}$} & $\mathrm{Em}$ & & & & & & & & & & & & & & & 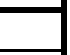 \\
\hline & Ao acaso & & & & & & & & & & & & & & & \\
\hline \multirow{2}{*}{$\begin{array}{l}\text { Quanto } \\
\text { superfíc }\end{array}$} & Justaposto & & & & & & & & & & & & & & & \\
\hline & A distância & & & & & & & & & & & & & & & \\
\hline \multirow[b]{2}{*}{ Núcleol } & $\begin{array}{l}\text { Mitótico } \\
\end{array}$ & & & & & & & & & & & & & & & \\
\hline & Picnótico & & & & & & 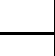 & & & 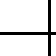 & & - & & & & - \\
\hline \multirow{3}{*}{$\begin{array}{c}\text { Quaanto } \\
\text { à } \\
\text { superfíc }\end{array}$} & \begin{tabular}{|l} 
Carıorrexe \\
A distância
\end{tabular} & & & & & & & & & & & & & & & \\
\hline & Justaposto & & & & & & & & & & & & & & & \\
\hline & & & & & & & & & & & & & & & & \\
\hline
\end{tabular}

CGMIs: células gigantes multinucleadas inflamatórias

FIGURA 3 - Modelo de ficha confeccionada para registro dos achados microscópios referentes aos fenômenos biológicos morfologicamente detectados na movimentação dentária induzida 
5 - RESULTADOS 


\section{5 - RESULTADOS}

\section{GRUPO C}

O grupo $\mathrm{C}$ corresponde aos animais com 90 dias de idade, sem movimentação dentária e sem ovariectomia.

1 - Área de pressão externa na raiz mesiovestibular na região cervical

No tecido ósseo nota-se crista alveolar levemente irregular e superfície periodontal pouco recortada e irregular. A superfície mostra-se revestida por osteoblastos justapostos e em paliçada, com linhas de reversão e sem lacunas de reabsorção. Na porção óssea endosteal há muitos osteócitos.

A superfície cementária está uniforme e revestida por cementoblastos justapostos e em paliçada, não sendo observadas lacunas de reabsorção.

O ligamento periodontal apresenta espessura uniforme e normal e bastante celularidade. Os fibroblastos encontram-se principalmente fusiformes, alguns ovalados e dispostos em fascículos. A alteração nuclear não é uma característica significante. As fibras colágenas dispõem-se paralelamente entre si e se inserem perpendicularmente nas superfícies óssea e cementária. Há vasos sangüíneos dilatados e discretamente hiperêmicos, não ocorrendo infiltrado inflamatório, nem restos de epitélio odontogênico. 
2 - Área de pressão inter-radicular na raiz distovestibular na região cervical

A superfície óssea periodontal mostra-se recortada e sem lacunas de reabsorção. Há linhas de reversão intensas e basófilas e revestimento parcial por osteoblastos justapostos em paliçada. $\mathrm{Na}$ face endosteal há poucos espaços medulares, geralmente amplos e ricamente irrigados.

A superfície cementária apresenta-se uniforme, regular e revestida por cementoblastos dispostos em paliçada, alguns ao acaso e não são observadas lacunas de reabsorção.

No ligamento periodontal, nota-se espessura regular, rica celularidade, com fibroblastos fusiformes, alguns ovalados e com núcleo picnótico, e distribuídos em fascículos e aleatoriamente. As fibras colágenas dispõem-se ao acaso e há discretas áreas hialinas. Ocorrem vasos sangüíneos pouco dilatados e colabados e alguns estão hiperêmicos. Não há infiltrado inflamatório.

3 - Área de tensão externa na raiz distovestibular na região cervical

A superfície óssea periodontal mostra-se levemente irregular e revestida parcialmente por osteoblastos justapostos, em paliçada e ao acaso, além de discretas linhas de reversão. Notam-se clastos dispostos a distância e não há lacunas de reabsorção. Na superfície endosteal são notados poucos espaços medulares e vários osteócitos.

A superfície cementária mostra-se uniforme, regular e revestida por cementoblastos justapostos e ao acaso, alguns em paliçada. Não se observam lacunas de reabsorção.

No ligamento periodontal, nota-se espessura levemente aumentada, principalmente na região mais cervical. Há numerosos fibroblastos, distribuídos principalmente em fascículos e sem alteração nuclear. As fibras colágenas 
encontram-se estiradas e há discretas áreas hialinas. Notam-se poucos vasos sangüíneos, colabados e dilatados, com discreta hiperemia. Não há infiltrado inflamatório.

4 - Área de tensão inter-radicular na raiz mesiovestibular na região cervical

A superfície óssea periodontal apresenta-se irregular, recortada, com linhas de reversão e revestida por osteoblastos justapostos ora em paliçada, ora ao acaso. Não se observam lacunas de reabsorção e há clastos localizados a distância. Na superfície endosteal notam-se espaços medulares, muitos osteócitos e linhas de reversão.

A superfície cementária mostra-se uniforme e revestida por cementoblastos justapostos, em paliçada e ao acaso, não ocorrendo lacunas de reabsorção.

O ligamento periodontal apresenta espessura uniforme e regular, bastante celularizado, com fibroblastos fusiformes e ovalados, e alguns com núcleo picnótico. As fibras colágenas encontram-se levemente estiradas e perpendiculares às superfícies óssea e cementária. Os vasos sangüíneos ocorrem em pequena quantidade, mostram-se dilatados e hiperêmicos e colabados. Não há infiltrado inflamatório.

As figuras 4, 5, 6 e 7 representam fotomicrografias ilustrativas de fenômenos observados nas áreas correspondentes à pressão e tensão nos animais do Grupo C. 


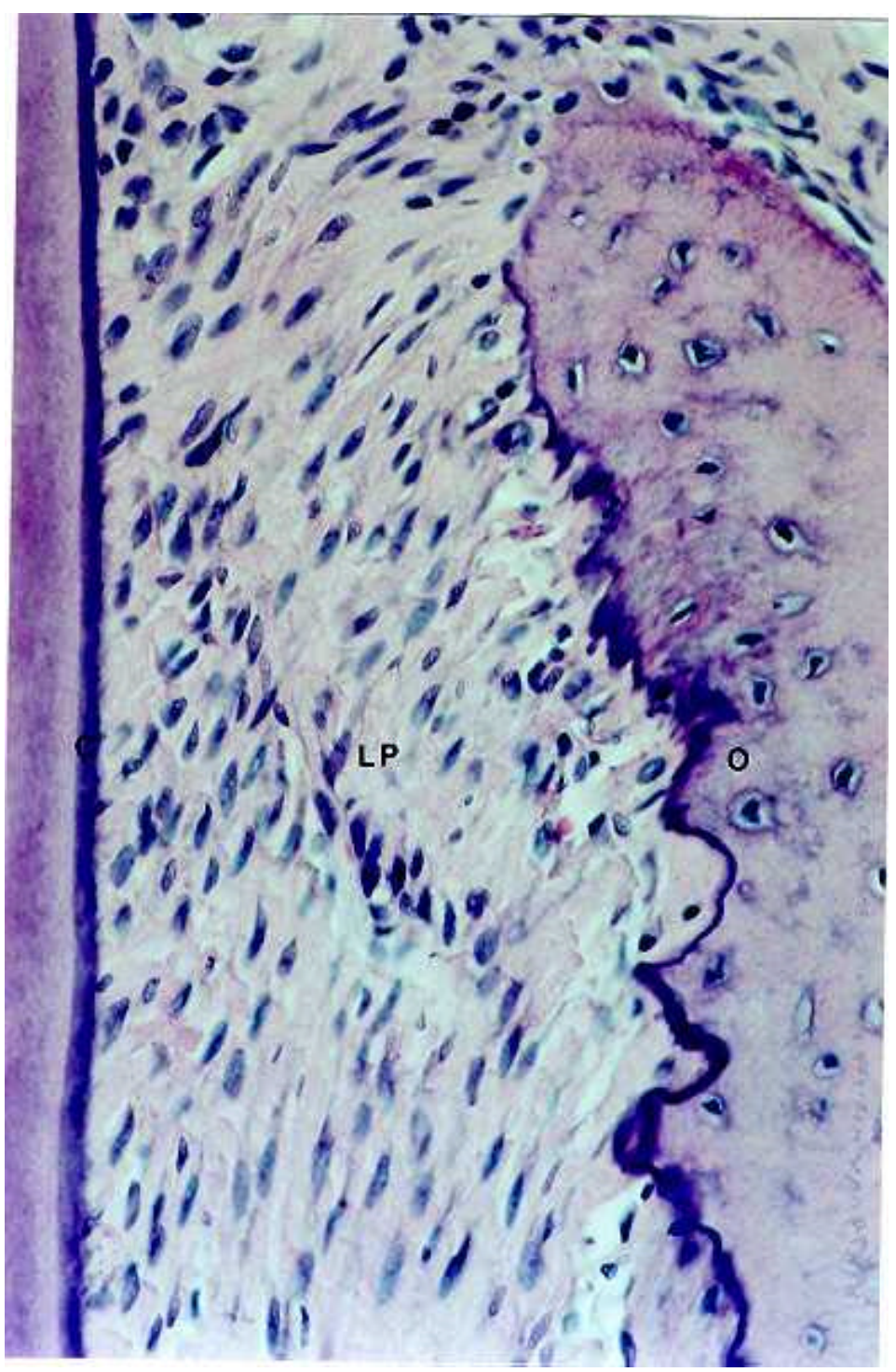

FIGURA 4 - Região cervical do lado mesial da raiz mesiovestibular, correspondente à área de pressão externa nos animais do Grupo $\mathbf{C}$. Nota-se ligamento periodontal ricamente celularizado; superfície óssea periodontal recortada, parcialmente revestida por osteoblastos, com linha de reversão e sem lacunas de reabsorção e com crista alveolar arredondada; superfície cementária uniforme e revestida por cementoblastos e sem lacunas de reabsorção. (Coloração HE; objetiva: 40x). C = cemento; $\mathrm{O}=$ osso; $\mathrm{LP}=$ ligamento periodontal 


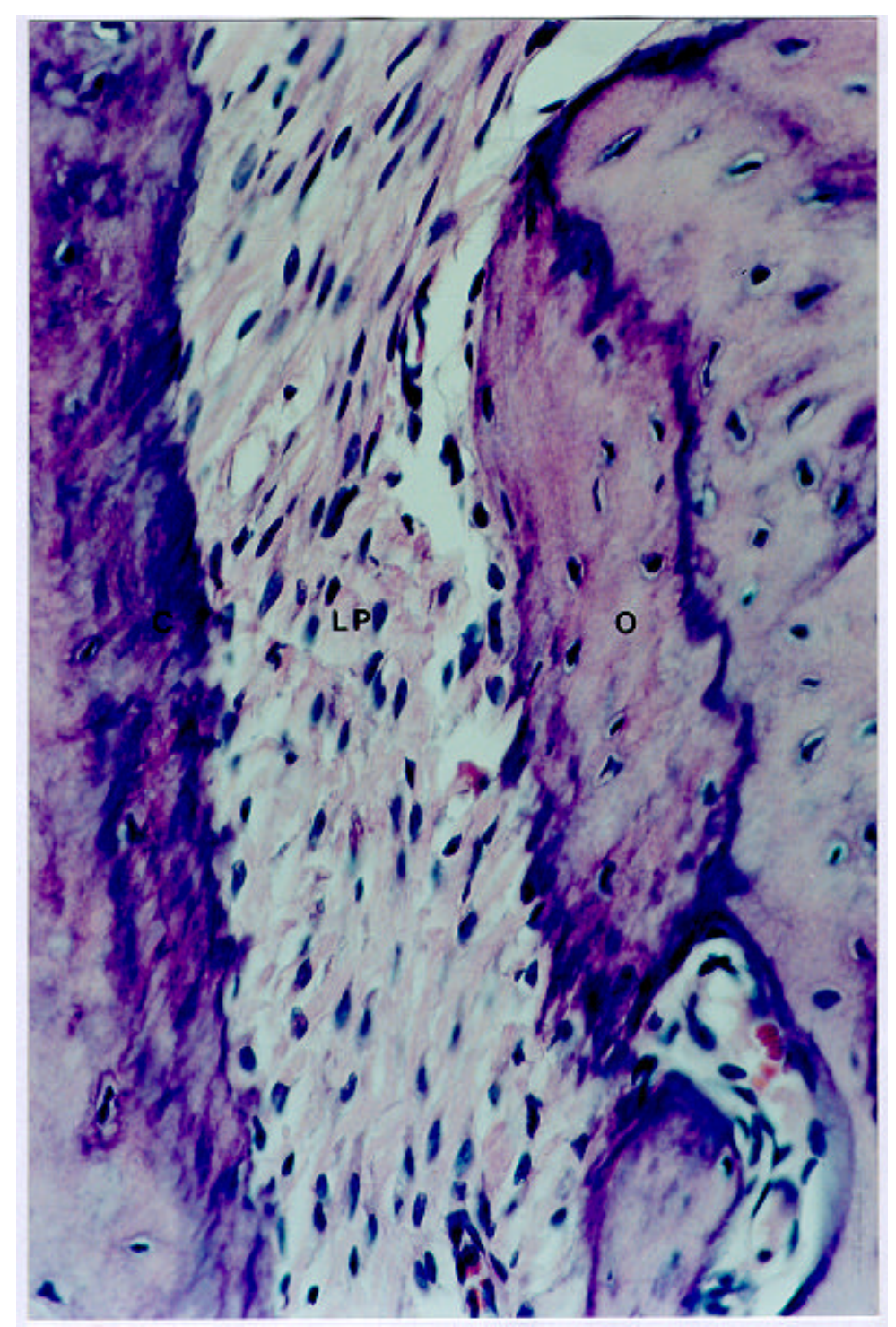

FIGURA 5 - Região cervical do lado mesial da raiz distovestibular, correspondente à área de pressão inter-radicular nos animais do Grupo C. Nota-se ligamento periodontal com fibroblastos dispostos ora em fascículos, ora ao acaso e alguns vasos sangüíneos; superfície óssea periodontal uniforme, parcialmente revestida por osteoblastos, com linha de reversão e sem lacunas de reabsorção; superfície cementária uniforme e revestida parcialmente por cementoblastos e sem lacunas de reabsorção. (Coloração HE; objetiva: 40x). C = cemento; $O=$ osso; LP = ligamento periodontal. 


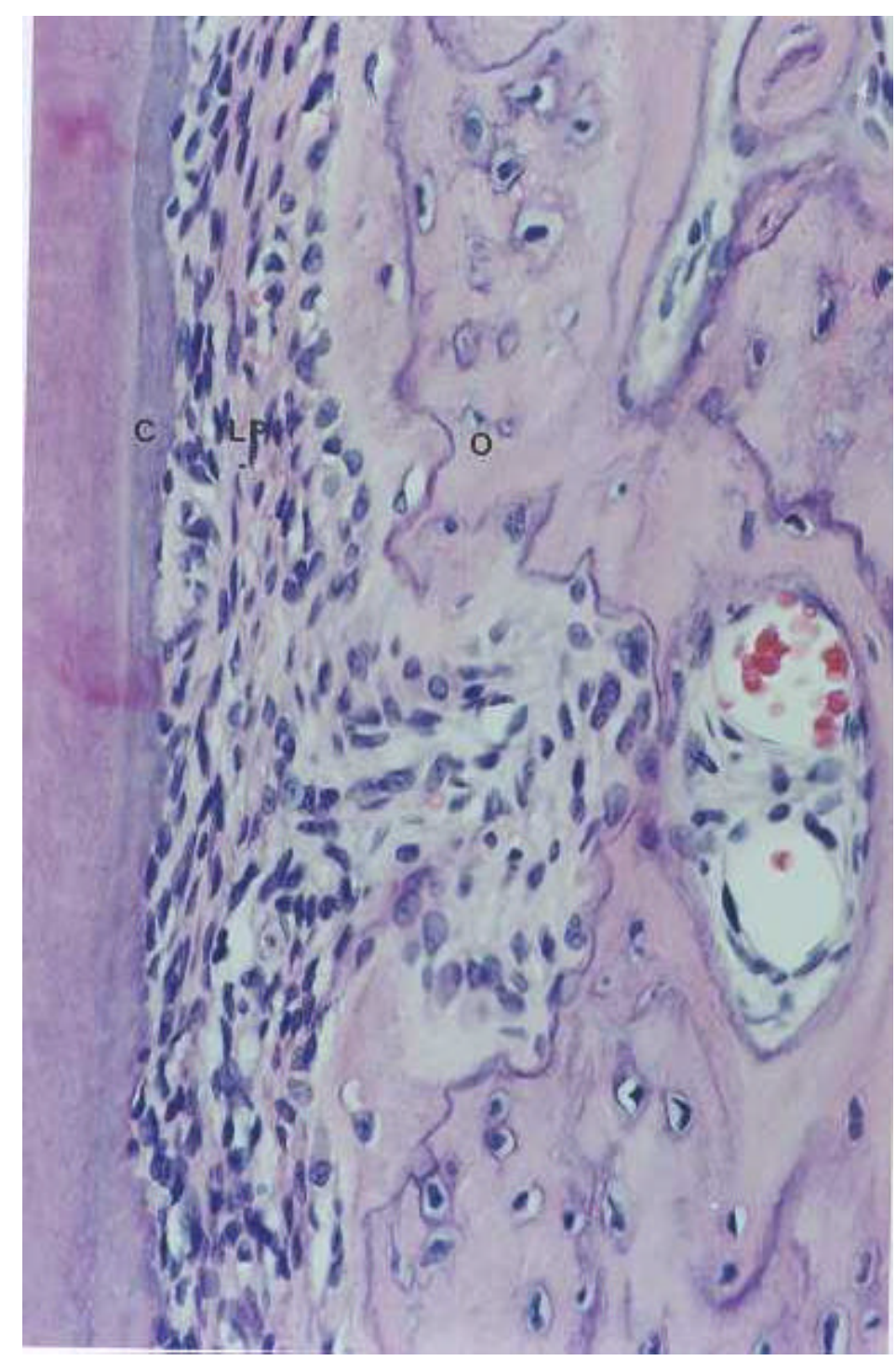

Figura 6 - Região cervical do lado distal da raiz mesiovestibular, correspondente à área de tensão inter-radicular nos animais do Grupo C. Notase ligamento periodontal com muitos fibroblastos dispostos desorganizada-mente; superfície óssea periodontal recortada, revestida por osteoblastos, com linha de reversão, com osteóide, sem lacunas de reabsorção e com espaços medulares amplos; superfície cementária uniforme e revestida por cementoblastos e sem lacunas de reabsorção. (Coloração HE; objetiva: 40x). C = cemento; $\mathrm{O}=$ osso; $L P=$ ligamento periodontal. 


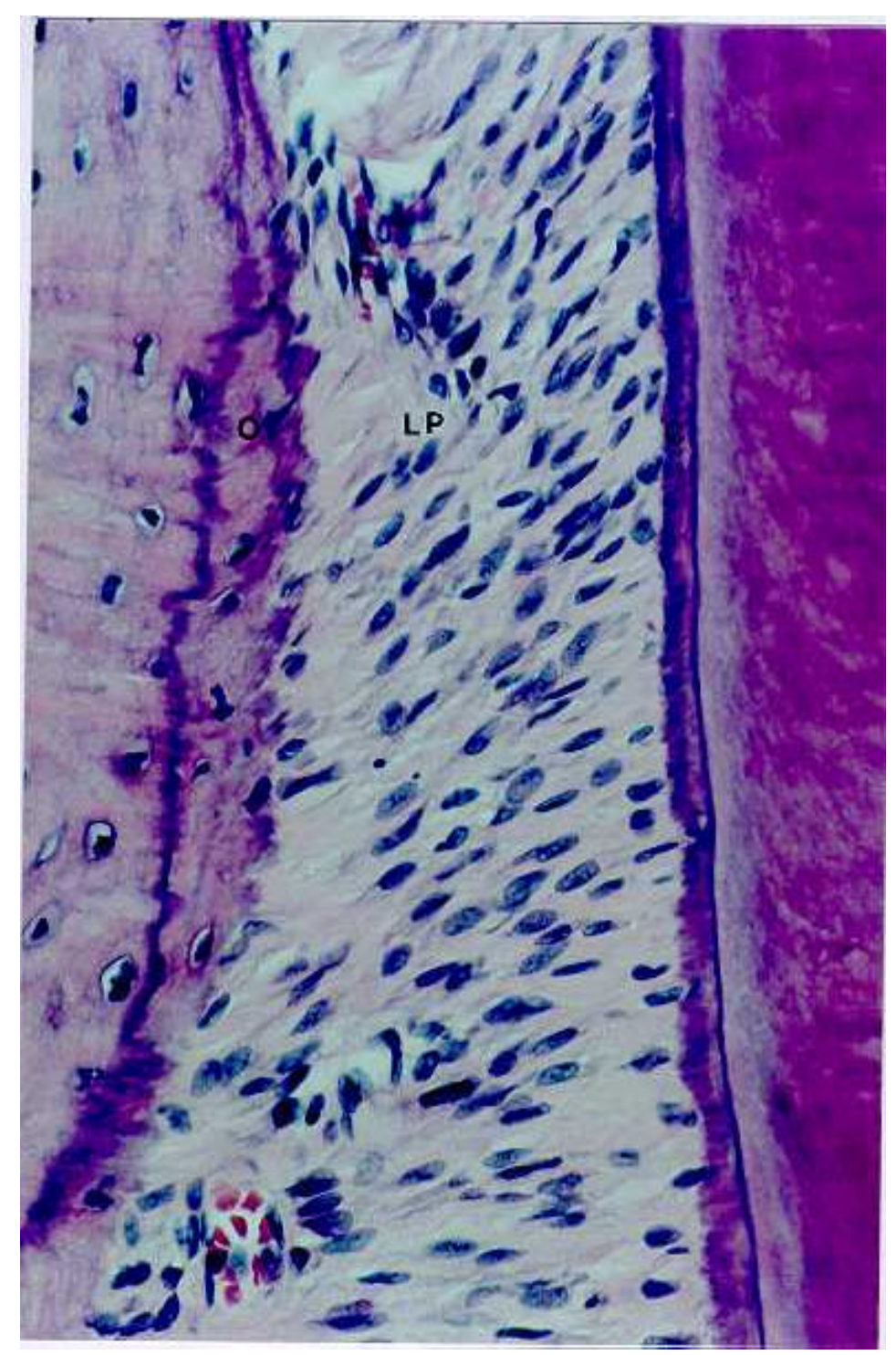

Figura 7 - Região cervical do lado distal da raiz distovestibular, correspondente à área de tensão externa nos animais do Grupo C. Nota-se ligamento periodontal ricamente celularizado, com fibroblastos fusiformes e fasciculados e alguns vasos sangüíneos; superfície óssea periodontal uniforme, revestida por osteoblastos, com linha de reversão e sem lacunas de reabsorção; superfície cementária uniforme e revestida por cementoblastos e sem lacunas de reabsorção. (Coloração HE; objetiva: 40x). C = cemento; O = osso; LP = ligamento periodontal. 


\section{GRUPO MD 1}

O grupo MD 1 corresponde aos animais com 91 dias de idade, com movimentação dentária por 24 horas e sem ovariectomia.

1 - Área de pressão externa na raiz mesiovestibular na região cervical

No tecido ósseo, nota-se a crista óssea alveolar arredondada e a superfície periodontal levemente recortada, sem lacunas de reabsorção e com clastos a distância; está revestida por osteoblastos justapostos e ao acaso e há discretas linhas de reversão. A porção endosteal contém poucos espaços medulares e poucos osteócitos.

A superfície cementária mostra-se uniforme, sem lacunas de reabsorção e está revestida por cementoblastos dispostos em paliçada e ao acaso, com alguns mostrando núcleo picnótico.

O ligamento periodontal apresenta espessura uniforme e discreto estreitamento na região mais cervical. Mostra-se bastante celularizado, com fibroblastos fusiformes, ovalados e dispostos ao acaso, e alguns com núcleo picnótico. As fibras colágenas dispõem-se desorganizadamente e não há áreas hialinas. Os vasos sangüíneos estão dilatados e hiperêmicos. Não são notados infiltrado inflamatório e restos epiteliais odontogênicos.

2 - Área de pressão inter-radicular na raiz distovestibular na região cervical

O tecido ósseo mostra superfície periodontal regular, sem lacunas de reabsorção e com alguns clastos a distância. Está revestida parcialmente por osteoblastos justapostos e não apresenta linhas de reversão. Na superfície endosteal há poucos espaços medulares e nota-se reabsorção óssea a distância, com clastos em lacunas e justapostos. 
A superfície cementária mostra-se regular e uniforme, revestida parcialmente por cementoblastos, alguns com núcleos picnóticos. A ausência de cementoblastos coincide com áreas hialinas no ligamento periodontal e não há lacunas de reabsorção cementária.

O ligamento periodontal mostra-se estreitado, com pequenas áreas hialinas e de anquilose dentoalveolar. Nota-se pouca celularidade, com fibroblastos ovalados e geralmente picnóticos. Os feixes de fibras colágenas dispõem-se desorganizadamente. Os vasos sangüíneos estão dilatados e hiperêmicos e localizam-se principalmente em redor da área hialina. Nota-se discreto infiltrado inflamatório mononuclear.

3 - Área de tensão externa na raiz distovestibular na região cervical

A superfície óssea periodontal mostra-se recortada, com discretas linhas de reversão, com lacunas de reabsorção com clastos em lacunas e justapostos, principalmente a partir do terço médio em direção ao terço apical. A superfície óssea periodontal está revestida parcialmente por osteoblastos, justapostos e ao acaso. A superfície óssea endosteal não contém espaços medulares e lacunas de reabsorção.

A superfície cementária mostra-se com superfície uniforme, sem reabsorção e está revestida por cementoblastos justapostos e em paliçada.

O ligamento periodontal é regular e mostra-se levemente mais espesso, contendo muitos fibroblastos fusiformes e ovalados, em fascículos e ao acaso e alguns com núcleo picnótico. As fibras colágenas mostram-se distendidas e há discretas áreas hialinas. Os vasos sangüíneos estão dilatados e hiperêmicos. Há discreto infiltrado inflamatório mononuclear; e acima da crista óssea alveolar notam-se neutrófilos.

4 - Área de tensão inter-radicular na raiz mesiovestibular na região cervical

O tecido ósseo mostra superfície periodontal recortada, com poucas linhas de reversão e com discretas lacunas de reabsorção, com clastos dispostos 
a distância. Mostra-se parcialmente revestida por osteoblastos justapostos, em paliçada e ao acaso. Na superfície endosteal há amplos espaços medulares e proeminentes linhas de reversão.

A superfície cementária apresenta-se uniforme e revestida por cementoblastos justapostos e em paliçada, e não há lacunas de reabsorção.

O ligamento periodontal mantém-se com espessura normal e constante, e bastante celularizado, com fibroblastos fusiformes e às vezes ovalados, alguns com núcleos picnóticos e distribuídos em fascículos. As fibras colágenas distribuem-se perpendicularmente e estão levemente distendidas. Há discretas e poucas áreas hialinas. Os vasos sangüíneos ocorrem em pequena quantidade e estão predominantemente colabados e não se observa infiltrado inflamatório.

As figuras 8, 9, 10 e 11 representam fotomicrografias ilustrativas de fenômenos observados nas áreas correspondentes à pressão e tensão nos animais do Grupo MD 1. 


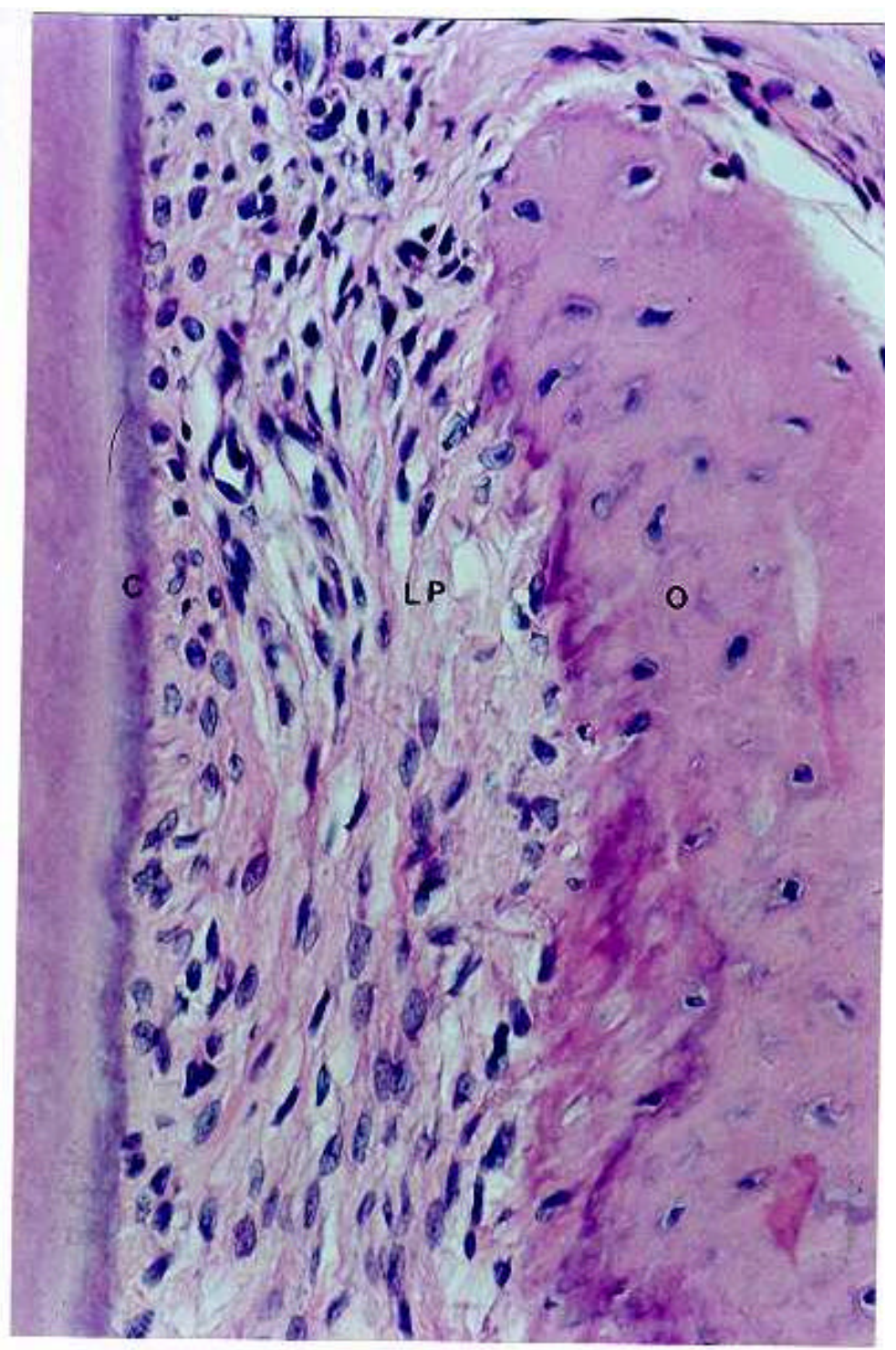

FIGURA 8 - Região cervical do lado mesial da raiz mesiovestibular, referente à área de pressão externa nos animais do Grupo MD 1. Nota-se ligamento periodontal ricamente celularizado, com fibroblastos ao acaso e picnóticos; superfície óssea periodontal levemente recortada, revestida por osteoblastos, sem lacunas de reabsorção e com crista alveolar arredondada; superfície cementária uniforme e revestida por cementoblastos e sem lacunas de reabsorção. (Coloração HE; objetiva: 40x). C = cemento; $\mathrm{O}=$ osso; $\mathrm{LP}$ = ligamento periodontal. 


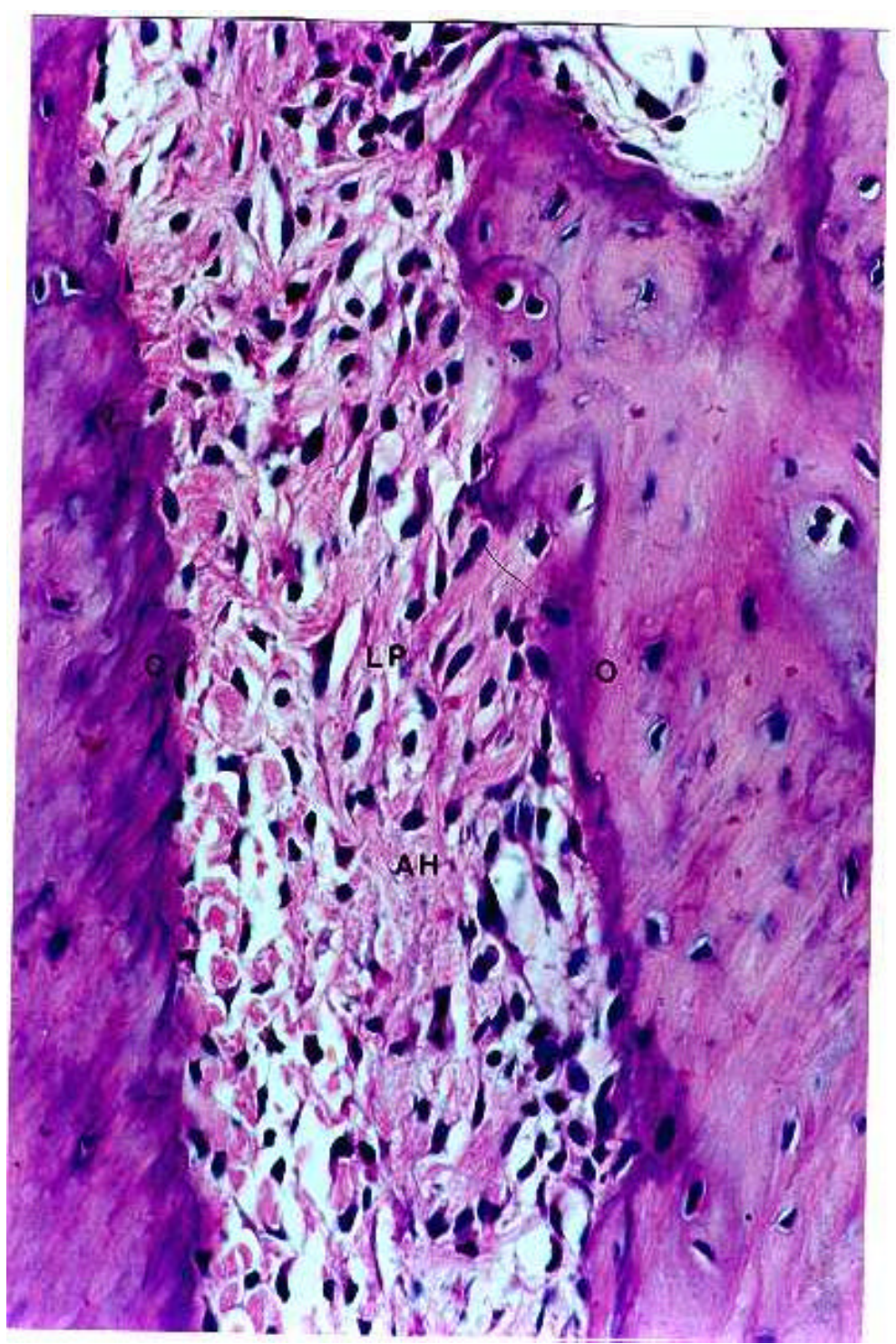

FIGURA 9 - Região cervical do lado mesial da raiz distovestibular, referente à área de pressão inter-radicular nos animais do Grupo MD 1. Nota-se ligamento periodontal com espessura levemente diminuída, com fibroblastos fusiformes, ovalados e ao acaso, com discretas áreas hialinas e alguns vasos sangüíneos dilatados; superfície óssea periodontal irregular, parcialmente revestida por osteoblastos, com discreta linha de reversão e sem lacunas de reabsorção; superfície cementária uniforme e revestida por cementoblastos e sem lacunas de reabsorção. (Coloração HE; objetiva: 40x). C = cemento; $\mathrm{O}=$ osso; $\mathrm{LP}=$ ligamento periodontal; $\mathrm{AH}$ = área hialina . 


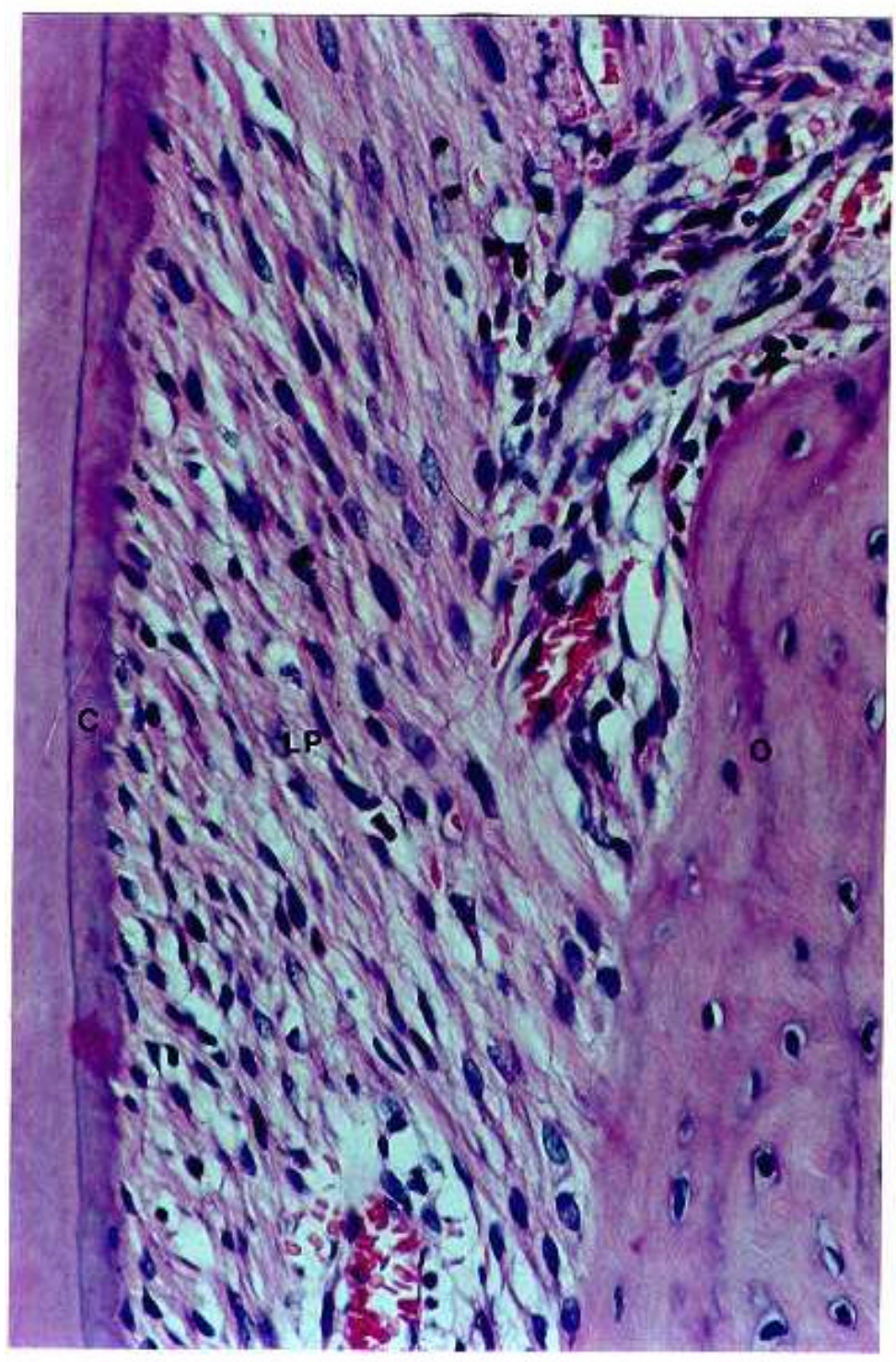

Figura 10 - Região cervical do lado distal da raiz mesiovestibular, referente à área de tensão inter-radicular nos animais do Grupo MD 1. Nota-se ligamento periodontal com ricamente celularizado e com vasos sangüíneos dilatados e hiperêmicos; superfície óssea periodontal uniforme, revestida por osteoblastos, com osteóide e sem lacunas de reabsorção; superfície cementária uniforme e revestida por cementoblastos e sem lacunas de reabsorção. (Coloração HE; objetiva: 40x). C = cemento; $\mathrm{O}=$ osso; LP = ligamento periodontal. 


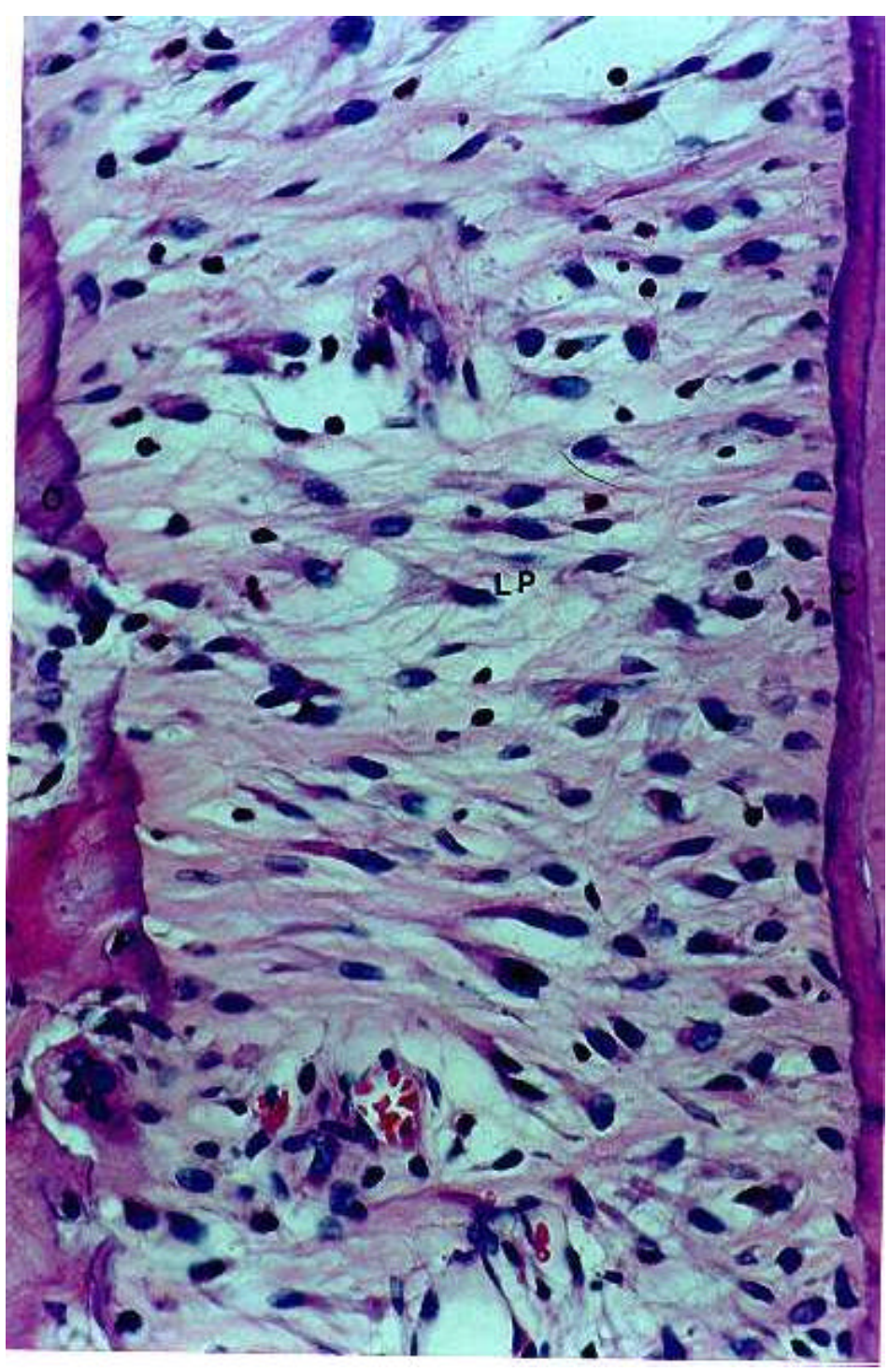

Figura 11 - Região cervical do lado distal da raiz distovestibular, referente à área de tensão externa nos animais do Grupo MD 1. Notase ligamento periodontal com espessura aumentada, com fibroblastos fusiformes e picnóticos e vasos sangüíneos dilatados, alguns hiperêmicos; superfície óssea periodontal recortada, revestida parcialmente por osteoblastos, com uma lacuna de reabsorção com clasto em seu interior; superfície cementária uniforme e revestida por cementoblastos e sem lacunas de reabsorção. (Coloração HE; objetiva: 40x). $\mathrm{C}=$ cemento; $\mathrm{O}=$ osso; $\mathrm{LP}=$ ligamento periodontal. 


\section{GRUPO MD 3}

O grupo MD 3 corresponde aos animais com 93 dias de idade, com movimentação dentária por três dias e sem ovariectomia.

1 - Área de pressão externa na raiz mesiovestibular na região cervical

A superfície óssea periodontal mostra-se bastante recortada e irregular, com a crista óssea afilada. Está revestida parcialmente por osteoblastos justapostos e a distância. São notadas linhas de reversão e lacunas de reabsorção, com clastos justapostos e em lacunas. Na superfície óssea endosteal há poucos espaços medulares.

A superfície cementária apresenta-se uniforme, plana, sem lacunas de reabsorção e está revestida por cementoblastos justapostos e ao acaso.

O ligamento periodontal apresenta espessura normal e constante, é bastante celularizado, com fibroblastos fusiformes, ovalados e alguns com núcleo picnótico e distribuindo-se em fascículos. As fibras colágenas mostram-se distintas e perpendiculares ao osso e ao cemento e há discretas áreas hialinas. Os vasos sangüíneos são pouco evidentes e predominantemente colabados e não há infiltrado inflamatório.

2 - Área de pressão inter-radicular na raiz distovestibular na região cervical

O tecido ósseo mostra superfície periodontal levemente recortada, com linhas de reversão tênues e revestida por osteoblastos justapostos e ao acaso. Há poucas lacunas de reabsorção e os clastos dispõem-se a distância e justapostos. A superfície endosteal mostra amplos espaços medulares e lacunas de reabsorção.

A superfície cementária mostra-se uniforme e regular, não ocorrendo lacunas de reabsorção. Os cementoblastos distribuem-se justapostos, ao acaso e parcialmente sobre a superfície cementária.

O ligamento periodontal mostra-se estreito e levemente irregular. As fibras colágenas estão desorganizadas e os fibroblastos são fusiformes e ovalados, alguns com núcleo picnótico e distribuídos ao acaso. Ocorrem poucas e 
discretas áreas hialinas e os vasos sangüíneos estão colabados, notando-se poucos dilatados e hiperêmicos, além de pequenas áreas de edema. Há discreto infiltrado inflamatório mononuclear.

3 - Área de tensão externa na raiz distovestibular na região cervical

A superfície óssea periodontal mostra-se recortada, revestida por osteoblastos justapostos e ao acaso. Não são notadas linhas de reversão e há lacunas de reabsorção e clastos dispostos a distância. Não ocorrem espaços medulares na superfície óssea endosteal.

A superfície cementária apresenta-se uniforme e regular, revestida por cementoblastos justapostos e ao acaso. Não há lacunas de reabsorção.

O ligamento periodontal mostra espessura aumentada, com fibras colágenas distribuídas irregularmente, entremeadas por fibroblastos fusiformes e ovalados, alguns com núcleo picnótico e não ocorrem áreas hialinas. Há vasos sangüíneos dilatados e hiperêmicos e áreas de edema; além de discreto infiltrado inflamatório mononuclear, com polimorfonucleares na região acima da crista óssea alveolar.

4 - Área de tensão inter-radicular na raiz mesiovestibular na região cervical

A superfície óssea periodontal mostra-se levemente recortada e irregular, com linhas de reversão e pequena quantidade de osteóide. Os osteoblastos localizam-se justapostos e ao acaso e revestem-na parcialmente. Há discretas lacunas de reabsorção com clastos dispostos a distância. Na superfície óssea endosteal há amplos espaços medulares.

A superfície cementária apresenta-se levemente irregular, sem lacunas de reabsorção, e está revestida por cementoblastos justapostos em paliçada e a distância.

O ligamento periodontal mostra-se com espessura uniforme, com fibras colágenas estiradas e perpendiculares ao osso e ao cemento e com discretas áreas hialinas. Notam-se muitos fibroblastos fusiformes, ovalados, e organizados ora em fascículos, ora ao acaso, estando alguns em picnose. Os 
vasos sangüíneos ocorrem em pequena quantidade e estão dilatados e hiperêmicos. Não se observa infiltrado inflamatório.

As figuras 12, 13, 14 e 15 representam fotomicrografias ilustrativas de fenômenos observados nas áreas correspondentes à pressão e tensão nos animais do Grupo MD 3. 


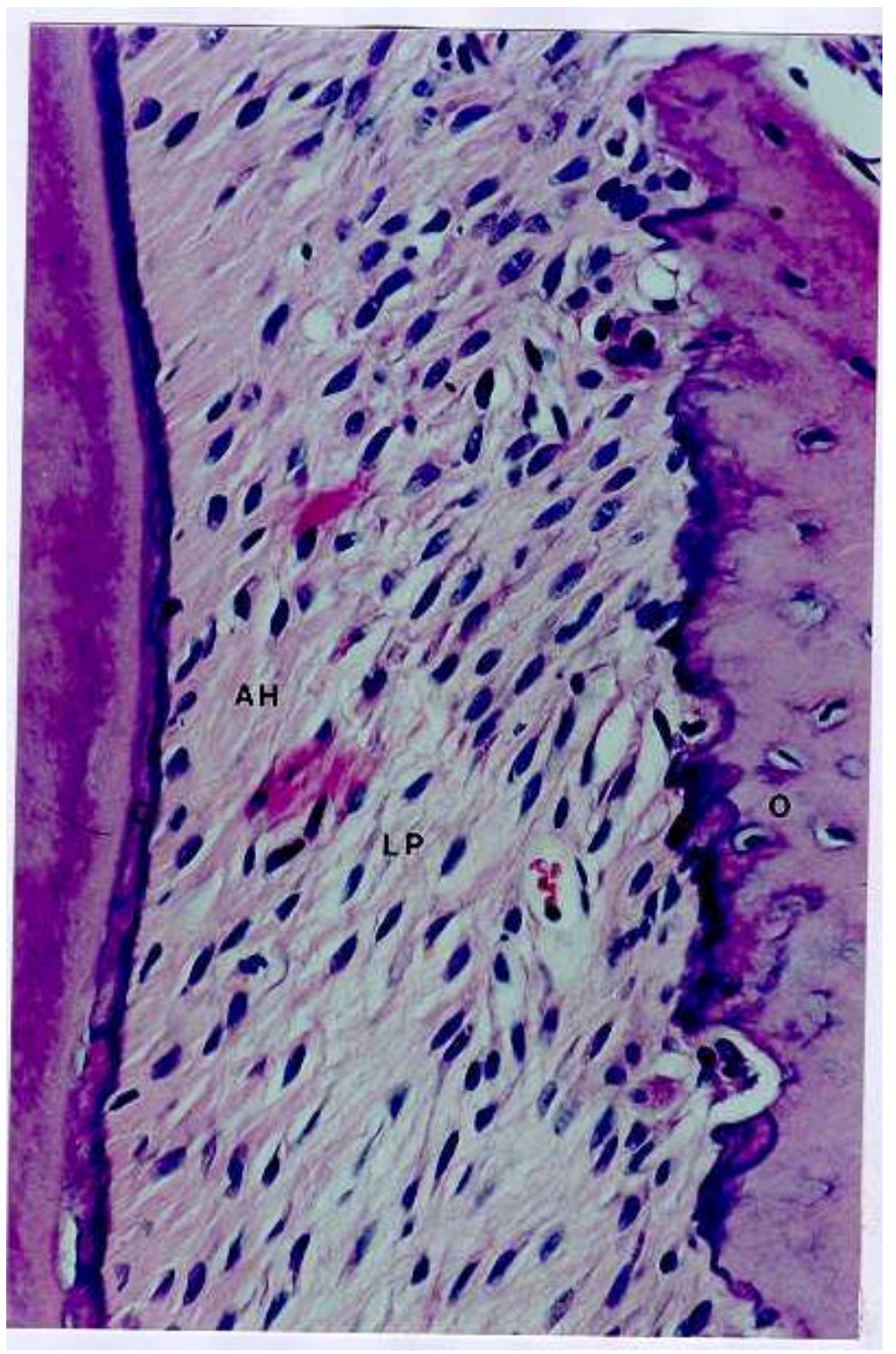

FIGURA 12 - Região cervical do lado mesial da raiz mesiovestibular, referente à área de pressão externa nos animais do Grupo MD 3. Nota-se ligamento periodontal ricamente celularizado, com fibroblastos fasciculados e ao acaso e com discretas áreas hialinas; superfície óssea periodontal recortada, revestida parcialmente por osteoblastos, com linhas de reversão, com lacunas de reabsorção e clastos em seu interior e com crista alveolar levemente afilada; superfície cementária uniforme e revestida parcialmente por cementoblastos e sem lacunas de reabsorção. (Coloração HE; objetiva: 40x). C = cemento; $\mathrm{O}=$ osso; LP = ligamento periodontal; $\mathrm{AH}=$ área hialina. 


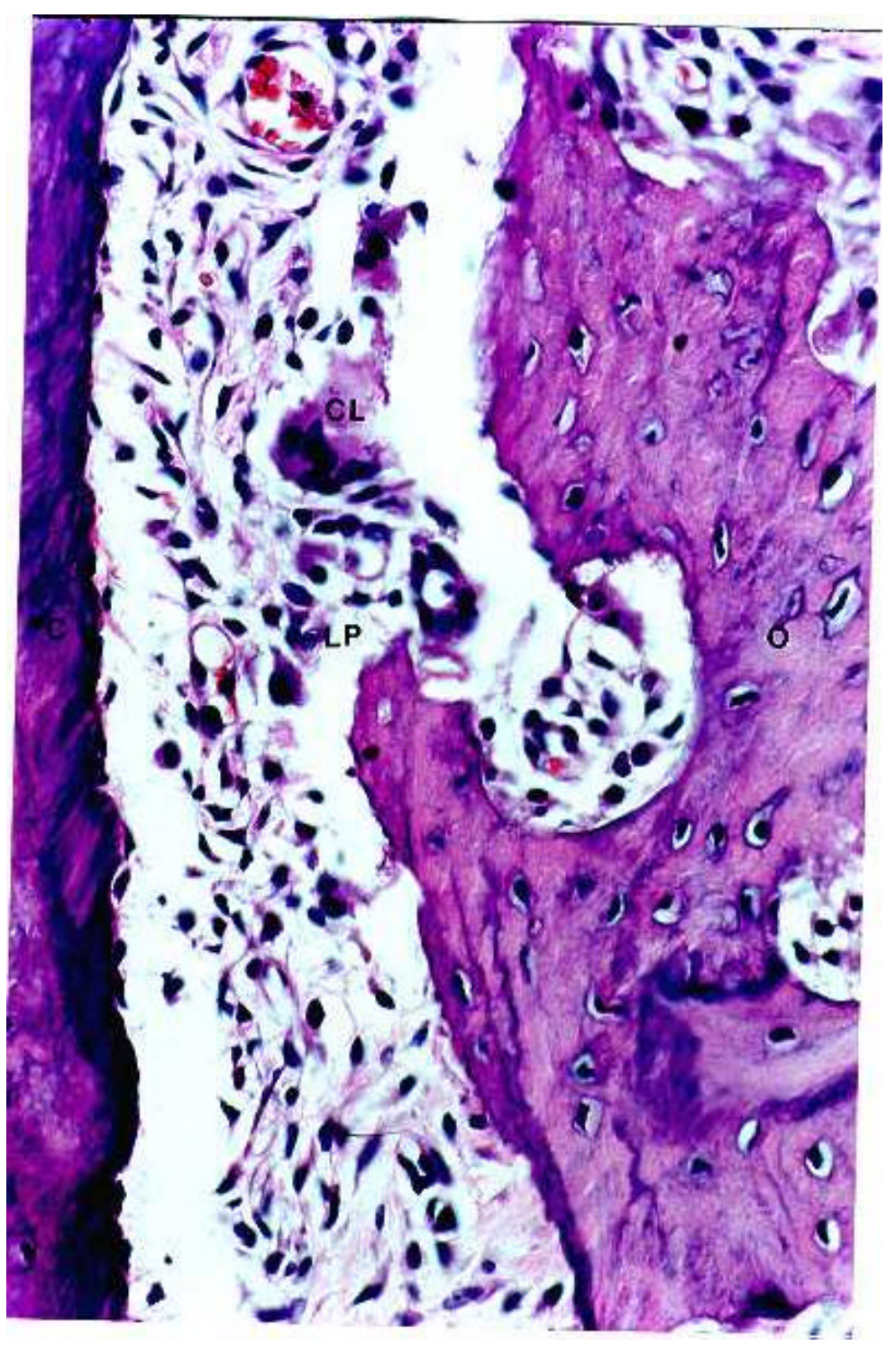

FIGURA 13 - Região cervical do lado mesial da raiz distovestibular, referente à área de pressão inter-radicular nos animais do Grupo MD 3. Nota-se ligamento periodontal com espessura diminuída, com fibroblastos amorfos, ao acaso e picnóticos, com vasos sangüíneos e edema; superfície óssea periodontal irregular, parcialmente revestida por osteoblastos, com lacuna de reabsorção e clastos a distância; superfície cementária uniforme e revestida parcialmente por cementoblastos, alguns picnóticos e sem lacunas de reabsorção. (Coloração HE; objetiva: 40x). $\mathrm{C}=$ cemento; $\mathrm{O}=$ osso; $\mathrm{LP}=$ ligamento periodontal; $\mathrm{CL}=$ clasto. 


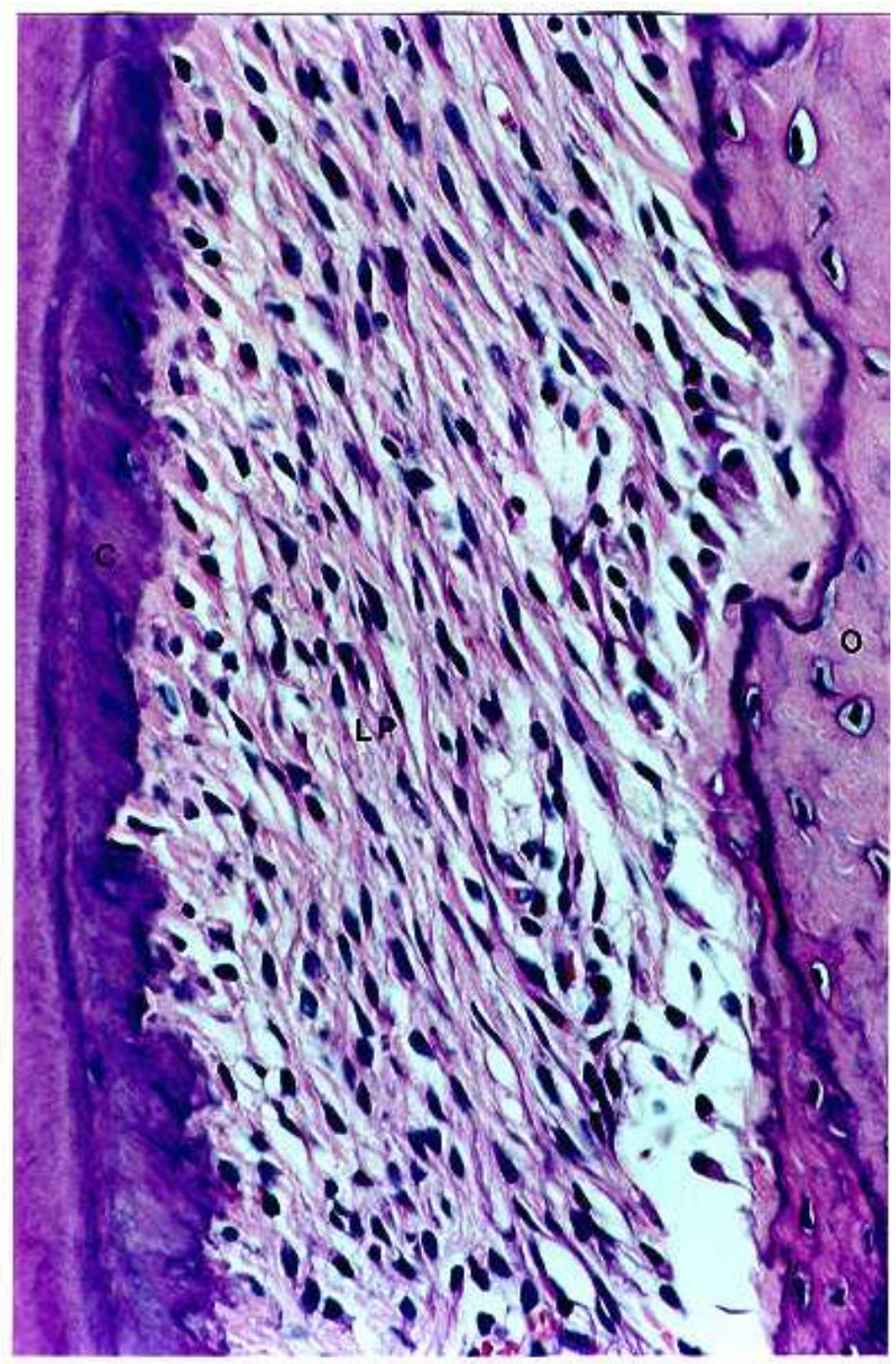

Figura 14 - Região cervical do lado distal da raiz mesiovestibular, referente à área de tensão inter-radicular nos animais do Grupo MD 3. Nota-se ligamento periodontal com muitos fibroblastos fusiformes e fasciculados, alguns picnóticos e com discreta vascularização; superfície óssea periodontal irregular, revestida parcialmente por osteoblastos, com linha de reversão e osteóide e sem lacunas de reabsorção; superfície cementária levemente irregular e revestida por cementoblastos e sem lacunas de reabsorção. (Coloração HE; objetiva: 40x). $\mathrm{C}=$ cemento; $\mathrm{O}=$ osso; $L P=$ ligamento periodontal. 


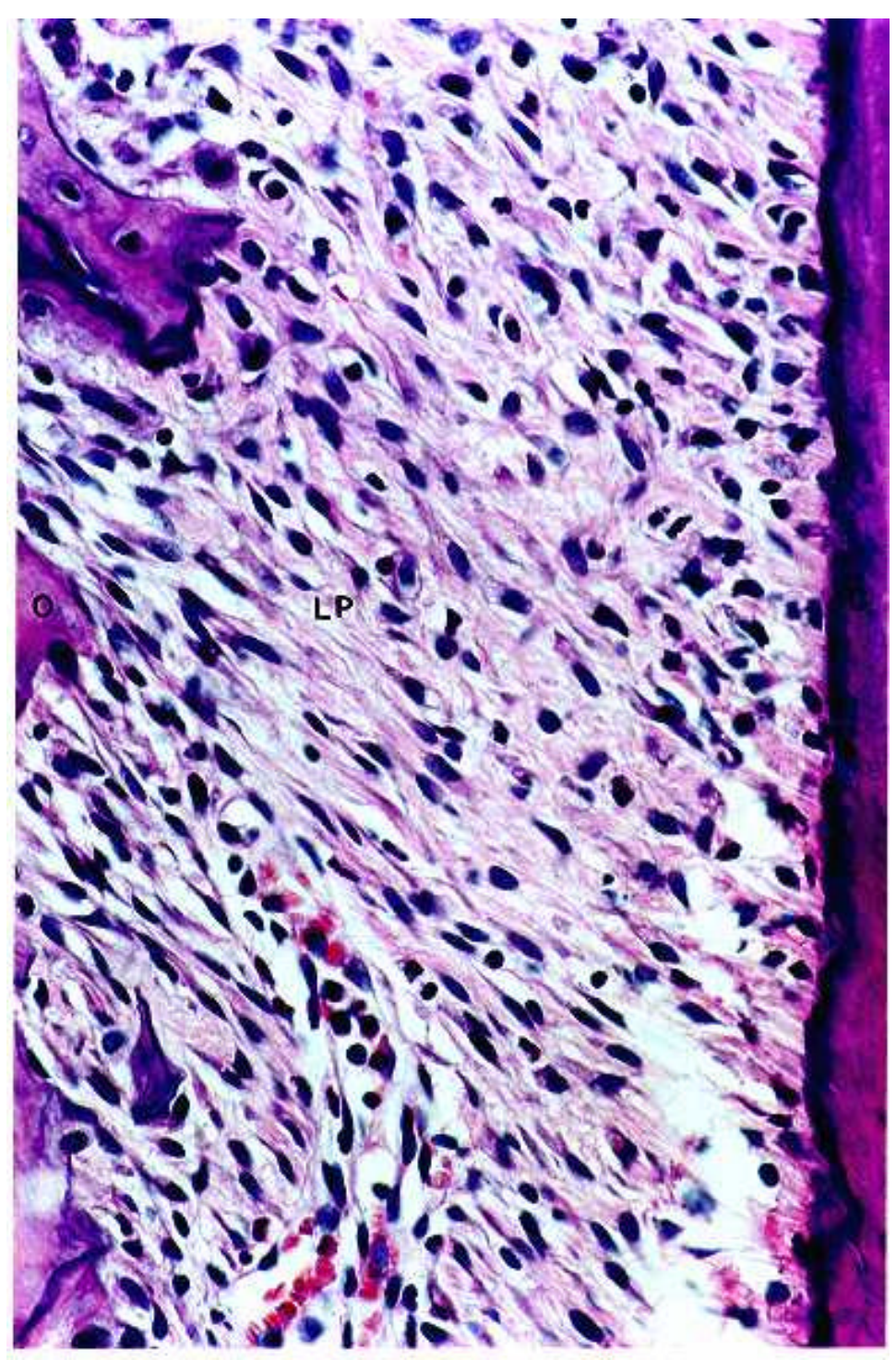

Figura 15 - Região cervical do lado distal da raiz distovestibular, referente à área de tensão externa nos animais do Grupo MD 3 Notase ligamento periodontal com espessura aumentada, com fibroblastos fusiformes, ovalados e ao acaso e vasos sangüíneos dilatados e hiperêmicos; superfície óssea periodontal recortada, revestida parcialmente por osteoblastos; superfície cementária uniforme e revestida por cementoblastos, alguns picnóticos e sem lacunas de reabsorção. (Coloração HE; objetiva: 40x). C = cemento; $\mathrm{O}=$ osso; $\mathrm{LP}=$ ligamento periodontal. 


\section{GRUPO MD 5}

O grupo MD 5 corresponde aos animais com 95 dias de idade, com movimentação dentária por cinco dias e sem ovariectomia.

1 - Área de pressão externa na raiz mesiovestibular na região cervical

Nota-se crista óssea alveolar irregular, pontiaguda e com lacuna de reabsorção. A superfície óssea periodontal mostra-se bastante recortada, com lacunas de reabsorção com clastos em seu interior e a distância; há linha de reversão contínua, e revestimento por osteoblastos justapostos e ao acaso, notando-se osteóide. A porção óssea endosteal não contém espaços medulares e há poucos osteócitos.

A superfície cementária apresenta-se uniforme, com cementóide e revestida parcialmente por cementoblastos justapostos e ao acaso. Não são notadas lacunas de reabsorção.

O ligamento periodontal mostra espessura uniforme e normal, é bastante celularizado, com fibroblastos dispostos em fascículos, sendo fusiformes e ovalados; e alguns possuem núcleo picnótico. As fibras colágenas dispõem-se ora ao acaso, ora perpendiculares e não ocorrem áreas hialinas. Os vasos sangüíneos estão dilatados e hiperêmicos e há discreto infiltrado inflamatório mononuclear.

2 - Área de pressão inter-radicular na raiz distovestibular na região cervical

A superfície óssea periodontal mostra-se irregular e revestida parcialmente por osteoblastos justapostos e ao acaso, mostrando lacunas de reabsorção e clastos a distância e justapostos. Na superfície óssea endosteal nota-se intensa reabsorção a distância e nos espaços medulares, com clastos em lacunas e justapostos. Notam-se linhas de reversão em ambas as superfícies ósseas.

A superfície cementária mostra-se uniforme, regular e parcialmente revestida por cementoblastos, tendo alguns o núcleo picnótico, e localização justaposta e ao acaso. Não são notadas lacunas de reabsorção. 
O ligamento periodontal mostra espessura levemente diminuída, está bastante celularizado, com áreas hialinas e anquilose dentoalveolar. Os fibroblastos são fusiformes e ovalados, distribuídos aleatoriamente, e com núcleos picnóticos. Os vasos sangüíneos estão ora dilatados e hiperêmicos, ora colabados. Há infiltrado inflamatório mononuclear, principalmente junto às áreas hialinas.

3 - Área de tensão externa na raiz distovestibular na região cervical

A superfície óssea periodontal mostra-se irregular e recortada, revestida por osteoblastos justapostos, em paliçada e ao acaso, e não há lacunas de reabsorção. Na face endosteal há poucos espaços medulares.

A superfície cementária mostra-se uniforme e revestida por cementoblastos justapostos, ao acaso e em paliçada. Não ocorrem lacunas de reabsorção.

O ligamento periodontal mostra espessura normal, com fibroblastos fusiformes e ovalados, alguns picnóticos, e dispostos em fascículos. As fibras colágenas dispõem-se em feixes perpendiculares e há discretas áreas hialinas. Os vasos sangüíneos estão dilatados e hiperêmicos. Nota-se infiltrado inflamatório predominantemente mononuclear.

4 - Área de tensão inter-radicular na raiz mesiovestibular na região cervical

A face óssea periodontal mostra-se levemente recortada, uniforme, com discretas linhas de reversão, estando revestida por osteoblastos justapostos e ao acaso, e sem lacunas de reabsorção. $\mathrm{Na}$ face endosteal há espaços medulares amplos.

O cemento mostra-se com superfície uniforme e regular, sem lacunas de reabsorção e revestida por cementoblastos justapostos e ao acaso.

No ligamento periodontal nota-se espessura normal, com fibras colágenas distendidas e ora ao acaso, ora perpendiculares. Os fibroblastos são fusiformes e ovalados, ocorrendo alguns com núcleo picnótico. Notam-se poucas 
e pequenas áreas hialinas e os vasos sangüíneos estão colabados, dilatados e hiperêmicos. Não há infiltrado inflamatório.

As figuras 16, 17, 18 e 19 representam fotomicrografias ilustrativas de fenômenos observados nas áreas correspondentes à pressão e tensão nos animais do Grupo MD 5. 


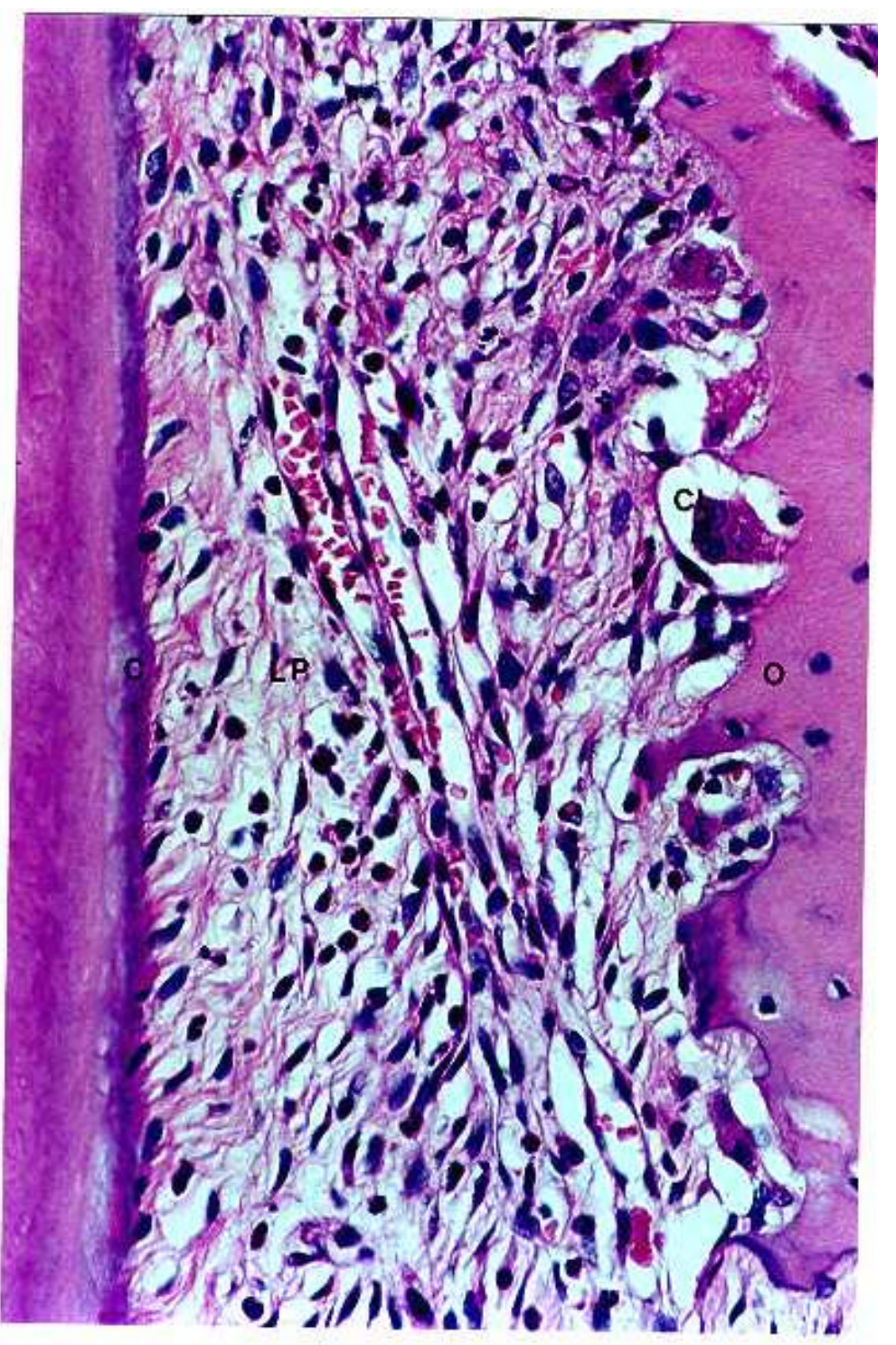

FIGURA 16 - Região cervical do lado mesial da raiz mesiovestibular, referente à área de pressão externa nos animais do Grupo MD 5 Notase ligamento periodontal com fibroblastos ovalados, alguns picnóticos e ao acaso, e com vasos sangüíneos dilatados e hiperêmicos; superfície óssea periodontal bastante recortada, revestida parcialmente por osteoblastos, com lacunas de reabsorção e clastos em seu interior e a distância e com crista alveolar afilada; superfície cementária uniforme e revestida parcialmente por cementoblastos e sem lacunas de reabsorção. (Coloração HE; objetiva: $40 \mathrm{x}$ ). $\mathrm{C}=$ cemento; $\mathrm{O}=$ osso; $\mathrm{LP}=$ ligamento periodontal; $\mathrm{CL}=$ clasto. 


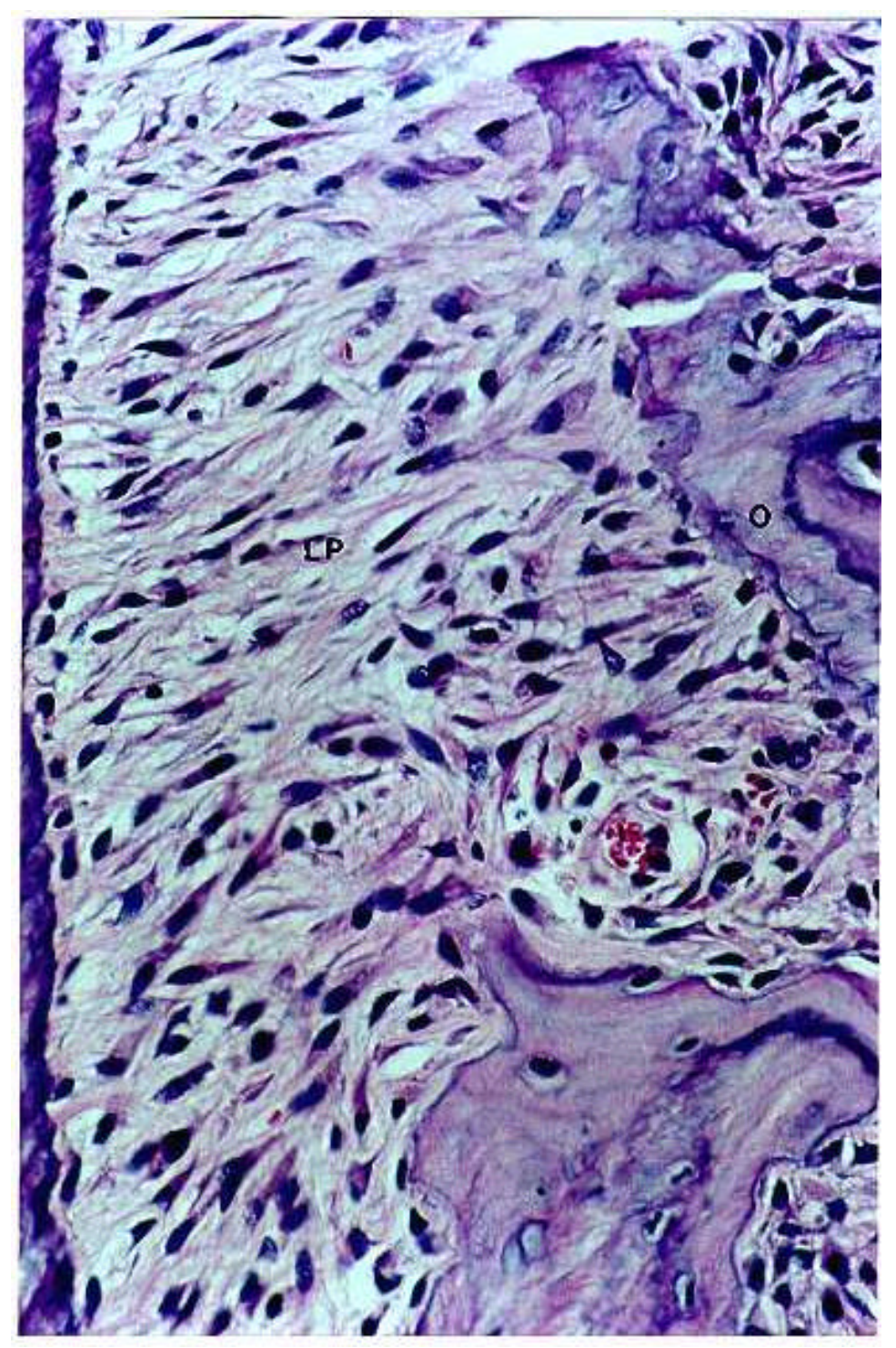

FIGURA 17 - Região cervical do lado mesial da raiz distovestibular, referente à área de pressão inter-radicular nos animais do Grupo MD 5. Nota-se ligamento periodontal com fibroblastos fusiformes e ovalados, ao acaso e picnóticos, com poucos vasos sangüíneos; superfície óssea periodontal irregular, parcialmente revestida por osteoblastos, com linhas de reversão e osteóide e sem lacunas de reabsorção; superfície cementária uniforme e revestida parcialmente por cementoblastos, vários com picnose e sem lacunas de reabsorção. (Coloração HE; objetiva: 40x). C = cemento; $\mathrm{O}=$ osso; $\mathrm{LP}=$ ligamento periodontal. 


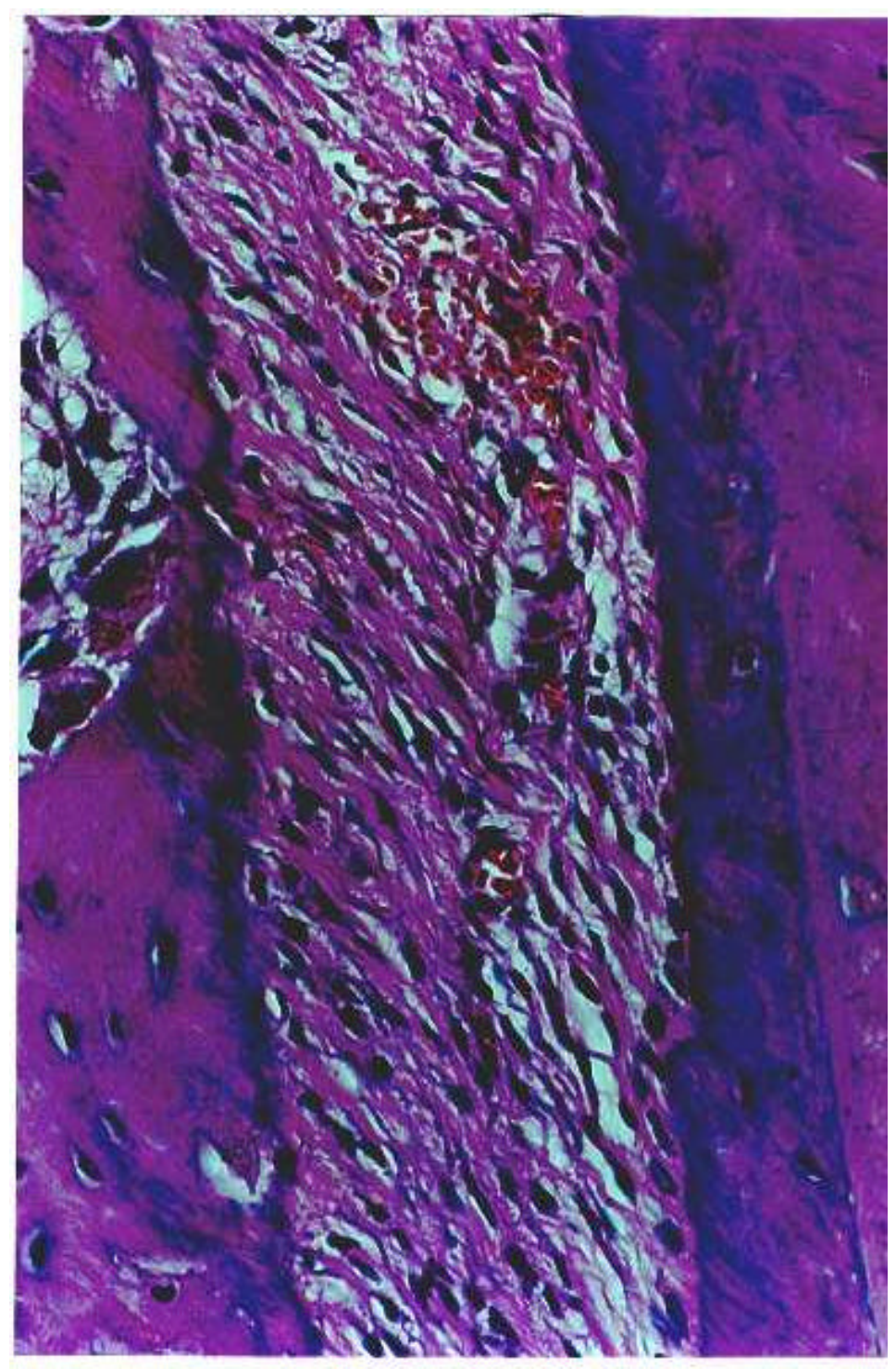

Figura 18 - Região cervical do lado distal da raiz mesiovestibular, referente à área de tensão inter-radicular nos animais do Grupo MD 5. Nota-se ligamento periodontal com muitos fibroblastos fusiformes e fasciculados, alguns picnóticos e com vasos sangüíneos dilatados e hiperêmicos; superfície óssea periodontal uniforme, revestida por osteoblastos, com osteóide e sem lacunas de reabsorção; superfície cementária uniforme e revestida por cementoblastos e sem lacunas de reabsorção. (Coloração $\mathrm{HE}$ objetiva: 40x).

C cemento; $\mathrm{O}=$ osso; $\mathrm{LP}=$ ligamento periodontal. 


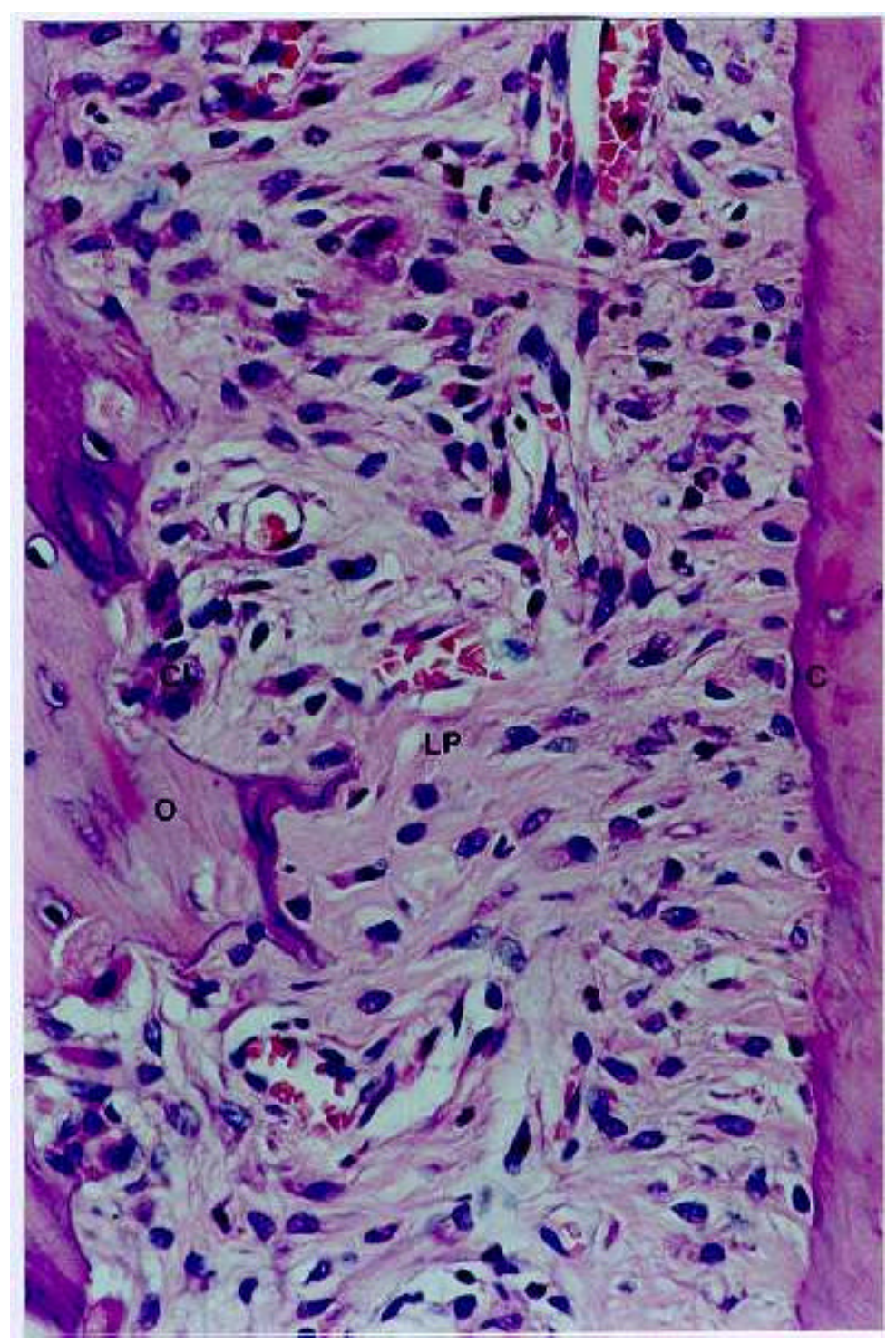

Figura 19 - Região cervical do lado distal da raiz distovestibular, referente à área de tensão externa nos animais do Grupo MD 5 Notase ligamento periodontal com espessura aumentada, com fibroblastos fusiformes, ovalados, alguns picnóticos e ao acaso e vasos sangǘneos dilatados e hiperêmicos; superfície óssea periodontal bastante recortada, revestida parcialmente por osteoblastos, com lacunas de reabsorção e clastos; superfície cementária uniforme e revestida por cementoblastos e sem lacunas de reabsorção. (Coloração HE; objetiva: 40x). C = cemento; $O=$ osso; LP = ligamento periodontal; $\mathrm{CL}=$ clasto. 


\section{GRUPO OV 1}

O grupo OV 1 corresponde aos animais com 91 dias de idade, com movimentação dentária por 24 horas após 50 dias de ovariectomia induzida.

1 - Área de pressão externa na raiz mesiovestibular na região cervical

No tecido ósseo, nota-se crista alveolar preservada e levemente recortada, sem lacunas de reabsorção. A superfície periodontal mostra-se uniforme, levemente recortada, revestida por osteoblastos justapostos e ao acaso, e com discreta linha de reversão. Notam-se algumas lacunas de reabsorção, com clastos em lacunas e justapostos. A porção endosteal não contém espaços medulares e há poucos osteócitos.

A superfície cementária mostra-se uniforme, sem lacunas de reabsorção e revestida por cementoblastos justapostos em paliçada e ao acaso.

O ligamento periodontal mostra-se levemente estreitado na porção mais próxima à crista óssea alveolar e bastante celularizado, com fibroblastos fusiformes e ovalados, alguns em picnose. Os fibroblastos dispõem-se ora fasciculados, ora ao acaso e as fibras colágenas distribuem-se desorganizadamente. Há poucas e discretas áreas hialinas. Os vasos sangüíneos ocorrem em pequeno número e estão principalmente colabados, com discreta hiperemia e não há infiltrado inflamatório.

2 - Área de pressão inter-radicular na raiz distovestibular na região cervical

A superfície óssea periodontal apresenta-se irregular, com linha de reversão e sem lacunas de reabsorção. Encontra-se revestida por osteoblastos justapostos e ao acaso em quase toda a sua extensão. Na superfície endosteal há discretas lacunas de reabsorção, com clastos justapostos e a distância, denotando reabsorção a distância. Os espaços medulares são amplos e ricamente vascularizados.

A superfície cementária mostra-se regular e uniforme e parcialmente revestida por cementoblastos justapostos e ao acaso, com ausência destas células quando há áreas hialinas. Não são notadas reabsorções cementárias. 
O ligamento periodontal mostra-se com espessura irregular e levemente estreitado. Há poucos fibroblastos, tipicamente fusiformes, além de pequenos e picnóticos. As fibras colágenas distribuem-se em feixes desorganizados. Há áreas hialinas, algumas estendendo-se por toda a espessura do ligamento periodontal. Os vasos sangüíneos mostram-se colabados, dilatados e hiperêmicos. Nota-se discreto infiltrado inflamatório mononuclear justaposto às áreas hialinas.

3 - Área de tensão externa na raiz distovestibular na região cervical

A superfície óssea periodontal mostra-se recortada e com discretas lacunas de reabsorção, com clastos nas lacunas e justapostos. Notam-se osteoblastos justapostos à superfície e ao acaso, não ocorrendo linha de reversão. Na superfície endosteal há espaços medulares amplos.

A superfície cementária mostra-se uniforme, regular e sem reabsorção, estando revestida por cementoblastos justapostos, em paliçada e ao acaso.

O ligamento periodontal mostra-se levemente espessado, com fibroblastos fusiformes e ovalados, ora fasciculados, ora ao acaso, com fibras colágenas perpendiculares às superfícies óssea e cementária e distendidas. Há discretas áreas hialinas e os vasos sangüíneos estão dilatados e hiperêmicos, além de ocorrer discreto edema. Nota-se discreto infiltrado inflamatório mononuclear.

4 - Área de tensão inter-radicular na raiz mesiovestibular na região cervical

A superfície óssea periodontal mostra-se irregular, com discreta reabsorção e clastos dispostos a distância. Apresenta-se revestida por osteoblastos justapostos, em paliçada e ao acaso e com discreta linha de reversão. A superfície endosteal mostra-se com amplos espaços medulares e linhas de reversão intensas. 
A superfície cementária apresenta-se regular, revestida por cementoblastos justapostos, em paliçada e ao acaso. Não ocorrem lacunas de reabsorção.

No ligamento periodontal nota-se espessura normal e constante, muita celularidade com fibroblastos fusiformes e ovalados, sendo alguns picnóticos. As fibras colágenas mostram-se perpendiculares e organizadas e ocorrem discretas áreas hialinas. Os vasos sangüíneos estão colabados, dilatados e hiperêmicos e não há infiltrado inflamatório.

As figuras 20, 21, 22 e 23 representam fotomicrografias ilustrativas de fenômenos observados nas áreas correspondentes à pressão e tensão nos animais do Grupo OV 1. 


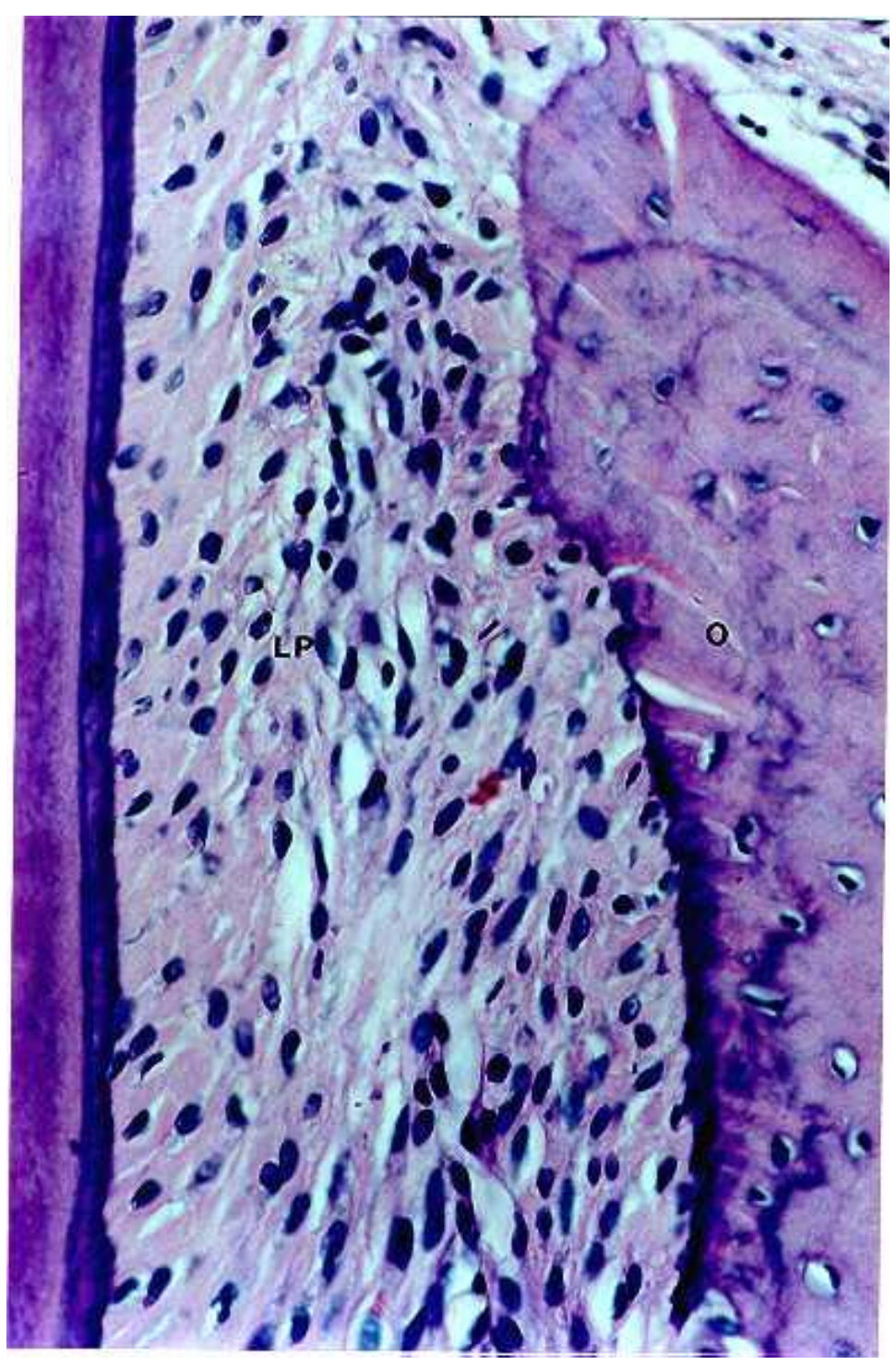

FIGURA 20 - Região cervical do lado mesial da raiz mesiovestibular, referente à área de pressão externa nos animais do Grupo oV 1. Notase ligamento periodontal com fibroblastos fusiformes, ovalados e ao acaso, com poucos vasos sangüíneos e discretas áreas hialinas; superfície óssea periodontal uniforme, revestida por osteoblastos e sem lacunas de reabsorção e com crista alveolar arredondada; superfície cementária uniforme e revestida por cementoblastos e sem lacunas de reabsorção. (Coloração HE; objetiva: 40x). C = cemento; $\mathrm{O}=$ osso; LP = ligamento periodontal. 


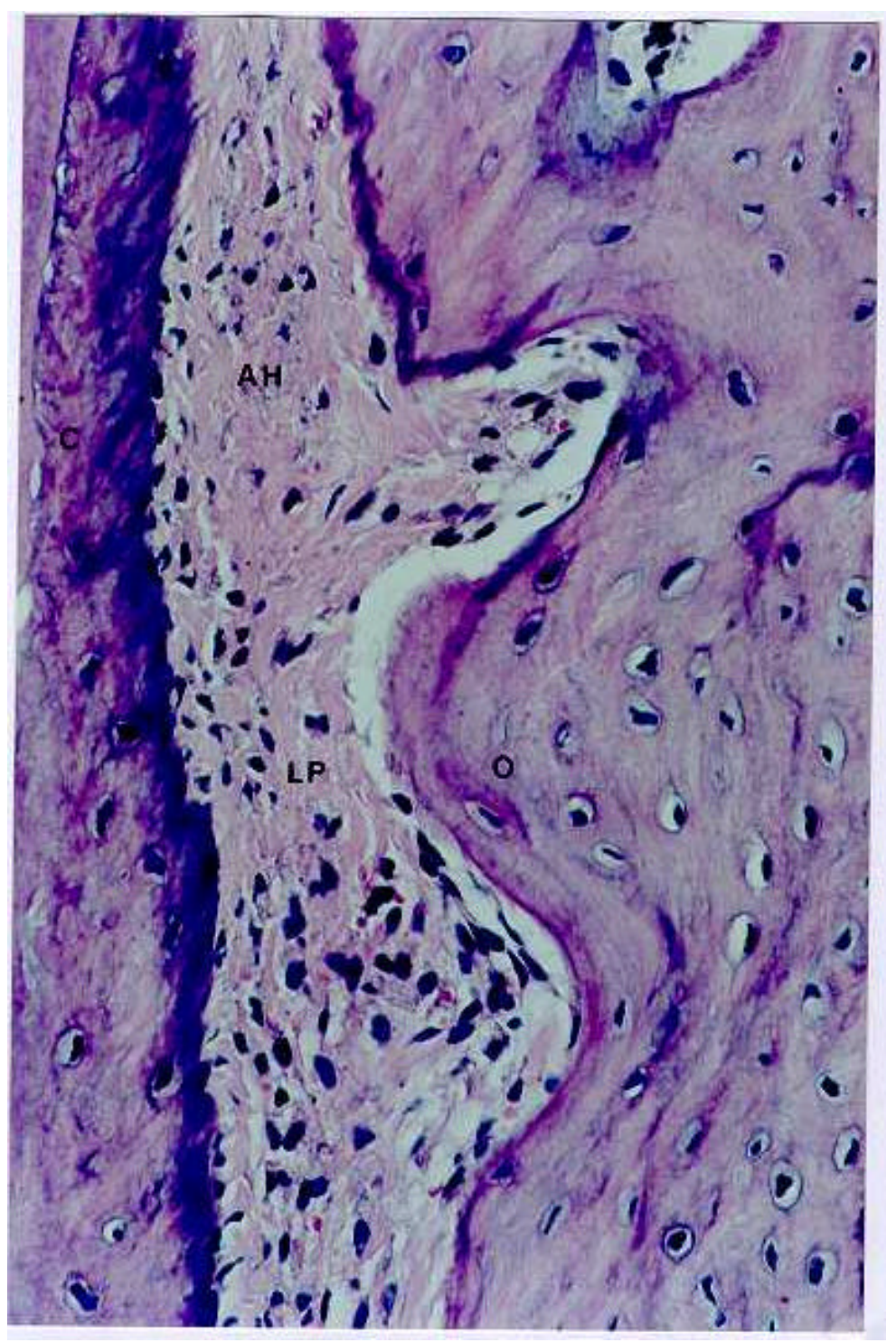

FIGURA 21 - Região cervical do lado mesial da raiz distovestibular, referente à área de pressão inter-radicular nos animais do Grupo oV 1. Nota-se ligamento periodontal pobremente celularizado, com fibroblastos amorfos e em picnose, pouco vascularizado e com proeminentes áreas hialinas.; superfície óssea periodontal irregular, com poucos osteoblastos, sem lacunas de reabsorção; superfície cementária levemente irregular e revestida parcialmente por cementoblastos com núcleo picnótico e sem lacunas de reabsorção. (Coloração HE; objetiva: 40x). $\mathrm{C}=$ cemento; $\mathrm{O}=$ osso; $\mathrm{LP}$ = ligamento periodontal; $\mathrm{AH}$ = área hialina. 


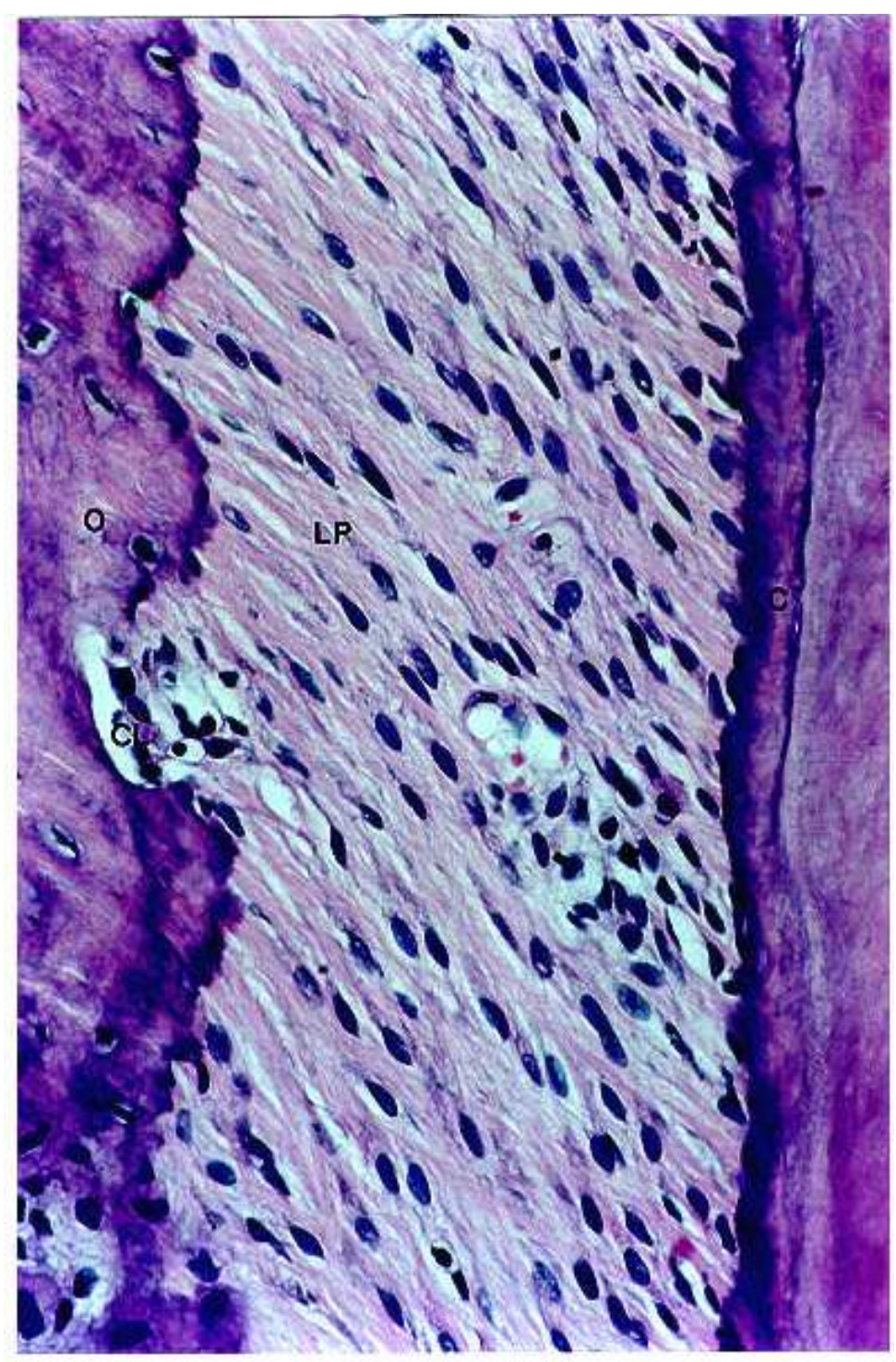

Figura 22 - Região cervical do lado distal da raiz mesiovestibular, referente à área de tensão inter-radicular nos animais do Grupo oV 1. Nota-se ligamento periodontal com muitos fibroblastos fusiformes, ovalados e fasciculados, com discreta vascularização e algumas áreas hialinas; superfície óssea periodontal irregular, revestida por parcialmente por osteoblastos, e com uma lacuna de reabsorção; superfície cementária uniforme, revestida por cementoblastos e sem lacunas de reabsorção. (Coloração HE; objetiva: 40x). C = cemento; $\mathrm{O}=$ osso; LP = ligamento periodontal; CL $=$ clasto . 


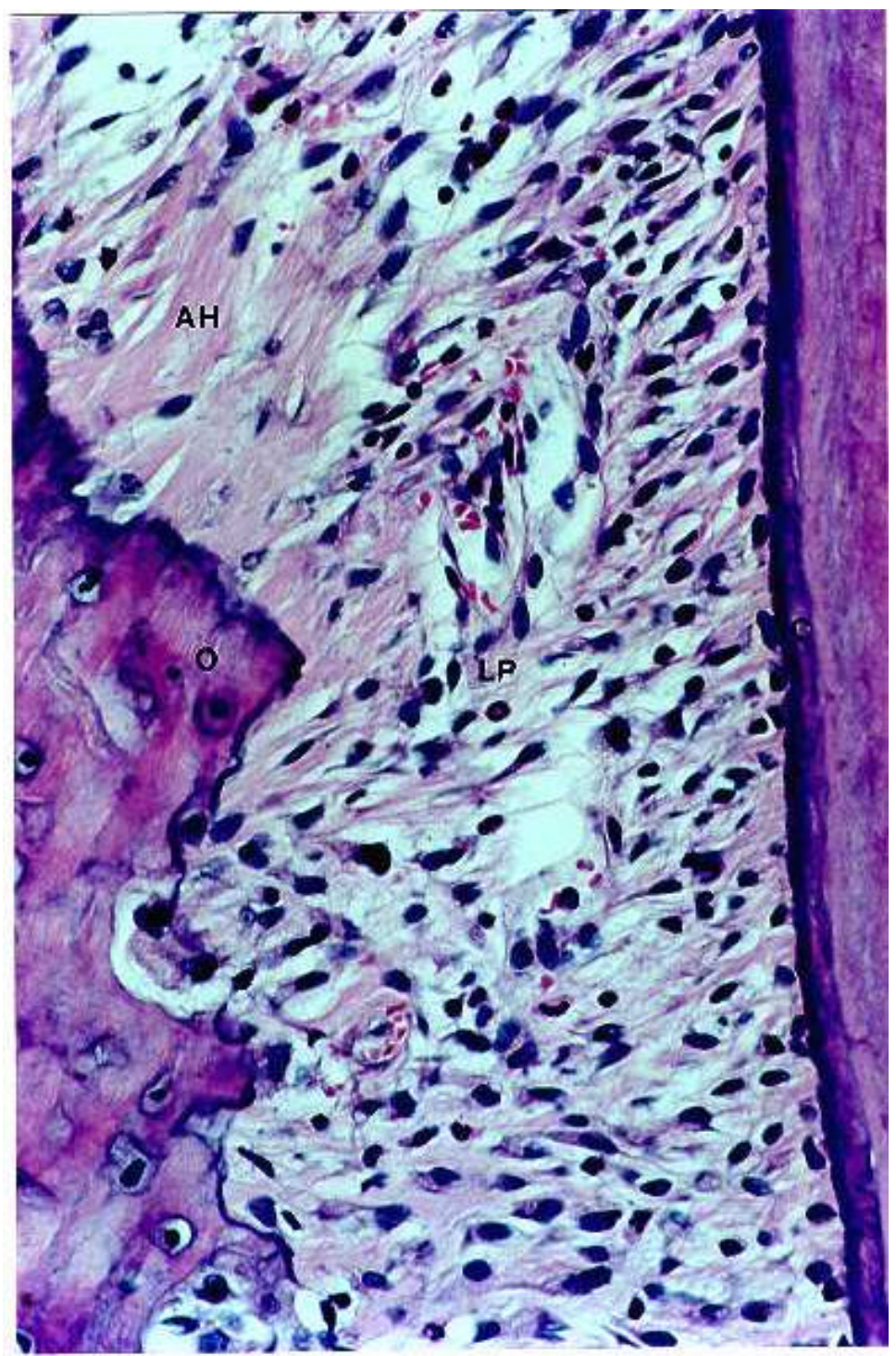

Figura 23 - Região cervical do lado distal da raiz distovestibular, referente à área de tensão externa nos animais do Grupo oV 1. Nota-se ligamento periodontal com espessura aumentada, com fibroblastos fusiformes, ovalados, alguns picnóticos e ao acaso, com áreas hialinas e com poucos vasos sangüíneos ora dilatados e hiperêmicos; superfície óssea periodontal bastante recortada, revestida parcialmente por osteoblastos, com lacuna de reabsorção e clasto em seu interior; superfície cementária uniforme e revestida por cementoblastos e sem lacunas de reabsorção. (Coloração HE; objetiva: 40x). $\mathrm{C}=$ cemento; $\mathrm{O}=$ osso; $\mathrm{LP}=$ ligamento periodontal; $\mathrm{AH}$ = área hialina. 


\section{GRUPO OV 3}

O grupo OV 3 corresponde aos animais com 93 dias de idade, com movimentação dentária por três dias após 50 dias de ovariectomia induzida.

1 - Área de pressão externa na raiz mesiovestibular na região cervical

A crista óssea alveolar mostra-se irregular, com discreta lacuna de reabsorção sem clasto. A superfície periodontal mostra-se uniforme, levemente irregular e com osteóide. Nota-se revestimento parcial por osteoblastos justapostos ao acaso e em paliçada e há poucas lacunas de reabsorção, com clastos a distância. Na superfície endosteal há poucos espaços medulares e muitos osteócitos.

A superfície cementária mostra-se regular e revestida por cementoblastos justapostos ao acaso e em paliçada.

O ligamento periodontal apresenta espessura constante e normal, e rica celularidade, com fibroblastos ora fusiformes, ora ovalados, e muitos com núcleo picnótico. Há fibras colágenas dispostas em feixes organizados e perpendiculares às superfícies óssea e cementária. As áreas hialinas são poucas e pequenas e os vasos sangüíneos mostram-se colabados e dilatados, com pouca evidência de hiperemia e não há infiltrado inflamatório.

2 - Área de pressão inter-radicular na raiz distovestibular na região cervical

A superfície óssea periodontal mostra-se uniforme e parcialmente revestida por osteoblastos justapostos e ao acaso. Nota-se discreta linha de reversão e não há lacunas de reabsorção. Na superfície endosteal há poucos espaços medulares e ocorrem lacunas de reabsorção, sugerindo reabsorção a distância, com clastos em lacunas e justapostos.

A superfície cementária mostra-se com contorno levemente irregular e parcialmente revestida por cementoblastos justapostos e dispostos ao acaso. Não ocorrem reabsorções cementárias.

No ligamento periodontal ocorre estreitamento, principalmente na porção mais cervical. A celularidade está diminuída, notando-se fibroblastos 
ovalados, com núcleo picnótico e ao acaso. Ocorrem fibras colágenas em pequena quantidade e desorganizadas. As áreas hialinas são pequenas e discretas. Notam-se vasos sangüíneos dilatados ora hiperêmicos, ora não e há discreto infiltrado inflamatório mononuclear.

3 - Área de tensão externa na raiz distovestibular na região cervical

A superfície óssea periodontal mostra-se irregular, com várias lacunas de reabsorção, com clastos dispostos nas lacunas e justapostos. A superfície está parcialmente revestida por osteoblastos justapostos e ao acaso. Não são observadas linhas de reversão. Na superfície endosteal há poucos espaços medulares.

A superfície cementária mostra-se uniforme e regular, sem reabsorção e revestida por cementoblastos justapostos, ao acaso e em paliçada.

O ligamento periodontal mostra espessura aumentada e bastante celularidade, com fibroblastos fusiformes e ovalados, e alguns com núcleo picnótico; os feixes de fibras colágenas encontram-se perpendiculares e desorganizados. Notam-se muitos vasos sangüíneos, dilatados e hiperêmicos, e discretas áreas de edema. Há moderado infiltrado inflamatório, predominantemente mononuclear, notando-se neutrófilos na região de crista óssea alveolar.

4 - Área de tensão inter-radicular na raiz mesiovestibular na região cervical

A superfície óssea periodontal mostra-se uniforme e regular, revestida parcialmente por osteoblastos justapostos, ao acaso e em paliçada; ocorrendo discreta linha de reversão Não há lacunas de reabsorção ativa, notando-se alguns clastos localizados a distância da superfície óssea. $\mathrm{Na}$ superfície endosteal há espaços medulares amplos e lacunas de reabsorção.

A superfície cementária mostra-se uniforme, regular e revestida por cementoblastos justapostos em paliçada e ao acaso e não ocorrem lacunas de reabsorção.

O ligamento periodontal mostra-se mais espesso e bastante celularizado, com fibroblastos fusiformes e ovalados, fasciculados e às vezes com 
núcleo picnótico. As fibras colágenas estão organizadas em feixes perpendiculares e distendidos. Não são notadas áreas hialinas. Os vasos sangüíneos estão dilatados e hiperêmicos e há discreto infiltrado inflamatório mononuclear.

As figuras 24, 25, 26 e 27 representam fotomicrografias ilustrativas de fenômenos observados nas áreas correspondentes à pressão e tensão nos animais do Grupo OV 3. 


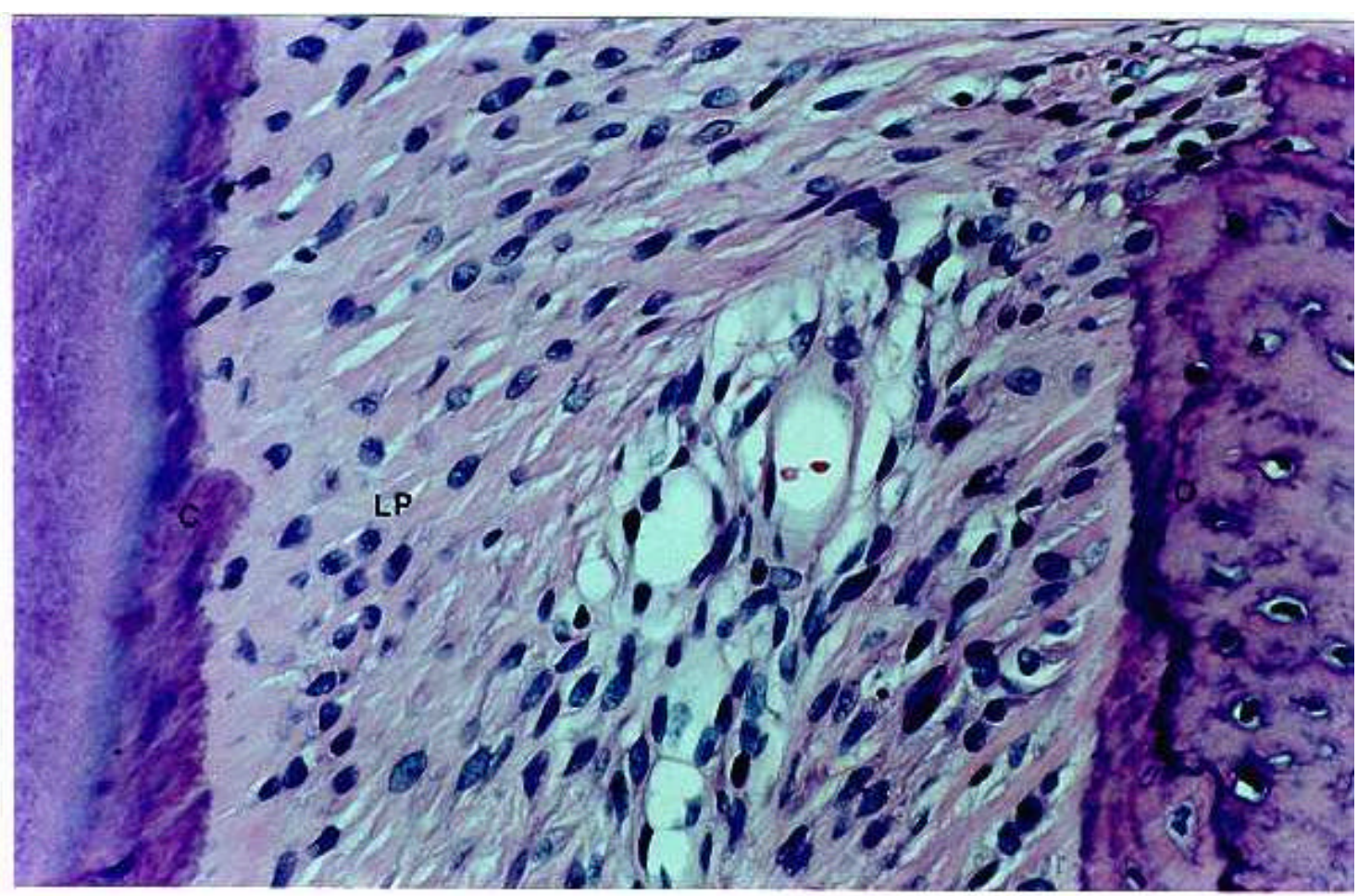

FIGURA 24 - Região cervical do lado mesial da raiz mesiovestibular, referente à área de pressão externa nos animais do Grupo oV 3 Notase ligamento periodontal com fibroblastos fusiformes, ovalados, ora fasciculados, ora ao acaso, com vasos sangüíneos dilatados; superfície óssea periodontal uniforme, revestida por osteoblastos, com linhas de reversão, sem lacunas de reabsorção e com crista alveolar levemente afilada; superfície cementária uniforme e revestida parcialmente por cementoblastos e sem lacunas de reabsorção. (Coloração HE; objetiva: 40x). C = cemento; $\mathrm{O}=$ osso; $\mathrm{LP}=$ ligamento periodontal. 


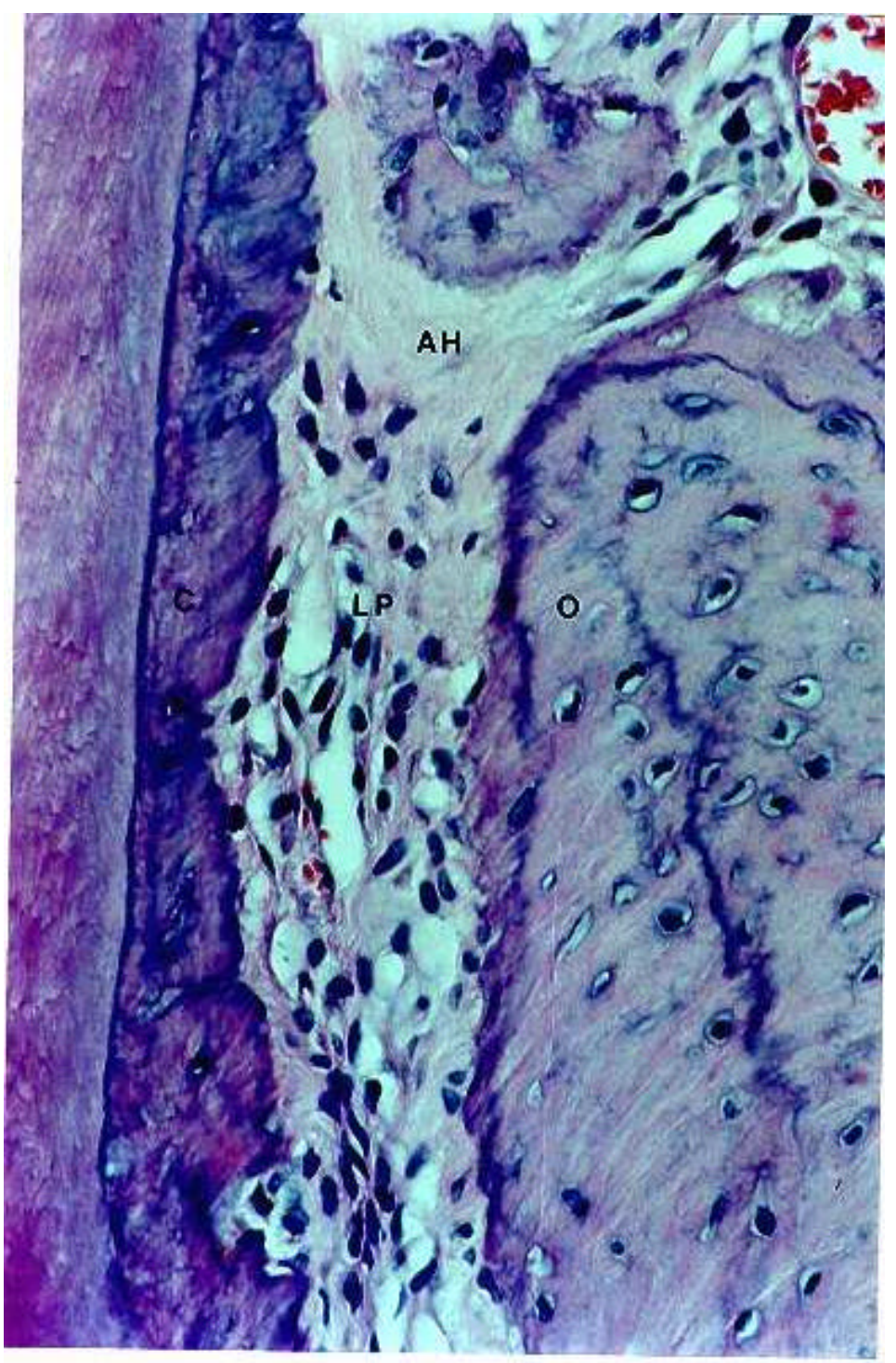

FIGURA 25 - Região cervical do lado mesial da raiz distovestibular, referente à área de pressão inter-radicular nos animais do Grupo OV 3. Notase ligamento periodontal pobremente celularizado, com fibroblastos amorfos e picnóticos, com alguns vasos sangüíneos dilatados e com área hialina; superfície óssea periodontal uniforme, com poucos osteoblastos, sem lacunas de reabsorção; superfície cementária levemente irregular e revestida parcialmente por cementoblastos com núcleo picnótico e sem lacunas de reabsorção. (Coloração HE; objetiva: 40x). C = cemento; O = osso; LP = ligamento periodontal; $\mathrm{AH}$ = área hialina. 


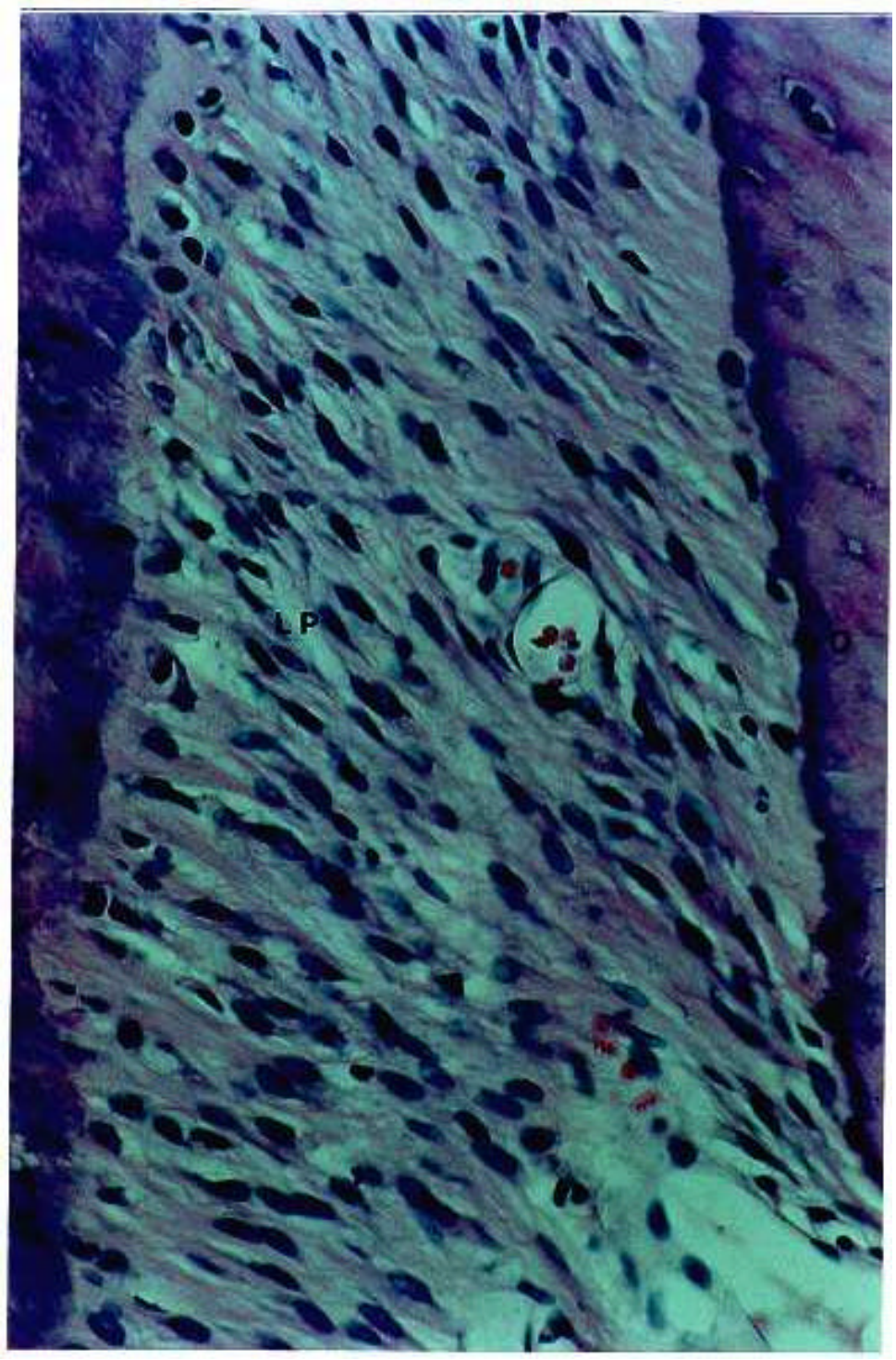

Figura 26 - Região cervical do lado distal da raiz mesiovestibular, referente à área de tensão inter-radicular nos animais do Grupo oV 3. Nota-se ligamento periodontal com muitos fibroblastos fusiformes, ovalados e fasciculados e com discreta vascularização; superfície óssea periodontal uniforme, revestida por osteoblastos, e sem lacunas de reabsorção; superfície cementária uniforme, revestida por cementoblastos e sem lacunas de reabsorção. (Coloração HE; objetiva: 40x). C = cemento; $\mathrm{O}=$ osso; LP = ligamento periodontal. 


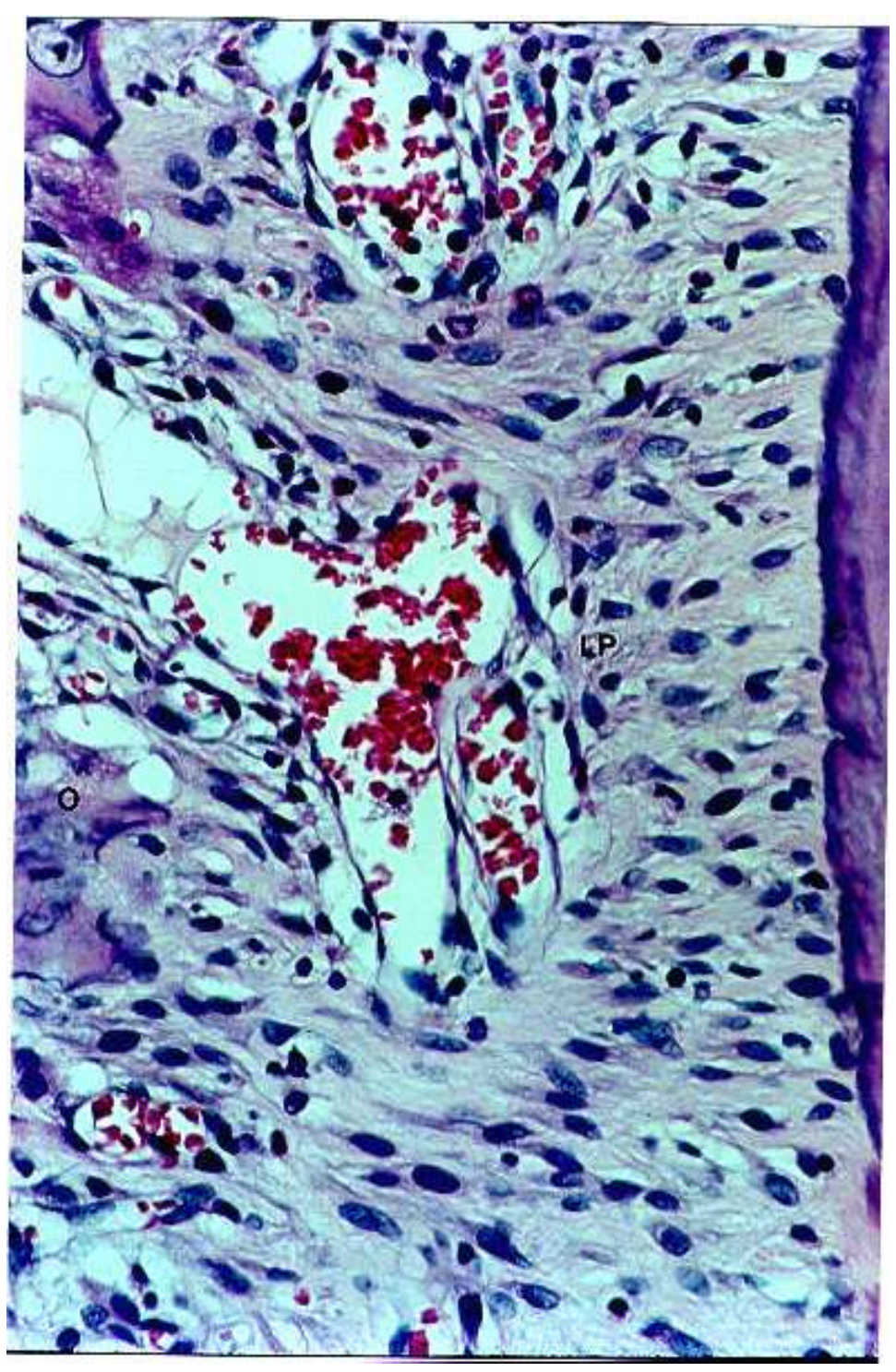

Figura 27 - Região cervical do lado distal da raiz distovestibular, referente à área de tensão externa nos animais do Grupo oV 3 Nota-se ligamento periodontal com espessura aumentada, com fibroblastos fusiformes, ovalados, alguns picnóticos e ao acaso, e com vasos sangüíneos dilatados e hiperêmicos; superfície óssea periodontal bastante recortada, revestida parcialmente por osteoblastos, superfície cementária uniforme e revestida por cementoblastos e sem acunas de reabsorção. (Coloração HE; objetiva: 40x). $C$ = cemento; $\mathrm{O}=$ osso; $\mathrm{LP}=$ ligamento periodontal. 


\section{GRUPO OV 5}

O grupo OV 5 corresponde aos animais com 95 dias de idade, com movimentação dentária por cinco dias após 50 dias de ovariectomia induzida.

1 - Área de pressão externa na raiz mesiovestibular na região cervical

O tecido ósseo apresenta crista óssea alveolar e superfície periodontal bastante irregulares. A superfície óssea periodontal possui pouco osteóide e está revestida parcialmente por osteoblastos justapostos ao acaso e em paliçada. Não ocorrem lacunas de reabsorção. Na superfície endosteal há poucos espaços medulares e muitos osteócitos.

$O$ cemento mostra superfície uniforme e revestida por cementoblastos justapostos e dispostos ao acaso e em paliçada e sem lacunas de reabsorção.

No ligamento periodontal há rica celularidade, com fibroblastos ora fusiformes, ora ovalados, e muitos em picnose; notando-se distribuição ora ao acaso, ora fasciculados. A espessura do ligamento periodontal é normal e regular. As fibras colágenas dispõem-se em feixes perpendiculares e/ou desorganizados e há poucas e pequenas áreas hialinas. Notam-se poucos vasos sangüíneos, que estão colabados e dilatados, com discreta hiperemia e não há infiltrado inflamatório.

2 - Área de pressão inter-radicular na raiz distovestibular na região cervical

A superfície óssea periodontal apresenta-se levemente irregular e revestida parcialmente por osteoblastos justapostos e a distância e dispostos ao acaso. Nota-se discreta linha de reversão e não há reabsorção. Na superfície endosteal os espaços medulares apresentam-se com muitas lacunas de reabsorção, ocorrendo a reabsorção a distância. Os clastos são observados em lacunas de reabsorção e justapostos à superfície óssea.

A superfície cementária mostra-se com contorno levemente irregular e revestida por cementoblastos justapostos e a distância e dispostos ao acaso; 
sendo que alguns possuem núcleo picnótico. Não ocorrem reabsorções cementárias.

O ligamento periodontal mostra-se com espessura diminuída, principalmente na porção mais cervical, onde ocorrem áreas hialinas intensas, às vezes com início de anquilose; notam-se outras áreas hialinas discretas e pequenas. A celularidade está diminuída, com fibroblastos ovalados e com núcleo picnótico. Notam-se vasos sangüíneos dilatados ora hiperêmicos, ora não e há moderado infiltrado inflamatório mononuclear justapostos às áreas hialinas.

3 - Área de tensão externa na raiz distovestibular na região cervical

O tecido ósseo apresenta superfície periodontal irregular, com lacunas de reabsorção e clastos em lacunas e justapostos. Há revestimento parcial por osteoblastos justapostos e ao acaso e são observadas discretas linhas de reversão. Na superfície endosteal há poucos espaços medulares.

A superfície cementária mostra-se regular, sem lacunas de reabsorção, e revestida por cementoblastos justapostos ao acaso e em paliçada.

No ligamento periodontal, a espessura está levemente aumentada e há bastante celularidade, com fibroblastos fusiformes e ovalados distribuídos em fascículos; alguns fibroblastos mostram-se com núcleo picnótico. Notam-se fibras colágenas em feixes ora perpendiculares, ora ao acaso, e há discretas áreas hialinas. Os vasos sangüíneos ocorrem em grande quantidade e estão dilatados e hiperêmicos, notando-se também pequenas áreas de edema. Há moderado infiltrado inflamatório, predominantemente mononuclear e principalmente na região mais cervical.

4 - Área de tensão inter-radicular na raiz mesiovestibular na região cervical

A superfície óssea periodontal mostra-se uniforme, regular e revestida parcialmente por osteoblastos justapostos e ao acaso e em paliçada. Não há lacunas ativas de reabsorção, notando-se alguns clastos localizados a distância e há discreta linha de reversão. Na superfície endosteal há espaços medulares amplos e lacunas de reabsorção. 
A superfície cementária mostra-se uniforme, regular e sem lacunas de reabsorção, com cementoblastos justapostos à superfície, em paliçada e ao acaso.

O ligamento periodontal mostra-se aumentado e bastante celularizado, com fibroblastos fusiformes e ovalados, sendo alguns picnóticos. As fibras colágenas organizam-se em feixes perpendiculares e às vezes distendidos. Não ocorrem áreas hialinas. Os vasos sangüíneos estão dilatados e hiperêmicos e há discreto infiltrado inflamatório mononuclear.

As figuras 28, 29, 30 e 31 representam fotomicrografias ilustrativas de fenômenos observados nas áreas correspondentes à pressão e tensão nos animais do Grupo OV 5. 


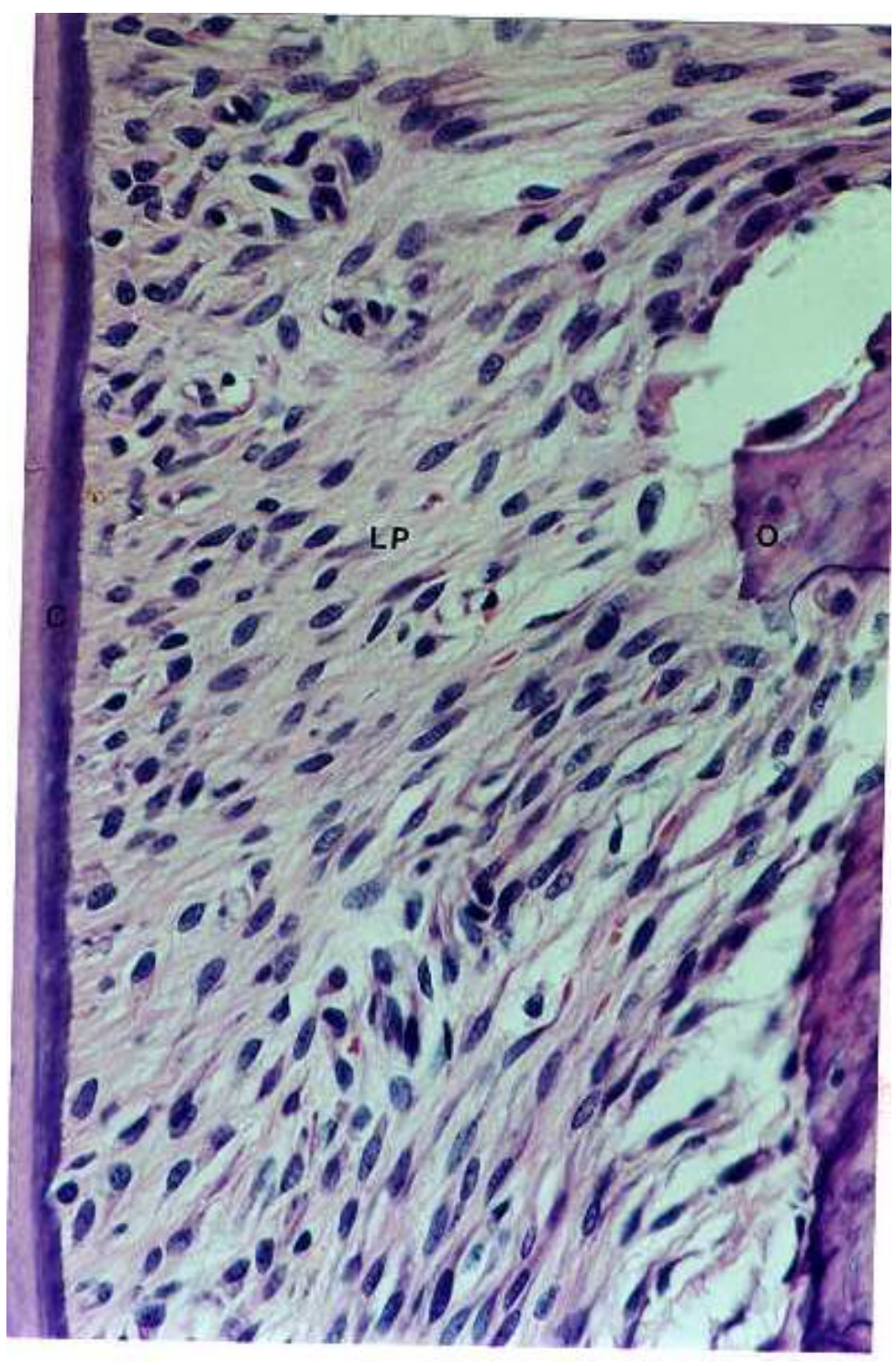

FIGURA 28 - Região cervical do lado mesial da raiz mesiovestibular, referente à área de pressão externa nos animais do Grupo OV 5. Nota-se ligamento periodontal ricamente celularizado, com fibroblastos fusiformes, ovalados e fasciculados e com discreta vascularização; superfície óssea periodontal parcialmente recortada, revestida parcialmente por osteoblastos; superfície cementária uniforme e revestida por cementoblastos e sem lacunas de reabsorção. (Coloração HE; objetiva: 40x). C = cemento; $\mathrm{O}=$ osso; $\mathrm{LP}=$ ligamento periodontal. 


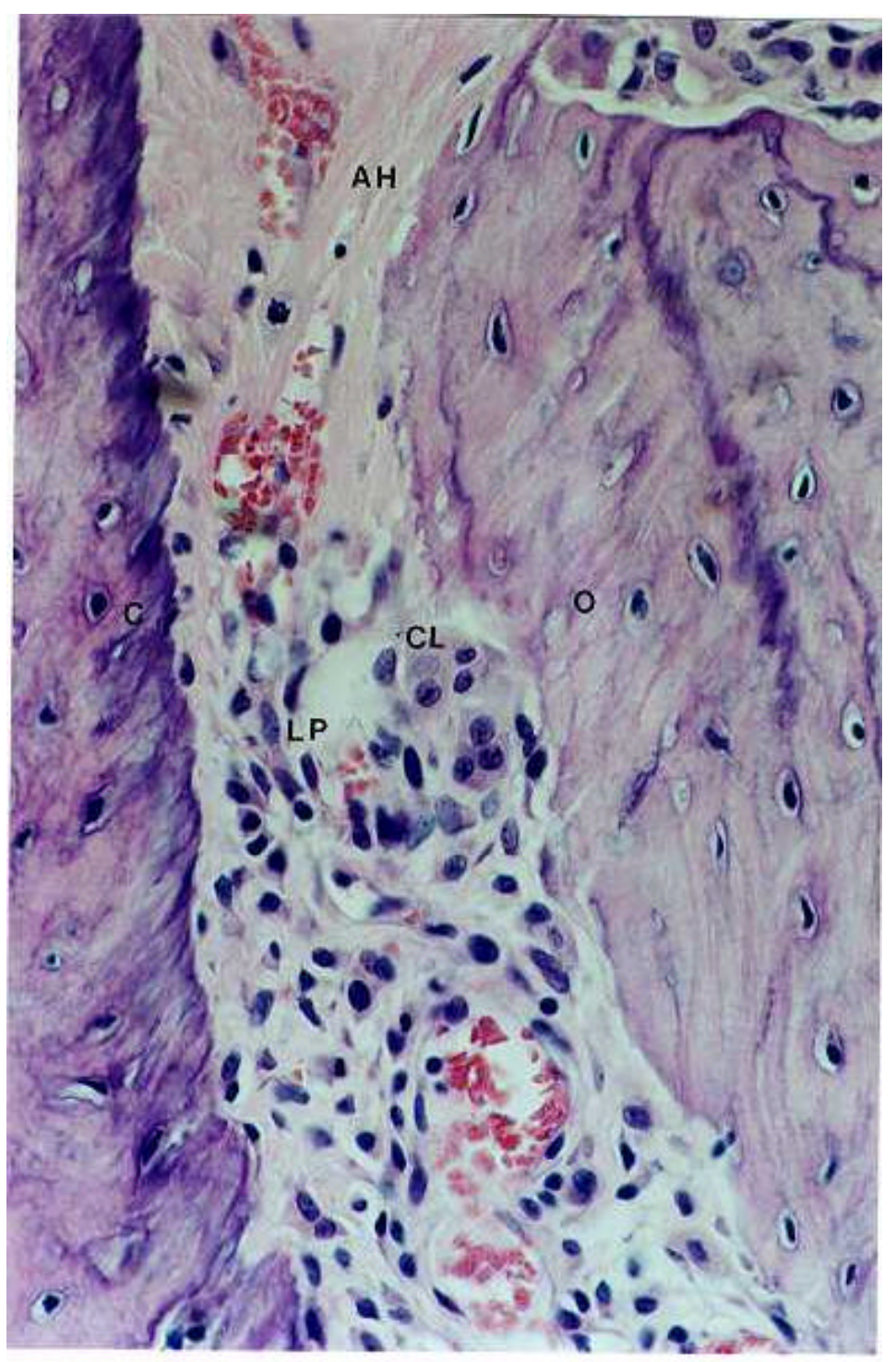

FIGURA 29 - Região cervical do lado mesial da raiz distovestibular, referente à área de pressão inter-radicular nos animais do Grupo OV 5. Notase ligamento periodontal com espessura diminuída, pobremente celularizado, com fibroblastos ovalados e picnóticos, com vasos sangüíneos dilatados e hiperêmicos e com extensa área hialina; superfície óssea periodontal levemente irregular, com poucos osteoblastos, com lacuna de reabsorção e clastos a distância; superfície cementária uniforme e revestida parcialmente por cementoblastos com núcleo picnótico e sem lacunas de reabsorção. (Coloração HE; objetiva: 40x). C = cemento; $\mathrm{O}=$ osso; LP = ligamento periodontal; $\mathrm{AH}$ = área hialina; $\mathrm{CL}=$ clasto. 


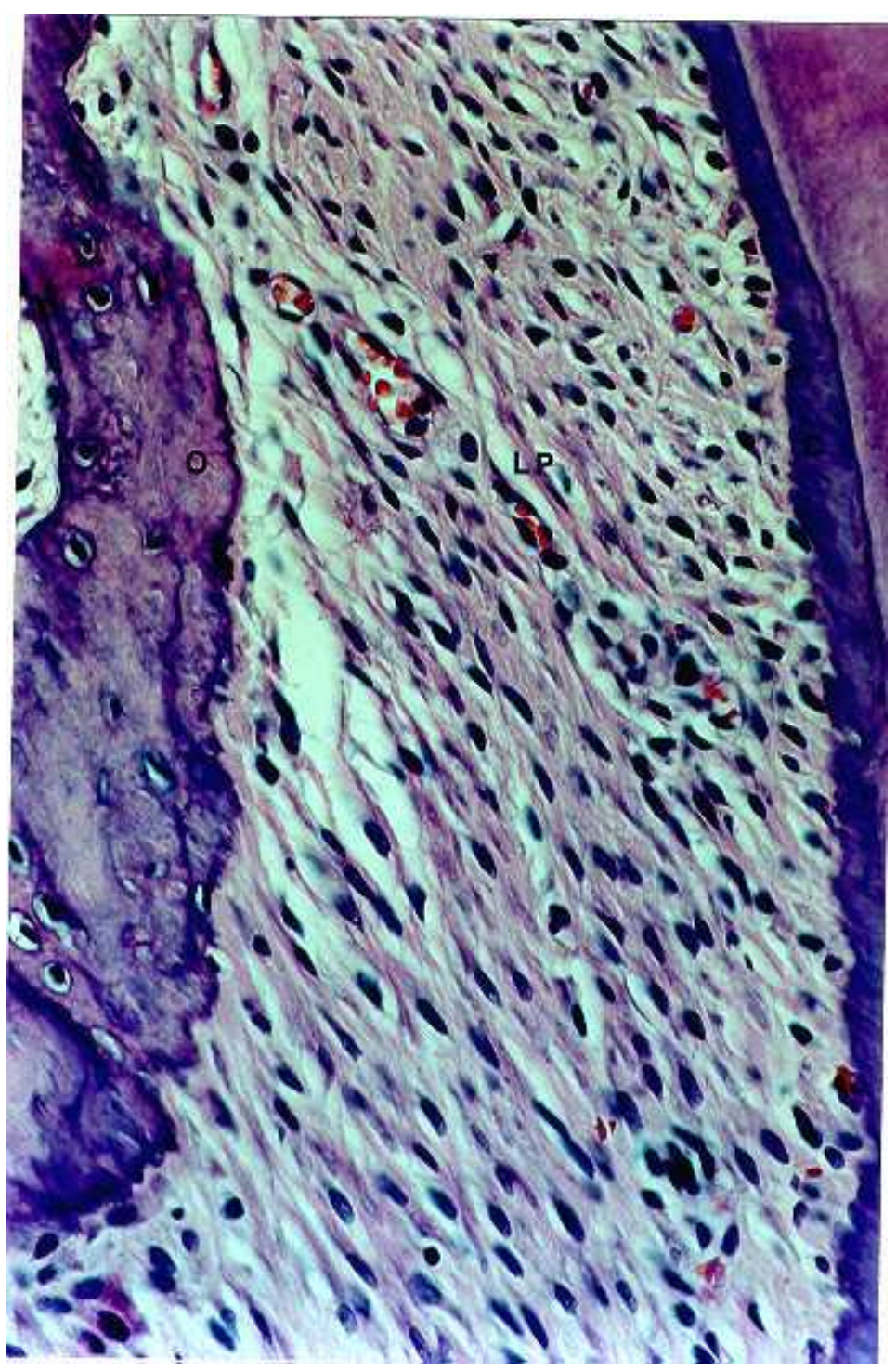

Figura 30 - Região cervical do lado distal da raiz mesiovestibular, referente à área de tensão inter-radicular nos animais do Grupo OV 5. Nota-se ligamento periodontal com muitos fibroblastos fusiformes, ovalados, fasciculados com núcleo picnótico e com discreta vascularização; superfície óssea periodontal uniforme, revestida parcialmente por osteoblastos, com linhas de reversão e sem lacunas de reabsorção; superfície cementária uniforme, revestida por cementoblastos e sem lacunas de reabsorção. (Coloração HE; objetiva: 40x). C = cemento; $\mathrm{O}=$ osso; LP = ligamento periodontal. 


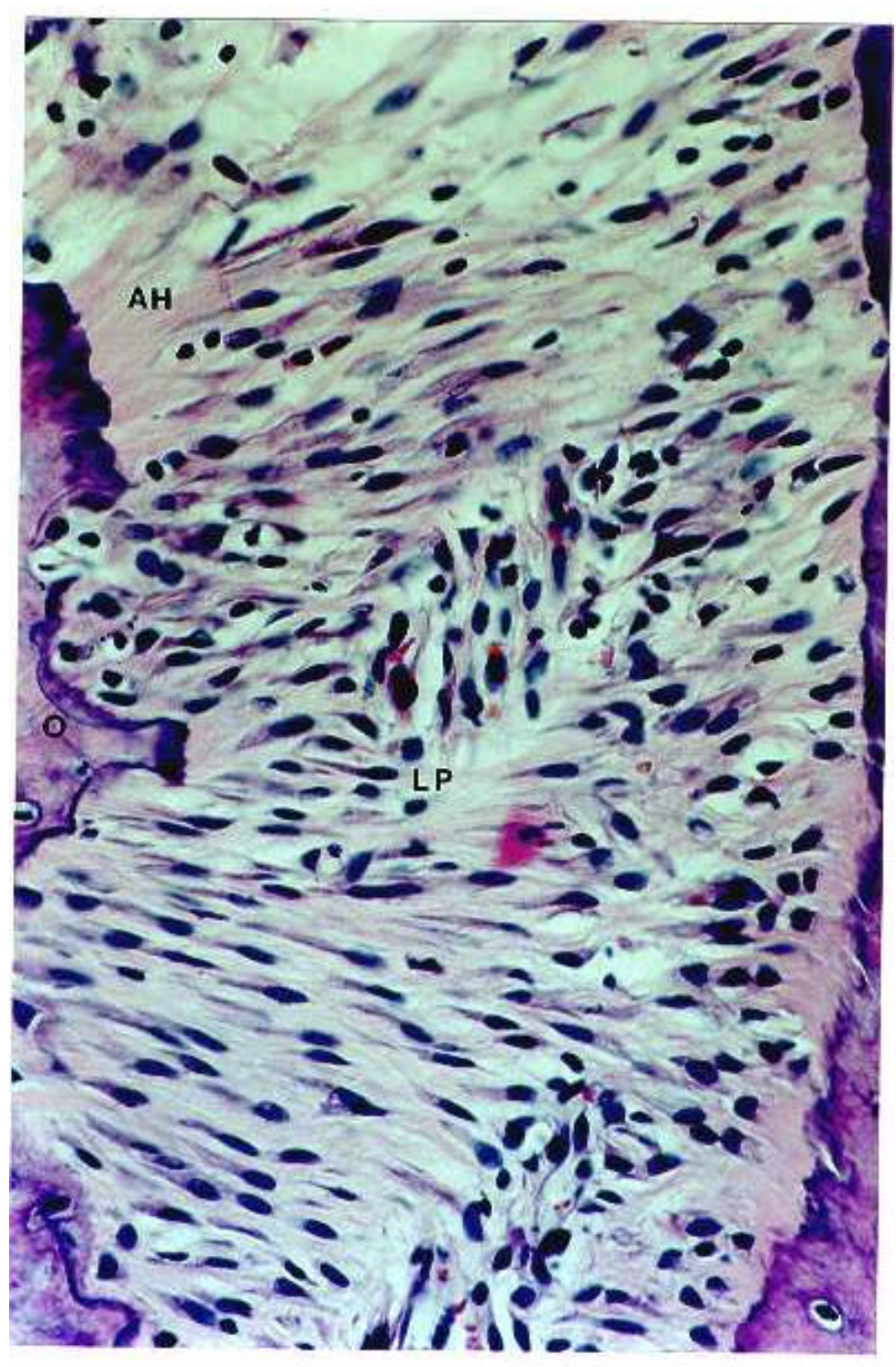

Figura 31 - Região cervical do lado distal da raiz distovestibular, referente à área de tensão externa nos animais do Grupo oV $\mathbf{5}$ Nota-se ligamento periodontal com espessura aumentada, com fibroblastos fusiformes, ovalados, alguns picnóticos, fasciculados e ao acaso, e discreta vascularização, além de área hialina; superfície óssea periodontal bastante recortada, revestida parcialmente por osteoblastos, sem lacunas de reabsorção; superfície cementária uniforme e revestida parcialmente por cementoblastos e sem lacunas de reabsorção. (Coloração HE; objetiva: 40x). $\mathrm{C}=$ cemento; $\mathrm{O}=$ osso; $\mathrm{LP}$ = ligamento periodontal; $\mathrm{AH}$ = área hialina. 


\section{GRUPOS OS}

Os grupos OS 1, OS 3 e OS 5 correspondem aos animais com 91, 93 e 95 dias de idade, com movimentação dentária, respectivamente por 24 horas, três dias e cinco dias após 50 dias de ovariectomia simulada.

Os resultados obtidos nestes grupos experimentais são semelhantes aos obtidos no grupos MD 1, MD 3 e MD 5; portanto a descrição dos resultados dos Grupos OS corresponde às dos Grupos MD.

A seguir serão apresentados os quadros com a distribuição dos achados microscópios referentes aos fenômenos morfologicamente detectados nos animais dos Grupos Experimentais. 


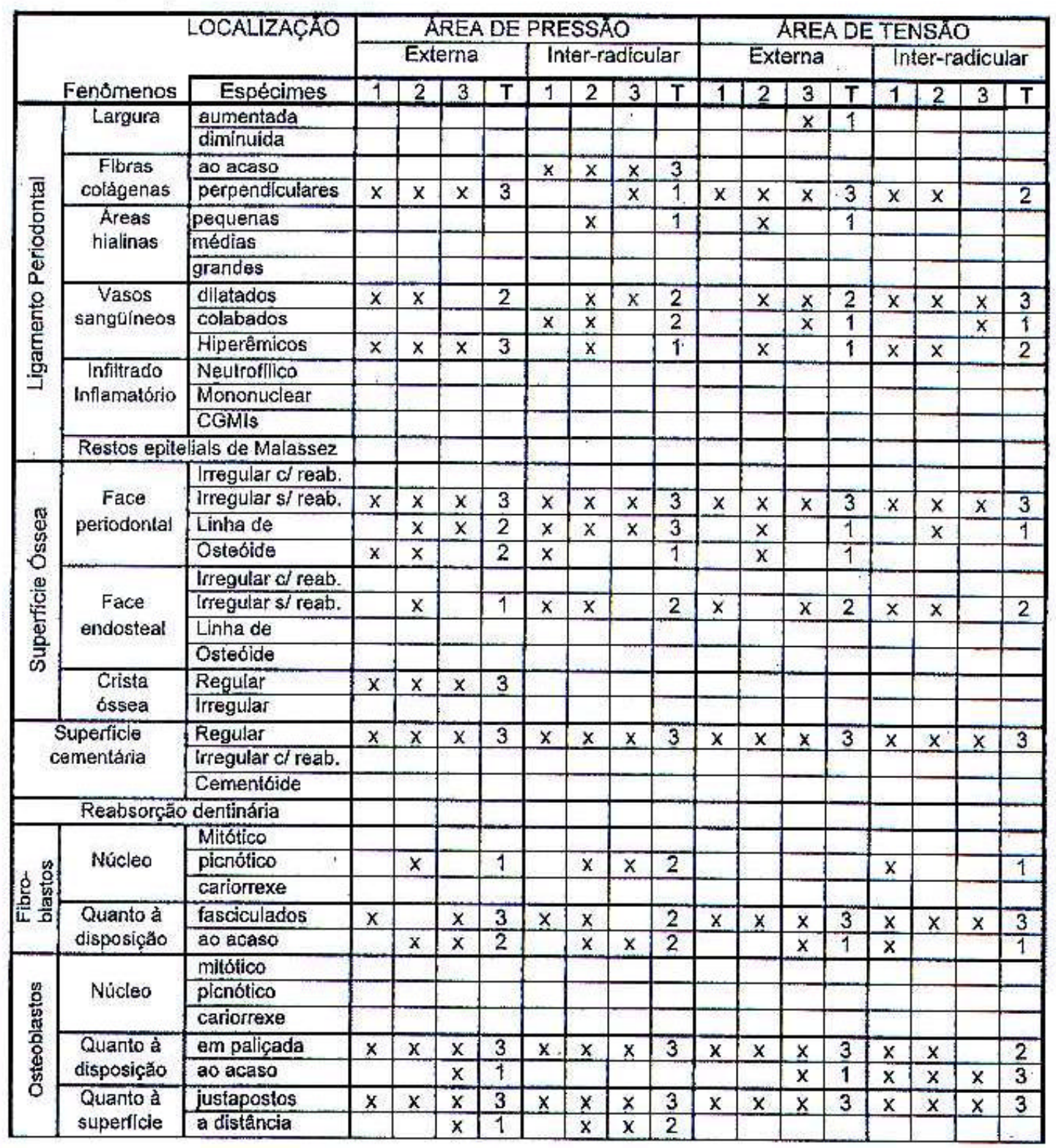




\section{continuaçāo}

\begin{tabular}{|c|c|c|c|c|c|c|c|c|c|c|c|c|c|c|c|c|c|c|}
\hline & & & 1 & 2 & 3 & $I$ & 1 & 2 & 3 & $T$ & 1 & 2 & 3 & $T$ & 1 & 2 & 3 & $T$ \\
\hline \multirow{6}{*}{ 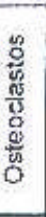 } & \multirow{3}{*}{ Núcleo(s) } & mitótico & & & & & & & & & & & & & & & & \\
\hline & & picnético & & & & & & & & & & & & & & & & \\
\hline & & cariorrexe & & & & & & & & & & & & & & & & \\
\hline & \multirow{3}{*}{$\begin{array}{c}\text { Quanto } \\
\text { à } \\
\text { superficie }\end{array}$} & a distancia & & & & & & & & & & & & & & & & \\
\hline & & justapostos & & & & & & & & & & & & & & & & \\
\hline & & em lacunas & & & & & & & & & & & & & & & & \\
\hline \multirow{7}{*}{ 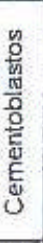 } & \multirow{3}{*}{ Núcleo } & miĺstico & & & & & & & & & & & & & & & & \\
\hline & & picnótico & & & & & & & & & & & & & & & & \\
\hline & & cariorrexe & & & & & & & & & & & & & & & & \\
\hline & \multirow{2}{*}{$\begin{array}{l}\text { Quanto à } \\
\text { disposiçâa }\end{array}$} & em paliçada & $x$ & $\underline{x}$ & $\underline{x}$ & 3 & $x$ & $x$ & $x$ & 3 & $x$ & $x$ & $x$ & 3 & $x$ & $x$ & $x$ & 3 \\
\hline & & ao acaso & & & & & & $x$ & & 1 & + & $x$ & $x$ & 2 & & $x$ & $x$ & 2 \\
\hline & \multirow{2}{*}{$\begin{array}{l}\text { Quanto a } \\
\text { superficie }\end{array}$} & justapostos & $x$ & $x$ & $x$ & 3 & $x$ & $x$ & $x$ & 3 & $\underline{x}$ & $x$ & $x$ & 3 & $x$ & $x$ & $x$ & 3 \\
\hline & & a diståncia & & & & & & & & & & & & & & & & \\
\hline \multirow{6}{*}{ 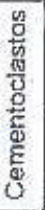 } & \multirow{3}{*}{ Núcleo(s) } & mitólico & & & & & & & & & & & & & & & & \\
\hline & & picnótico & & & & & & & & & & & & & & & & \\
\hline & & cariorrexe & & & & & & & & & & & & & & & & \\
\hline & \multirow{3}{*}{$\begin{array}{c}\text { Quanto } \\
\text { à } \\
\text { superficie }\end{array}$} & a diståncia & & & & & & & & & & & & & & & & \\
\hline & & justapostos & & & & & & & & & & & & & & & & \\
\hline & & nas lacunas & & & & & & & & & & & & & & & & \\
\hline
\end{tabular}

$\mathrm{T}=$ total; $\mathrm{x}=$ presença; $\mathrm{d}=\mathrm{com} ; \mathrm{s} /=\mathrm{sem} ;$ reab, = reabsorção; CGMIs = células gigantes multinucleadas inflamatorias

FIGURA 32 - Distribuição dos achados microscópios referentes aos fenômenos morfologicamente detectados nos animais do Grupo $\mathrm{C}$ 


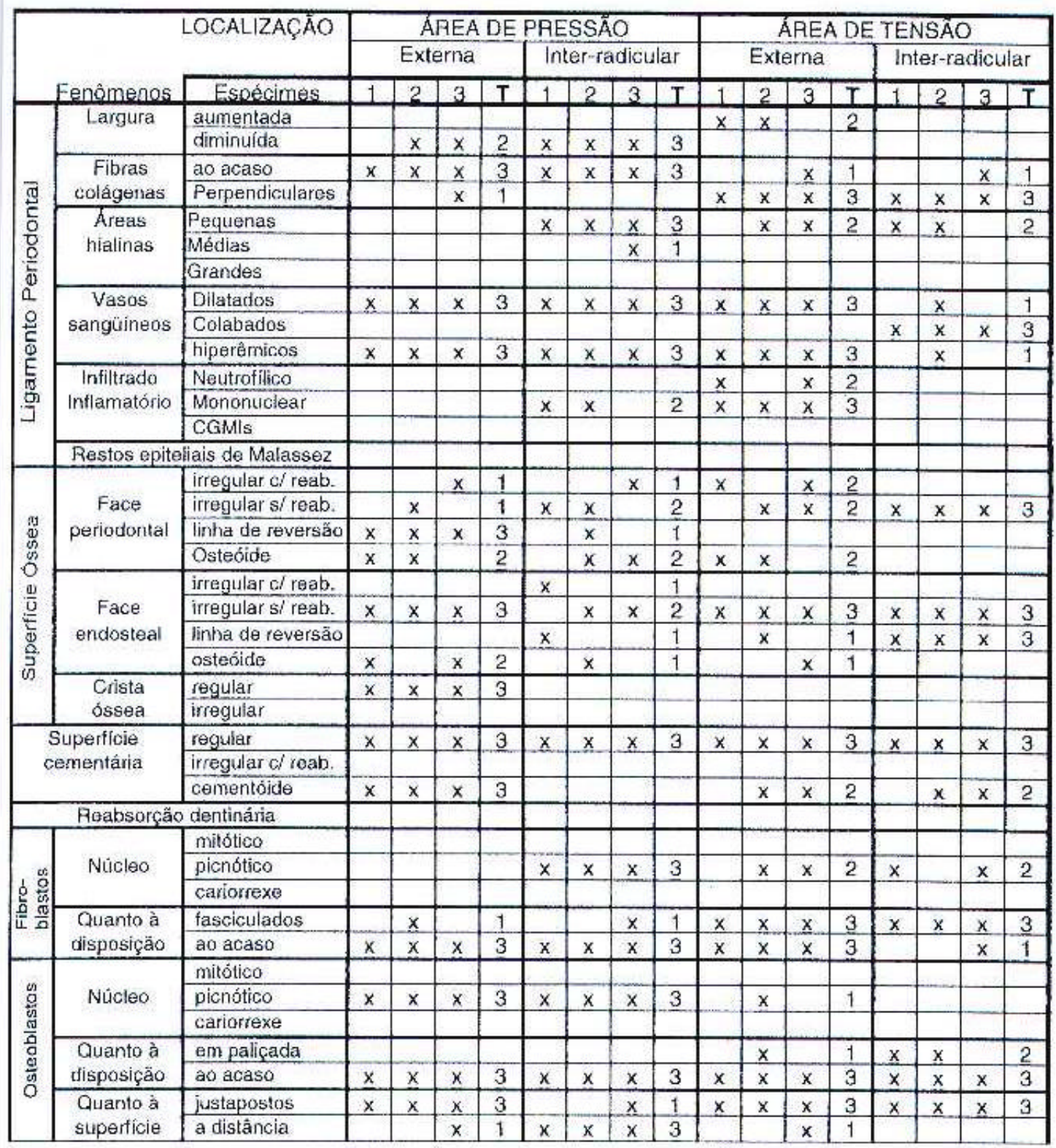


continuação

\begin{tabular}{|c|c|c|c|c|c|c|c|c|c|c|c|c|c|c|c|c|c|c|}
\hline \multirow{7}{*}{ 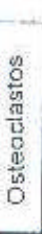 } & & & 1 & 2 & 3 & $T$ & 1 & 2 & 3 & $T$ & 1 & 2 & 3 & $T$ & 1 & 2 & 3 & $T$ \\
\hline & \multirow{3}{*}{ Núcleo(s) } & mitótico & & & & & & & & & & & & & & & & \\
\hline & & picnótico & & & & & & & & & & & & & & & & \\
\hline & & cariorrexe & & & & & & & & & & & & & & & & \\
\hline & \multirow{3}{*}{$\begin{array}{c}\text { Quanto } \\
\text { à } \\
\text { superficie }\end{array}$} & a distância & & $x$ & $x$ & 2 & & & & & & & & & & $x$ & $x$ & 2 \\
\hline & & Justapostos & & & $x$ & 1 & $x$ & $x$ & & 2 & $x$ & $x$ & $x$ & 3 & & & & \\
\hline & & em lacunas & & & & & & $x$ & $x$ & 2 & $x$ & $x$ & & 2 & & & & \\
\hline \multirow{7}{*}{ 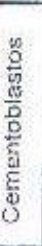 } & \multirow{3}{*}{ Núcleo } & mitólico & & & & & & & & & & & & & & & & \\
\hline & & pienótico & $x$ & & $x$ & 2 & $x$ & & $x$ & 2 & & & & & & & & \\
\hline & & cariorrexe & & & & & & & & & & & & & & & & \\
\hline & \multirow{2}{*}{$\begin{array}{c}\text { Quanto à } \\
\text { disposiçáa }\end{array}$} & em paliçada & $x$ & $x$ & & 2 & $x$ & $x$ & $x$ & 3 & $x$ & $x$ & $x$ & 3 & $x$ & $x$ & $x$ & 3 \\
\hline & & an acaso & & $x$ & $x$ & 2 & $x$ & & & 1 & & $x$ & & 1 & & & & \\
\hline & \multirow{2}{*}{$\begin{array}{l}\text { Quanto à } \\
\text { superficie }\end{array}$} & justapostos & $x$ & $x$ & $x$ & 3 & $x$ & & & 1 & $x$ & $x$ & $x$ & 3 & $x$ & $x$ & $x$ & 3 \\
\hline & & a distância & & & & & & $x$ & $x$ & 2 & & & & & & & & \\
\hline \multirow{6}{*}{ 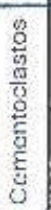 } & \multirow{3}{*}{ Núcleo(s) } & mitóticos & & & & & & & & & & & & & & & & \\
\hline & & pienótico & & & & & & ; & & & & & & & & & & \\
\hline & & cariorrexe & & & & & & & & & & & & & & & & \\
\hline & \multirow{3}{*}{$\begin{array}{c}\text { Quanto } \\
\text { à } \\
\text { superticie }\end{array}$} & a distância & & & & & & & & & & & & & & & & \\
\hline & & justapostos & & & & & & & & & & & & & & & & \\
\hline & & nas lacunas & & & & & & & & & & & & & & & & \\
\hline
\end{tabular}

$\mathrm{T}=$ total; $\mathrm{x}=$ presença; $\mathrm{cl}=\mathrm{com} ; \mathrm{s} /=$ sern; reab, = reabsorçāo; CGMls = células gigantes multinucleadas inflamatórias

FIGURA 33 - Distribuição dos achados microscópios referentes aos fenômenos morfologicamente detectados nos animais do Grupo MD 1 


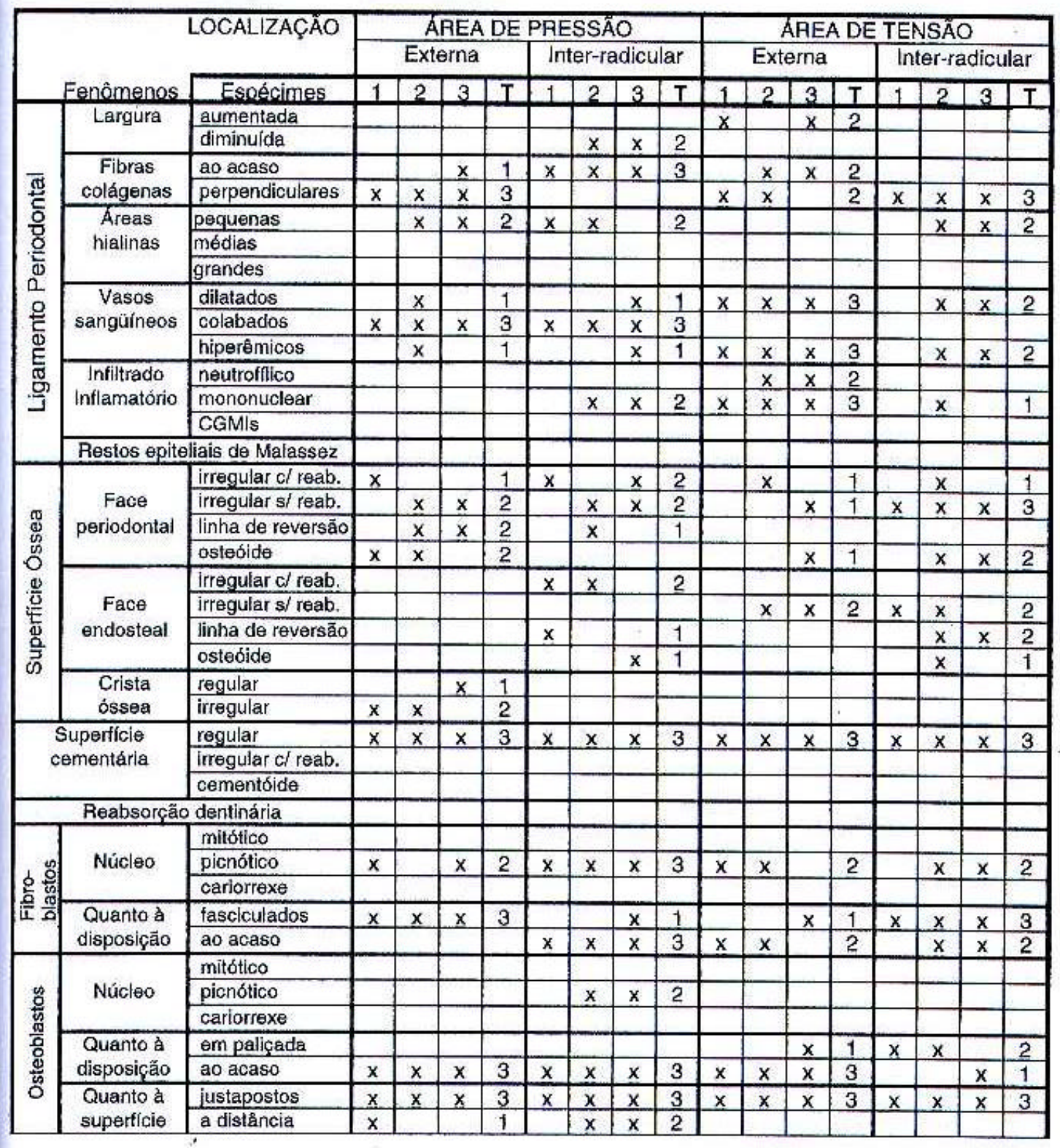


continuaçāo

\begin{tabular}{|c|c|c|c|c|c|c|c|c|c|c|c|c|c|c|c|c|c|c|}
\hline \multirow{7}{*}{ 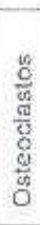 } & & & 1 & 2 & 3 & $T$ & 1 & 2 & 3 & $T$ & 1 & 2 & 3 & $T$ & 1 & 2 & 3 & $T$ \\
\hline & \multirow{3}{*}{ Núcleo(s) } & mitótico & & & & & & & & & & & & & & & & \\
\hline & & picnótico & & & & & & & & & & & & & & & & \\
\hline & & cariorrexe & & & & & & & & & & & & & & & & \\
\hline & \multirow{3}{*}{$\begin{array}{c}\text { Quanto } \\
\text { a } \\
\text { superticie }\end{array}$} & a distância & & & & & & $x$ & $x$ & 2 & $x$ & $x$ & & 2 & & $x$ & $x$ & 2 \\
\hline & & justapostos & $x$ & & $x$ & 2 & $x$ & $x$ & & 2 & & & & & & & & \\
\hline & & em lacunas & & $x$ & $x$ & 2 & & & & & & & & & & & & \\
\hline \multirow{7}{*}{ 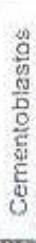 } & \multirow{3}{*}{ Núcleo } & mitólico & & & & & & & & & & & & & & & & \\
\hline & & pienótico & & & & & & & & & & & & & & & & \\
\hline & & cariorrexe & & & & & & & & & & & & & & & & \\
\hline & \multirow{2}{*}{$\begin{array}{l}\text { Quanto à } \\
\text { disposiçäo }\end{array}$} & em paliçada & & $x$ & $x$ & 2 & & & $x$ & 1 & & $x$ & & 1 & $x$ & $\mathrm{x}$ & & 2 \\
\hline & & ao acaso & $x$ & $x$ & $x$ & 3 & $x$ & $x$ & $x$ & 2 & $x$ & $x$ & $x$ & 3 & & & $x$ & 1 \\
\hline & \multirow{2}{*}{$\begin{array}{l}\text { Quanto a } \\
\text { superficie }\end{array}$} & justapostos & $x$ & $x$ & $x$ & 3 & $x$ & $x$ & $x$ & 3 & $x$ & $x$ & $x$ & 3 & $x$ & $x$ & $x$ & 3 \\
\hline & & a distância & & & & & & & & & & & & & & $x$ & $x$ & 2 \\
\hline \multirow{6}{*}{ 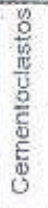 } & \multirow{3}{*}{ Núctoo(s) } & mitótico & & & & & & & & & & & & & & & & \\
\hline & & picnótico & & & & & & & & & & & & & & & & \\
\hline & & cariorrexe & & & & & & & & & & & & & & & & \\
\hline & \multirow{3}{*}{$\begin{array}{c}\text { Quanto } \\
\text { a } \\
\text { superticie }\end{array}$} & a distância & & & & & & & & & & & & & & & & \\
\hline & & justapostos & & & & & & & & & & & & & & & & \\
\hline & & nas lacunas & & & & & & & & & & & & & & & & \\
\hline
\end{tabular}

$T=$ total; $x=$ presença; $\mathrm{d}=\mathrm{com} ; \mathrm{S} /=$ sem; reab. = reabsorçāo; CGMls = células gigantes multinucleadas infiamatórias

FIGURA 34 - Distribuição dos achados microscópios referentes aos fenồmenos morfologicamente detectados nos animais do Grupo MD 3 


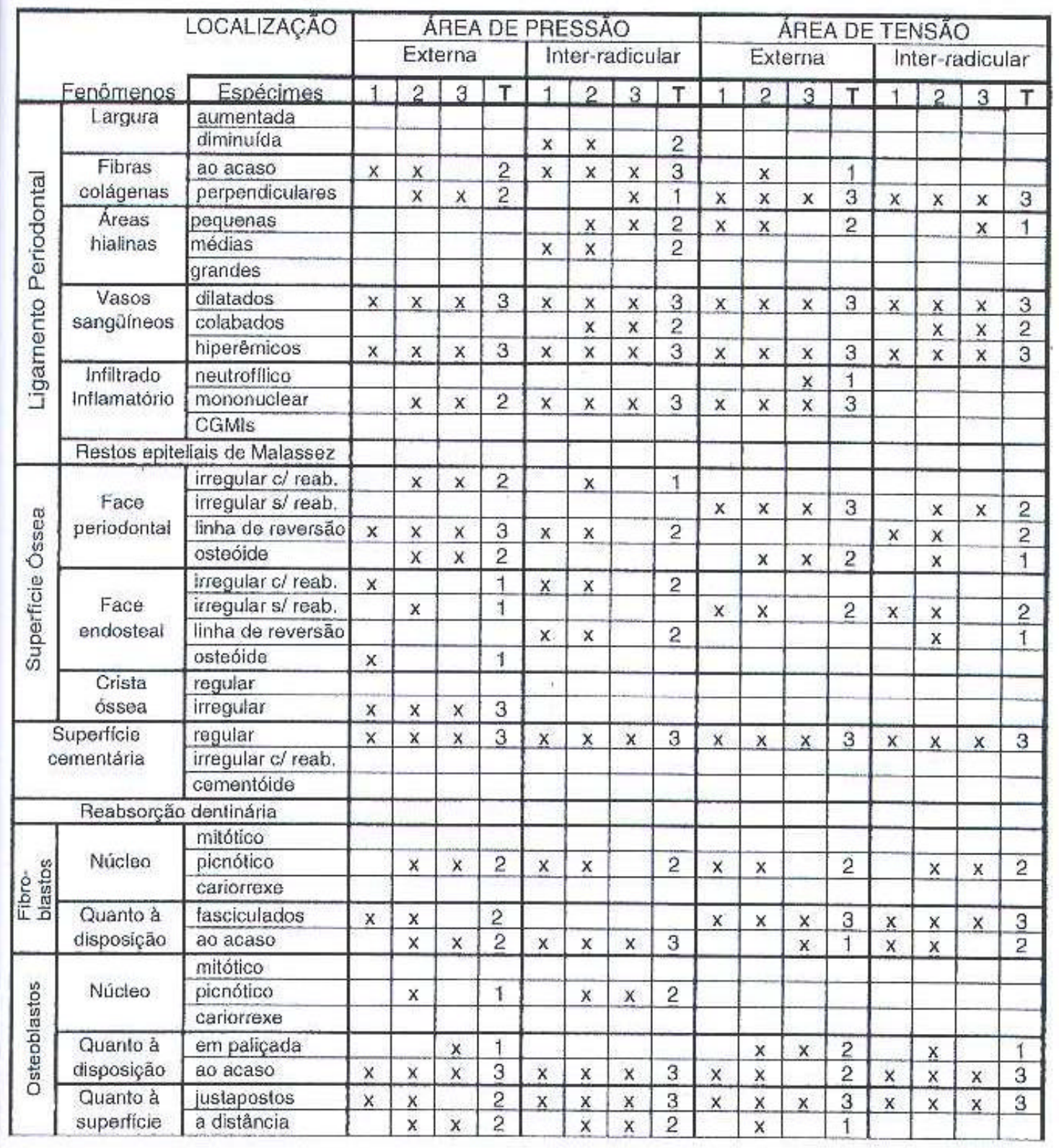


continuaçẫo

\begin{tabular}{|c|c|c|c|c|c|c|c|c|c|c|c|c|c|c|c|c|c|c|}
\hline & & & 1 & 2 & 3 & $T$ & 1 & 2 & 3 & $T$ & 1 & 2 & 3 & $T$ & 1 & 2 & 3 & $T$ \\
\hline \multirow{6}{*}{ 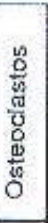 } & \multirow{3}{*}{ Núcleo(s) } & mitótico & & & & & & & & & & & & & & & & \\
\hline & & picnótico & & & & & & & & & & & & & & & & \\
\hline & & cariorrexe & & & & & & & & & & & & & & & & \\
\hline & \multirow{3}{*}{$\begin{array}{c}\text { Quanto } \\
\text { à } \\
\text { superticie } \\
\end{array}$} & a distância & $x$ & $x$ & & 2 & & $x$ & & 1 & & & & & & & & \\
\hline & & juslapostos & & & & & & $x$ & $x$ & 2 & & & & & & & & \\
\hline & & em lacunas & $x$ & $x$ & & 2 & & $x$ & & 1 & & & & & & & & \\
\hline \multirow{7}{*}{ 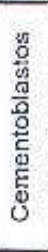 } & \multirow{3}{*}{ Núcleo } & mitótico & & & & & & & & & & & & & & & & \\
\hline & & picnótico & & & & & $x$ & & $x$ & 2 & & & & & & & & \\
\hline & & cariorrexe & & & & & & & & & & & & & & & & \\
\hline & \multirow{2}{*}{$\begin{array}{l}\text { Quanto à } \\
\text { disposiçäo }\end{array}$} & em palicada & & & & & & & & & $x$ & $x$ & $x$ & 3 & & $x$ & & 1 \\
\hline & & ao acaso & $x$ & $x$ & $x$ & 3 & $x$ & $x$ & $x$ & 3 & $x$ & $x$ & $x$ & 3 & $x$ & $x$ & $x$ & 3 \\
\hline & \multirow{2}{*}{$\begin{array}{l}\text { Quanto à } \\
\text { superticie }\end{array}$} & justapostos & $x$ & $x$ & $x$ & 3 & $x$ & $x$ & & 2 & $x$ & $x$ & $x$ & 3 & $x$ & $x$ & $x$ & 3 \\
\hline & & a distância & & & & & & $x$ & $x$ & 2 & & & & & & & & \\
\hline \multirow{6}{*}{ 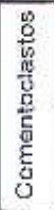 } & \multirow{3}{*}{ Nücleo(s) } & mitótico & & & & & & & & & & & & & & & & \\
\hline & & picnótico & & & & & & & & & & & & & & & & \\
\hline & & cariorrexe & & & & & & & & & & & & & & & & \\
\hline & \multirow{3}{*}{$\begin{array}{c}\text { Quanto } \\
\text { à } \\
\text { superficie }\end{array}$} & a diståncia & & & & & & & & & & & & & & & & \\
\hline & & justapostos & & & & & & & & & & & & & & & & \\
\hline & & nas lacunas & & & & & & & & & & & & & & & & \\
\hline
\end{tabular}

$T=$ total; $x=$ presença; $c /=c o m ; s /=$ sem; reab. = reabsorçäo; CGMls = células gigantes multinucleadas inflamatórias

FIGURA 35 - Distribuiçāo dos achados microscópios referentes aos fenômenos morfologicamente detectados nos animais do Grupo MD 5 
Resultados 94

\begin{tabular}{|c|c|c|c|c|c|c|c|c|c|c|c|c|c|c|c|c|c|c|}
\hline & & LOCALIZAÇĀO & & & REA & $\mathrm{DE}$ & SR & SS, & & & & & RE & $\mathrm{DE}$ & TE & $S A$ & & \\
\hline & & & & Ex & ina & & & $e r-r$ & dicl & & & Ext & rna & & & $e r-r$ & dicl & \\
\hline & Fenómenos & Espécimes & 1 & 2 & 3 & $T$ & 1 & 2 & 3 & $T$ & 1 & 2 & 3 & $T$ & 1 & 2 & 3 & $T$ \\
\hline & Largura & aumentada & & & & & & & & & $x$ & & $x$ & 2 & & & & \\
\hline & & diminuida & & & $x$ & 1 & $x$ & $x$ & & 2 & & & & & & & & \\
\hline & Fibras & ao acaso & $x$ & $x$ & $x$ & 3 & $x$ & $x$ & $x$ & 3 & & & & & & & & \\
\hline 蒠 & colàgenas & perpendiculares & & & & & & & & & $x$ & $\mathrm{x}$ & $\mathrm{x}$ & 3 & $\mathrm{x}$ & $x$ & $x$ & 3 \\
\hline 등 & Areas & pequenas & $x$ & $x$ & & 2 & & & & & & $\mathrm{x}$ & $x$ & 2 & & $x$ & $x$ & 2 \\
\hline 8 & hialinas & médias & & & & & $x$ & $x$ & $x$ & 3 & & & & & & & & \\
\hline 0 & & grandes & & & & & & & $\mathrm{x}$ & 1 & & & & & & & & \\
\hline 8 & Vasos & dilatados & $x$ & $x$ & & 2 & & $x$ & $x$ & 2 & $x$ & $x$ & $x$ & 3 & $x$ & & $x$ & 2 \\
\hline 苞 & sangüineos & colabados & $x$ & $x$ & $x$ & 3 & $x$ & $x$ & $x$ & 3 & & & & & $\mathrm{x}$ & $x$ & & 2 \\
\hline हू & & hiperêmicos & $x$ & $\mathrm{x}$ & & 2 & & $x$ & $x$ & 2 & $x$ & $x$ & $x$ & 3 & $\mathrm{x}$ & & $\mathrm{x}$ & 2 \\
\hline 菢 & Infilltrado & neutrofilico & & & & & & & & & & & & & & & & \\
\hline & Infiamatório & mononuclear & & & & & $\mathrm{x}$ & $x$ & $\mathrm{x}$ & 3 & $\mathrm{x}$ & $x$ & & 2 & & & & \\
\hline & & CGMIs & & & & & & & & & & & & & & & & \\
\hline & Restos epite & fiais de Malassez & & & & & & & & & & & & & & & & \\
\hline & & iirregular c/ reab. & & & $x$ & 1 & & & & & $\mathrm{x}$ & $\mathrm{x}$ & $x$ & 3 & $x$ & & $x$ & 2 \\
\hline & Face & irregular s/ reab. & $\mathrm{x}$ & $\mathrm{x}$ & $x$ & 3 & $\mathrm{x}$ & $x$ & $x$ & 3 & $\mathrm{x}$ & $x$ & & 2 & $x$ & $x$ & $x$ & 3 \\
\hline $\mathbb{g}$ & periodontal & \begin{tabular}{|l|} 
linha de reversăo \\
\end{tabular} & & $\mathrm{x}$ & $x$ & 2 & & $x$ & $x$ & 2 & & & & & & $x$ & $x$ & 2 \\
\hline ס & & osteóide & & & & & & & & & & & & & & & & \\
\hline (1) & & irregular c/ reab. & & & & & $x$ & $x$ & $x$ & 3 & & & & & & & & \\
\hline 选 & Face & irregular s/ reab. & $x$ & $x$ & $\mathrm{x}$ & 3 & & & & & $x$ & $x$ & & 2 & $x$ & & $x$ & 2 \\
\hline बाँ & endosteal & linha de reversăo & & & $x$ & 1 & & $x$ & & 1 & & & & & $\mathrm{x}$ & $x$ & $x$ & 3 \\
\hline क & & osteóide & & & & & & & & & & & & & & & & \\
\hline & Crista & regular & & & $x$ & 1 & & & & & & & & & & & & \\
\hline & óssea & irregular & $x$ & $x$ & & 2 & & & & & & & & & & & & \\
\hline & Superficie & regular & $x$ & $x$ & $\bar{x}$ & 3 & $x$ & $x$ & $x$ & 3 & $x$ & $x$ & $x$ & 3 & $\mathrm{x}$ & $x$ & $x$ & 3 \\
\hline & ementária & irregular c/ reab. & & & & & & & & & & & & & & & & \\
\hline & & cementóide & & & & & & & & & & & & & & & & \\
\hline & Reabsorçăo & dentinária & & & & & & & & & & & & & & & & \\
\hline & & mitótico & & & & & & & & & & & & & & & & \\
\hline & Núcleo & picnótico & $x$ & $x$ & & 2 & $x$ & $x$ & $x$ & 3 & & $x$ & & 1 & & $x$ & $x$ & 2 \\
\hline 인음 & & cariorrexe & & & & & & & & & & & & & & & & \\
\hline 茫 $\frac{\pi}{a}$ & Quanto à & fasciculados & $x$ & $x$ & $x$ & 3 & & & & & $\mathrm{x}$ & $x$ & $x$ & 3 & $x$ & $x$ & $x$ & 3 \\
\hline & disposiçăo & \begin{tabular}{|l|} 
ao acaso \\
\end{tabular} & & $x$ & $x$ & 2 & $x$ & $x$ & $x$ & 3 & $x$ & $x$ & $x$ & 3 & $\bar{x}$ & $x$ & $x$ & 3 \\
\hline & & milólico & & & & & & & & & & & & & & & & \\
\hline$\stackrel{\mathscr{2}}{\circ}$ & Núcleo & picnótico & & & & & & & & & & & & & & & & \\
\hline 莺 & & cariorrexe & & & & & & & & & & & & & & & & \\
\hline 뭉 & Quanto $\hat{a}$ & em paliçada & & & $\mathrm{x}$ & 1 & & & $x$ & 1 & & $\mathrm{x}$ & & 1 & $x$ & $x$ & & 2 \\
\hline$\frac{d}{5}$ & disposiçăo & ao acaso & $x$ & $\mathrm{x}$ & $x$ & 3 & $x$ & $x$ & $x$ & 3 & $x$ & $x$ & $x$ & 3 & $x$ & $\mathrm{x}$ & $x$ & 3 \\
\hline & Quanto à & justapostos & $x$ & $\mathrm{x}$ & $x$ & 3 & $x$ & $x$ & $x$ & 3 & $x$ & $x$ & $x$ & 3 & $x$ & $x$ & $x$ & 3 \\
\hline & superficie & a distância & & & & & & & & & & & & & & & & \\
\hline
\end{tabular}

continua 
continuação

\begin{tabular}{|c|c|c|c|c|c|c|c|c|c|c|c|c|c|c|c|c|c|c|}
\hline & & & 1 & 2 & 3 & $T$ & 1 & 2 & 3 & $\mathrm{~T}$ & 1 & 2 & 3 & $T$ & 1 & 2 & 3 & $T$ \\
\hline \multirow{6}{*}{ 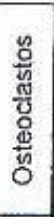 } & \multirow{3}{*}{ Núcleo(s) } & mitótico & & & & & & & & & & & & & & & & - \\
\hline & & picnótico & & & & & & & & & & & & & & & & \\
\hline & & cariorrexe & & & & & & & & & & & & & & & & \\
\hline & \multirow{3}{*}{$\begin{array}{c}\text { Quanto } \\
\text { à } \\
\text { superficie }\end{array}$} & a diståncia & & & & & & $x$ & $x$ & 2 & $x$ & & & 1 & $x$ & & $x$ & 2 \\
\hline & & Justapostos & & $x$ & $x$ & 2 & $x$ & $x$ & & 2 & $x$ & $x$ & & 2 & & & & \\
\hline & & em lacunas & $x$ & $x$ & & 2 & & & & & $x$ & $x$ & $x$ & 3 & & & & \\
\hline \multirow{7}{*}{ 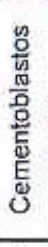 } & \multirow{3}{*}{ Núcleo } & mitólico & & & & & & & & & & & & & & & & \\
\hline & & pienótico & & & & & & & & & & & & & & & & \\
\hline & & cariorrexe & & & & & & & & & & & & & & & & \\
\hline & \multirow{2}{*}{$\begin{array}{l}\text { Quanto à } \\
\text { disposiçăo }\end{array}$} & em paliçada & $x$ & $x$ & & 2 & & & & & & $x$ & $x$ & 2 & $x$ & $x$ & $x$ & 3 \\
\hline & & ao acaso & $x$ & $x$ & $x$ & 3 & $x$ & $x$ & $x$ & 3 & $x$ & $x$ & & 2 & $x$ & $x$ & & 2 \\
\hline & \multirow{2}{*}{$\begin{array}{l}\text { Quanto à } \\
\text { superficie }\end{array}$} & justapostos & $x$ & $x$ & $x$ & 3 & $x$ & $x$ & $x$ & 3 & $x$ & $x$ & $x$ & 3 & $x$ & $x$ & $x$ & 3 \\
\hline & & a dislåncla & & & & & & & & & & & & & & & & \\
\hline \multirow{6}{*}{ 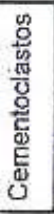 } & \multirow{3}{*}{ Núcleo(s) } & mitótico & & & & & & & & & & & & & & & & \\
\hline & & picnótico & & & & & & & & & & & & & & & & \\
\hline & & cariorrexe & & & & & & & & & & & & & & & & \\
\hline & \multirow{3}{*}{$\begin{array}{c}\text { Quanto } \\
\text { à } \\
\text { superficie }\end{array}$} & a distância & & & & & & & & & & & & & & & & \\
\hline & & justapostos & & & & & & & & & & & & & & & & \\
\hline & & nas lacunas & & & & & & & & & & & & & & & - & \\
\hline
\end{tabular}

$T=$ total; $x=$ presença; $c l=$ com; $s /=$ sem; reab. = reabsorção; CGMls = células gigantes multinucleadas inflamatórias

FIGURA 36 - Distribuiçăo dos achados microscópios referentes aos fenômenos morfologicamente detectados nos animais do Grupo OV 1 
Resultados 96

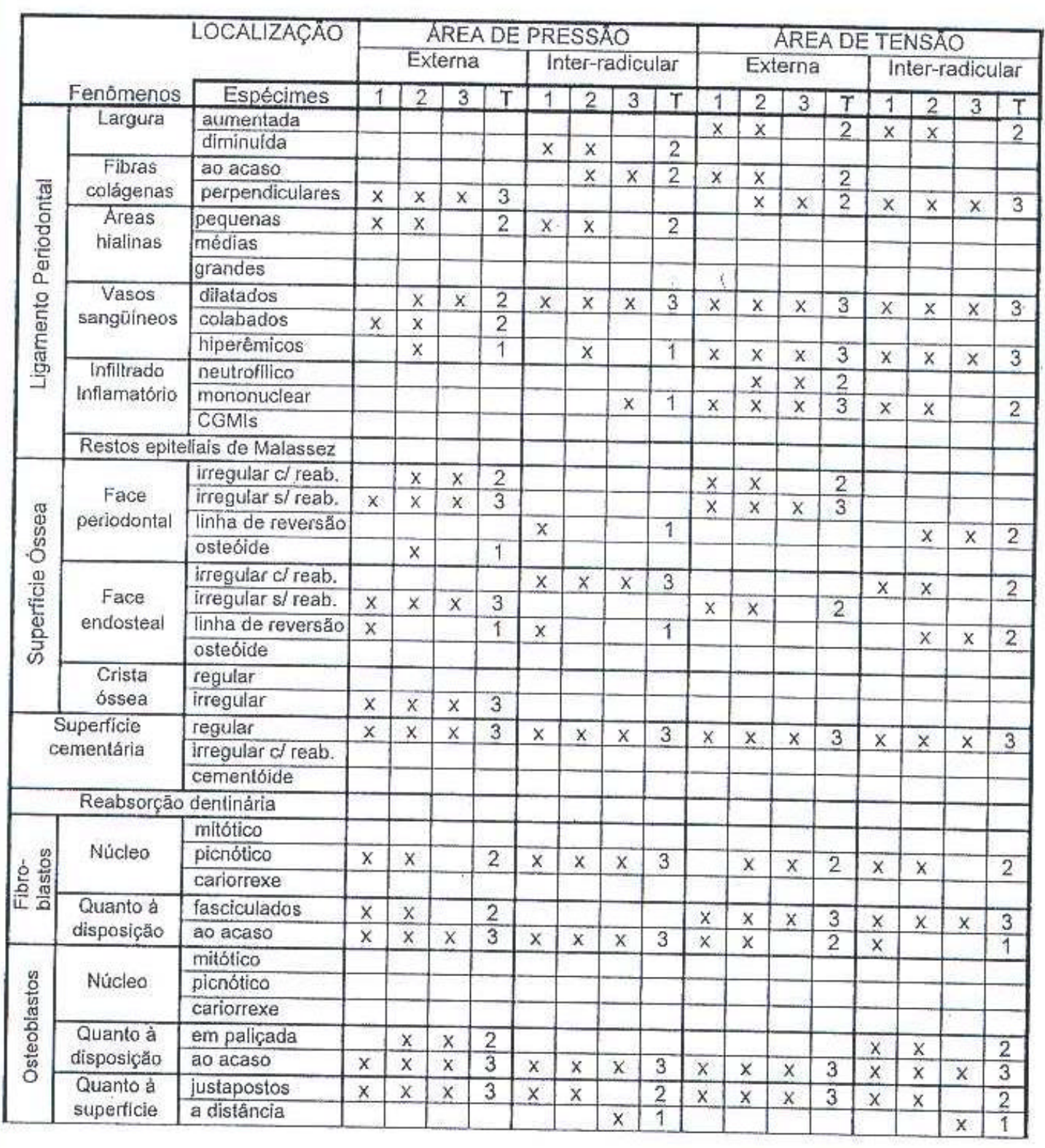

continua 
continuação

\begin{tabular}{|c|c|c|c|c|c|c|c|c|c|c|c|c|c|c|c|c|c|c|}
\hline & & & 1 & 2 & 3 & $T$ & 1 & 2 & 3 & $T$ & 1 & 2 & 3 & $T$ & 1 & 2 & 3 & $T$ \\
\hline \multirow{6}{*}{ 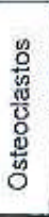 } & \multirow{3}{*}{ Núcleo(s) } & mitótico & & & & & & & & & & & & & & & & \\
\hline & & picnótico & & & & & & & & & & & & & & & & \\
\hline & & cariorrexe & & & & & & & & & & & & & & & & \\
\hline & \multirow{3}{*}{$\begin{array}{c}\text { Quanto } \\
\text { à } \\
\text { superticie }\end{array}$} & a dislåncia & & $x$ & $x$ & 2 & & & & & & & & & $x$ & & & 1 \\
\hline & & justapostos & & & & & $x$ & $\mathrm{x}$ & $x$ & 3 & $x$ & $x$ & & 2. & & & & \\
\hline & & em lacunas & & & & & $x$ & $\mathrm{x}$ & & 2 & $\mathrm{x}$ & $x$ & & 2 & & & & \\
\hline \multirow{7}{*}{ 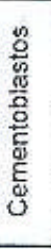 } & \multirow{3}{*}{ Núcleo } & mitótico & & & & & & & & & & & & & & & & \\
\hline & & pícnótico & & & & & & & & & & & & & & & & \\
\hline & & cariorrexe & & & & & & & & & & & & & & & & \\
\hline & \multirow{2}{*}{$\begin{array}{l}\text { Quanto à } \\
\text { disposiçä́o }\end{array}$} & em paliçada & $x$ & $x$ & $x$ & 3 & & $x$ & $x$ & 2 & $x$ & $x$ & $x$ & 3 & $x$ & $x$ & $x$ & 3 \\
\hline & & ao acaso & & $\mathrm{x}$ & $x$ & 2 & $x$ & $x$ & & 2 & $x$ & $x$ & $x$ & 3 & & $x$ & $x$ & 2 \\
\hline & \multirow{2}{*}{$\begin{array}{l}\text { Quanto à } \\
\text { supericie }\end{array}$} & justapostos & $x$ & $x$ & $x$ & 3 & $x$ & $x$ & & 2 & $x$ & $x$ & $x$ & 3 & $x$ & $x$ & $x$ & 3 \\
\hline & & a distância & & & & & & & $x$ & 1 & & & & & & & & \\
\hline \multirow{6}{*}{ 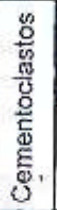 } & \multirow{3}{*}{ Núcleo(s) } & mitótico & & & & & & & & & & & & & & & & \\
\hline & & picnótico & & & & & & & & & & & & & & & & \\
\hline & & cariorrexe & & & & & & & & & & & & & & & & \\
\hline & \multirow{3}{*}{$\begin{array}{c}\text { Quanto } \\
\text { à } \\
\text { superficie }\end{array}$} & a distáncia & & & & & & & & & & & & & & & & \\
\hline & & justapostos & & & & & & & & & & & & & & & & \\
\hline & & nas lacunas & & & & & & & & & & & & & & & & \\
\hline
\end{tabular}

$\mathrm{T}=$ total; $\mathrm{x}=$ presença; $\mathrm{cl}=\mathrm{com} ; \mathrm{sl}=\mathrm{sem} ;$ reab. = reabsorçáo; CGMls = células gigantes multinucleadas inflamatórias

FIGURA 37 - Distribuição dos achados microscópios referentes aos fenômenos morfologicamente detectados nos animais do Grupo oV 3 


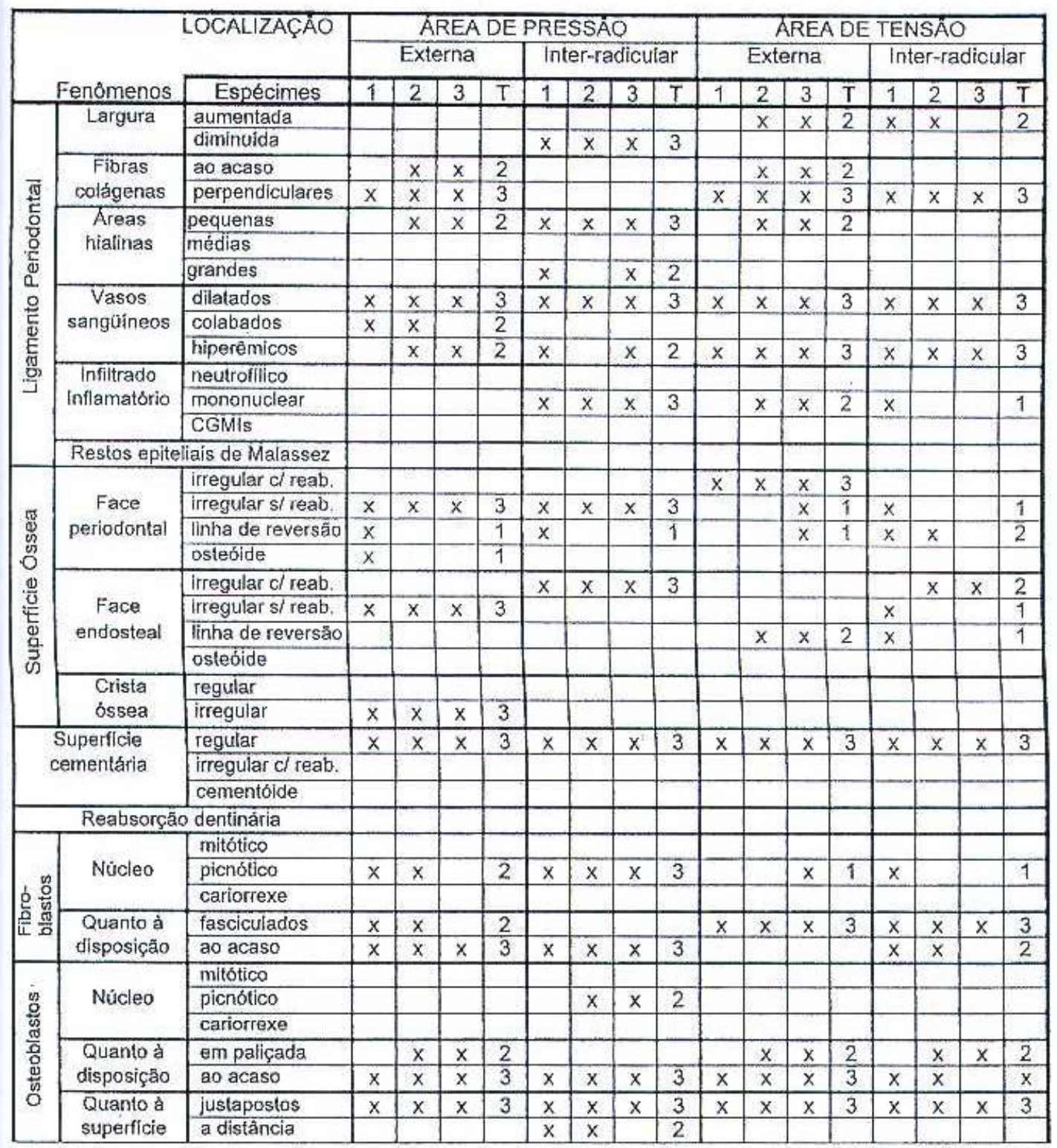




\section{continuação}

\begin{tabular}{|c|c|c|c|c|c|c|c|c|c|c|c|c|c|c|c|c|c|c|}
\hline & & & 1 & 2 & 3 & $\bar{T}$ & 1 & 2 & 3 & $T$ & 1 & 2 & 3 & $T$ & 1 & 2 & 3 & $T$ \\
\hline \multirow{6}{*}{ 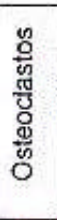 } & \multirow{3}{*}{ Núcleo(s) } & mitótico & & & & & & & & & & & & & & & & \\
\hline & & picnótico & & & & & & & & & & & & & & & & \\
\hline & & cariorrexe & & & & & & & & & & & & & & & & \\
\hline & \multirow{3}{*}{$\begin{array}{c}\text { Quanto } \\
\text { a } \\
\text { superficie }\end{array}$} & a distância & & & & & & & & & & & & & & $x$ & $x$ & 2 \\
\hline & & justapostos & & & & & $x$ & $x$ & $x$ & 3 & $x$ & $x$ & $x$ & 3 & & & & \\
\hline & & em lacunas & & & & & $x$ & $x$ & $x$ & 3 & & $x$ & & 1 & & & & \\
\hline \multirow{7}{*}{ 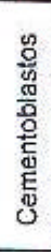 } & \multirow{3}{*}{ Núcleo } & mitótico & & & & & & & & & & & & & & & & \\
\hline & & picnótico & & & $x$ & 1 & & $x$ & $x$ & 2 & & & & & & & & \\
\hline & & cariorrexe & & & & & & & & & & & & & & & & \\
\hline & \multirow{2}{*}{$\begin{array}{l}\text { Quanto ả } \\
\text { disposiçăo }\end{array}$} & em paliçada & & $x$ & $x$ & 2 & & & & & & $\mathrm{x}$ & $x$ & 2 & $x$ & $x$ & & 2 \\
\hline & & ao acaso & $x$ & $x$ & & 2 & $x$ & $x$ & $x$ & 3 & $x$ & $x$ & $x$ & 3 & $x$ & $x$ & $x$ & 3 \\
\hline & \multirow{2}{*}{$\begin{array}{l}\text { Quanto d } \\
\text { superficie }\end{array}$} & justapostos & $x$ & $x$ & $x$ & 3 & $x$ & $x$ & & 2 & $x$ & $x$ & $x$ & 3 & $x$ & $x$ & $x$ & 3 \\
\hline & & a distância & & & & & & $\mathrm{x}$ & $x$ & 2 & & & & & & & & \\
\hline \multirow{6}{*}{ 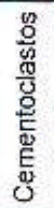 } & \multirow{3}{*}{ Núcleo(s) } & mitótico & & & & & & & & & & & & & & & & \\
\hline & & picnótico & & & & & & & & & & & & & & & & \\
\hline & & cariorrexe & & & & & & & & & & & & & & & & \\
\hline & \multirow{3}{*}{$\begin{array}{c}\text { Quanto } \\
\text { à } \\
\text { superficie }\end{array}$} & a distáncia & & & & & & & & & & & & & & & & \\
\hline & & justapostos & & & & & & & & & & & & & & & & \\
\hline & & nas lacunas & & & & & & & & & & & & & & & & \\
\hline
\end{tabular}

$T=$ total; $x=$ presença; $c l=c o m ; s /=s e m ; r e a b,=$ reabsorção; CGMls = células gigantes multinucleadas inflamatórias

FIGURA 38 - Distribuição dos achados microscópios referentes aos fenômenos morfologicamente detectados nos animais do Grupo OV 5 


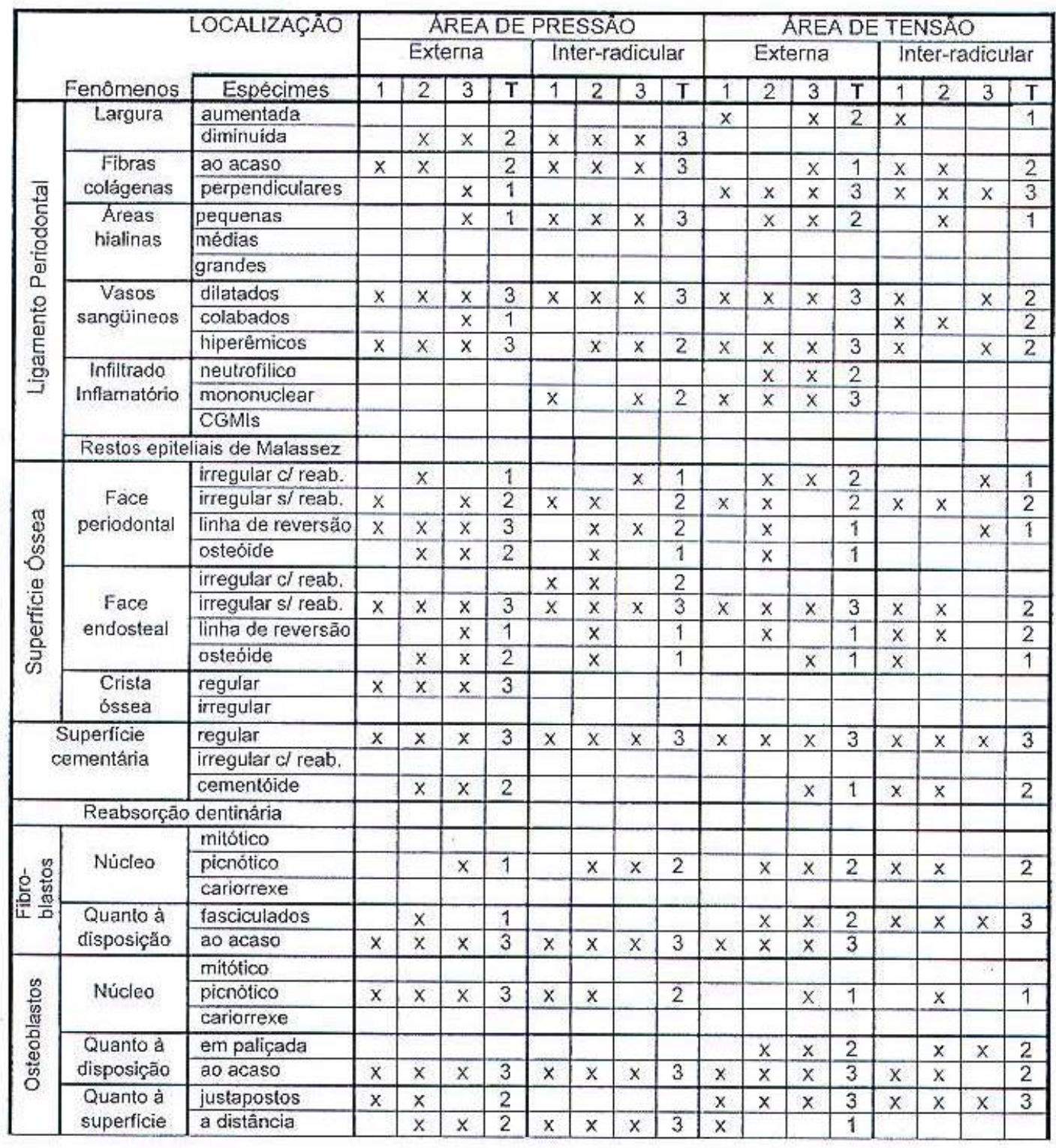


continuação

\begin{tabular}{|c|c|c|c|c|c|c|c|c|c|c|c|c|c|c|c|c|c|c|}
\hline & & & 1 & 2 & 3 & $T$ & 1 & 2 & 3 & $T$ & 1 & 2 & 3 & $T$ & 1 & 2 & 3 & $\bar{T}$ \\
\hline \multirow{6}{*}{ 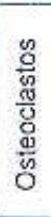 } & \multirow{3}{*}{ Núcleo(s) } & mitótico & & & & & & & & & & & & & & & & \\
\hline & & picnótico & & & & & & & & & & & & & & & & \\
\hline & & cariorrexe & & & & & & & & & & & & & & & & \\
\hline & \multirow{3}{*}{$\begin{array}{c}\text { Quanto } \\
\text { à } \\
\text { superficie }\end{array}$} & a distăncia & & $x$ & & 1 & & & & & & $x$ & $x$ & 1 & & & $\bar{x}$ & 1 \\
\hline & & justapostos & & $x$ & & 1 & & $x$ & $\mathrm{x}$ & 2 & & & $x$ & 1 & & & & \\
\hline & & em lacunas & & & & & $\mathrm{x}$ & & & 1 & & & & & & & & \\
\hline \multirow{7}{*}{ 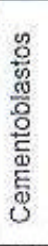 } & \multirow{3}{*}{ Núcleo } & mitótico & & & & & & & & & & & & & & & & \\
\hline & & picnótico & & & $\mathrm{x}$ & 1 & & $x$ & $x$ & 2 & & & $x$ & 1 & & & & \\
\hline & & cariorrexe & & & & & & & & & & & & & & & & \\
\hline & \multirow{2}{*}{$\begin{array}{l}\text { Quanto à } \\
\text { disposiçăa }\end{array}$} & em paliçada & & & $x$ & 1 & & & $x$ & 1 & $x$ & $x$ & & 2 & $x$ & $x$ & & 2 \\
\hline & & ao acaso & $x$ & $\mathrm{x}$ & & 2 & $x$ & $x$ & & 2 & & & $x$ & 1 & & $x$ & $x$ & 2 \\
\hline & \multirow{2}{*}{$\begin{array}{l}\text { Quanto à } \\
\text { superficie }\end{array}$} & justapostos & $x$ & & $x$ & 2 & & $x$ & $x$ & 2 & $x$ & $x$ & $x$ & 3 & $x$ & $x$ & $x$ & 3 \\
\hline & & a distância & & $\mathrm{x}$ & & 1 & $x$ & & & 1 & & & & & & & & \\
\hline \multirow{6}{*}{ 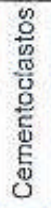 } & \multirow{3}{*}{ Núcleo(s) } & mitótico & & & & & & & & & & & & & & & & \\
\hline & & picnótico & & & & & & & & & & & & & & & & \\
\hline & & cariorrexe & & & & & & & & & & & & & & & & \\
\hline & \multirow{3}{*}{$\begin{array}{c}\text { Quanto } \\
\text { a } \\
\text { superficie }\end{array}$} & a distância & & & & & & & & & & & & & & & & \\
\hline & & justapostos & & & & & & & & & & & & & & & & \\
\hline & & nas lacunas & & & & & & & & & & & & & & & & \\
\hline
\end{tabular}

$\mathrm{T}=$ total; $\mathrm{x}=$ presença; $\mathrm{cl}=\mathrm{com} ; \mathrm{s} /=\mathrm{sem} ;$ reab. = reabsorção; CGMls = células gigantes multinucleadas inflamatórias

FIGURA 39 - Distribuiçăo dos achados microscópios referentes aos fenômenos morfologicamente detectados nos animais do Grupo OS 1 


\begin{tabular}{|c|c|c|c|c|c|c|c|c|c|c|c|c|c|c|c|c|c|c|}
\hline & & LOCALIZAÇÁO & & & REA & $\overline{\mathrm{DE}}$ & R! & $S S A$ & & & & & $\overline{R E}$ & $\overline{D P}$ & $\overline{T E}$ & $\widehat{S A}$ & & \\
\hline & & & & Ext & rna & & & $e r-\Gamma 2$ & dict & & & Ext & ma & & & $e r-r$ & dic & \\
\hline & Fenómenos & Espécimes & 1 & 2 & 3 & $T$ & 1 & 2 & 3 & $\mathrm{~T}$ & 1 & 2 & 3 & $T$ & 1 & 2 & 3 & $T$ \\
\hline & Largura & aumentada & & & & & & & & & & $x$ & $x$ & 2 & & & $x$ & 1 \\
\hline & & diminuida & & & & & & $\mathrm{x}$ & $\mathrm{x}$ & 2 & & & & & & & & \\
\hline & Fibras & ao acaso & & $x$ & & 1 & $x$ & $x$ & & 2 & & $x$ & $x$ & 2 & $x$ & & & 1 \\
\hline & colágenas & perpendiculares & $x$ & $\mathrm{x}$ & $x$ & 3 & & $x$ & $x$ & 2 & $x$ & & & 1 & $x$ & $x$ & $x$ & 3 \\
\hline 돔 & Areas & pequenas & & & $\mathrm{x}$ & 1 & $x$ & $x$ & & 2 & & & & & & $x$ & & 1 \\
\hline 은 & hialinas & médias & & & & & & & & & & & & & & & & \\
\hline 0 & & grandes & & & & & & & & & & & & & & & & \\
\hline 8 & Vasos & dilatados & $x$ & $x$ & & 2 & $x$ & & $x$ & 2 & $x$ & $x$ & $x$ & 3 & $\mathrm{x}$ & $\mathrm{x}$ & & 2 \\
\hline d) & sangüineos & colabados & & $x$ & $\mathrm{x}$ & 2 & & $x$ & $x$ & 2 & & & & & & & & \\
\hline E & & hiperêmicos & $x$ & $x$ & & 2 & $\mathrm{x}$ & & $x$ & 2 & $x$ & $\mathrm{x}$ & $x$ & 3 & $x$ & $x$ & & 2 \\
\hline & Infilltrado & neutrofilico & & & & & & & & & & & $x$ & 1 & & & & \\
\hline & Inflamatório & mononuclear & & & $x$ & 1 & $x$ & $x$ & & 2 & $x$ & $\mathrm{x}$ & $x$ & 3 & & & & \\
\hline & & CGMIs & & & & & & & & & & & & & & & & \\
\hline & Restos epito & liais de Malassez & & & & & & & & & & & & & & & & \\
\hline & & irregular c/ reab. & & $x$ & $x$ & 2 & $x$ & $x$ & $\mathrm{x}$ & 3 & $x$ & & $x$ & 2 & & & $x$ & 1 \\
\hline & Face & irregular s/ reab. & $x$ & $x$ & & 2 & & $x$ & $x$ & 2 & & $\mathrm{x}$ & & 1 & $x$ & $x$ & $\mathrm{x}$ & 3 \\
\hline & periodontal & linha de teversão & $\mathrm{x}$ & $x$ & & 2 & $x$ & & & 1 & & $x$ & & 1 & & $x$ & & 1 \\
\hline 変 & & osteóide & $\mathrm{x}$ & $x$ & & 2 & $x$ & & & 1 & & $\mathrm{x}$ & & 1 & $x$ & $x$ & & 2 \\
\hline 0 & & irregular c/ reab. & & & & & $x$ & & $x$ & 2 & & & & & & & & \\
\hline$\frac{\omega}{5}$ & Face & irregular s/ reab. & & & & & & $x$ & & 1 & & $\mathrm{x}$ & $x$ & 2 & $\mathrm{x}$ & $\mathrm{x}$ & & 2 \\
\hline$\frac{5}{0}$ & endosteal & linha de reversăo & & & & & & $x$ & & 1 & & & & & & $x$ & $x$ & 2 \\
\hline 을 & & osteóide & & & & & & $x$ & & 1 & & & & & & $x$ & & 1 \\
\hline & Crista & regular & & $\mathrm{x}$ & $x$ & 2 & & & & & & & & & & & & \\
\hline & óssea & irregular & $x$ & & & 1 & & & & & & & & & & & & \\
\hline & Superficie & regular & $\mathrm{x}$ & $x$ & $x$ & 3 & $x$ & $\mathrm{x}$ & $x$ & 3 & $x$ & $\mathrm{x}$ & $\mathrm{x}$ & 3 & $x$ & $x$ & $x$ & 3 \\
\hline & ementária & \begin{tabular}{|l} 
irregular c/ reab. \\
\end{tabular} & & & & & & & & & & & & & & & & \\
\hline & & cementóide & & & & & & & & & & & & & & & & \\
\hline & Reabsorçāo & dentinária & & & & & & & & & & & & & & & & \\
\hline & & mitótico & & & & & & & & & & & & & & & & \\
\hline & Núcleo & picnótico & $x$ & $x$ & $x$ & 3 & $x$ & $x$ & $x$ & 3 & $x$ & & $x$ & 2 & $x$ & & & 1 \\
\hline 号学 & & cariorrexe & & & & & & & & & & & & & & & & \\
\hline 希高 & Quanto à & fasciculados & $\mathrm{x}$ & & $x$ & 2 & & & & & & & $x$ & 1 & $x$ & $x$ & $x$ & 3 \\
\hline & disposiç̧āo & ao acaso & & $x$ & & 1 & $x$ & $x$ & $x$ & 3 & $x$ & $\mathrm{x}$ & & 2 & & & $\mathrm{x}$ & 1 \\
\hline & & mitótico & & & & & & & & & & & & & & & & \\
\hline$\stackrel{\infty}{8}$ & Núcleo & picnótico & & & & & $x$ & $\mathrm{x}$ & & 2 & & & & & & & & \\
\hline 总 & & cariorrexe & & & & & & & & & & & & & & & & \\
\hline 응 & Quanto à & em paliçada & & & & & & & & & $\mathrm{x}$ & $x$ & & 2 & $x$ & $x$ & $x$ & 3 \\
\hline$\frac{\omega}{3}$ & disposição & ao acaso & & $\mathrm{x}$ & $\mathrm{x}$ & 2 & $x$ & $x$ & $x$ & 3 & & $x$ & $\mathrm{x}$ & 2 & & & & \\
\hline & Quanto à & justapostos & $x$ & $x$ & $x$ & 3 & $x$ & $x$ & & 2 & $x$ & $x$ & $x$ & 3 & $x$ & $x$ & $x$ & 3 \\
\hline & superficie & a distância & & $x$ & $x$ & 2 & & $x$ & $x$ & 2 & & & & & & $x$ & & 1 \\
\hline
\end{tabular}


continuação

\begin{tabular}{|c|c|c|c|c|c|c|c|c|c|c|c|c|c|c|c|c|c|c|}
\hline & & & 1 & 2 & 3 & $T$ & 1 & 2 & 3 & $T$ & 1 & 2 & 3 & $T$ & 1 & 2 & 3 & $T$ \\
\hline \multirow{6}{*}{$\begin{array}{l}0 \\
0 \\
0 \\
0 \\
0 \\
0 \\
0 \\
0 \\
0 \\
0\end{array}$} & \multirow{3}{*}{ Núcleo(s) } & mitótico & & & & & & & & & & & & & & & & \\
\hline & & picnótico & & & & & & & & & & & & & & & & \\
\hline & & cariorrexe & & & & & & & & & & & & & & & & \\
\hline & \multirow{3}{*}{$\begin{array}{c}\text { Quanto } \\
\text { à } \\
\text { superficie } \\
\end{array}$} & a distância & & & $x$ & 1 & & & & & $x$ & & $x$ & 2 & & & $x$ & 1 \\
\hline & & justapostos & & $x$ & $\mathrm{x}$ & 2 & $x$ & $\mathrm{x}$ & $x$ & 3 & & & & & & & & \\
\hline & & em lacunas & & & & & & $x$ & $x$ & 2 & & & & & & & & \\
\hline \multirow{7}{*}{ 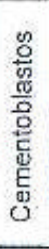 } & \multirow{3}{*}{ Núcleo } & mitśtico & & & & & & & & & & & & & & & & \\
\hline & & pienótico & & & & & & & & & & & & & & & & \\
\hline & & cariorrexe & & & & & & & & & & & & & & & & \\
\hline & \multirow{2}{*}{$\begin{array}{l}\text { Quanto à } \\
\text { disposiçäo }\end{array}$} & em paliçada & $x$ & & & 1 & & & & & $x$ & $x$ & & 2 & $x$ & $x$ & $x$ & 3 \\
\hline & & ao acaso & & $x$ & $x$ & 2 & $x$ & $x$ & $x$ & 3 & & $x$ & $\mathrm{x}$ & 2 & & & & \\
\hline & \multirow{2}{*}{$\begin{array}{l}\text { Quanto à } \\
\text { superficie }\end{array}$} & justapostos & $x$ & $x$ & & 2 & & $x$ & $x$ & 2 & $x$ & $x$ & $x$ & 3 & $x$ & $x$ & $x$ & 3 \\
\hline & & a distância & & $x$ & $x$ & 2 & $\mathrm{x}$ & $x$ & & 2 & & & & & & & & \\
\hline \multirow{6}{*}{ 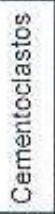 } & \multirow{3}{*}{ Núcleo(s) } & mitótico & & & & & & & & & & & & & & & & \\
\hline & & picnótico & & & & & & & & & & & & & & & & \\
\hline & & cariorrexe & & & & & & & & & & & & & & & & \\
\hline & \multirow{3}{*}{$\begin{array}{c}\text { Quanto } \\
\text { à } \\
\text { superficie }\end{array}$} & a distância & & & & & & & & & & & & & & & & \\
\hline & & justapostos & & & & & & & & & & & & & & & & \\
\hline & & nas lacunas & & & & & & & & & & & & & & & & \\
\hline
\end{tabular}

$T=$ total; $x=$ presença; $c /=c o m ; s /=$ sem; reab. = reabsorção; CGMls = células gigantes multinucleadas inflamatórias

FIGURA 40 - Distribuição dos achados microscópios referentes aos fenômenos morfologicamente detectados nos animais do Grupo OS 3 


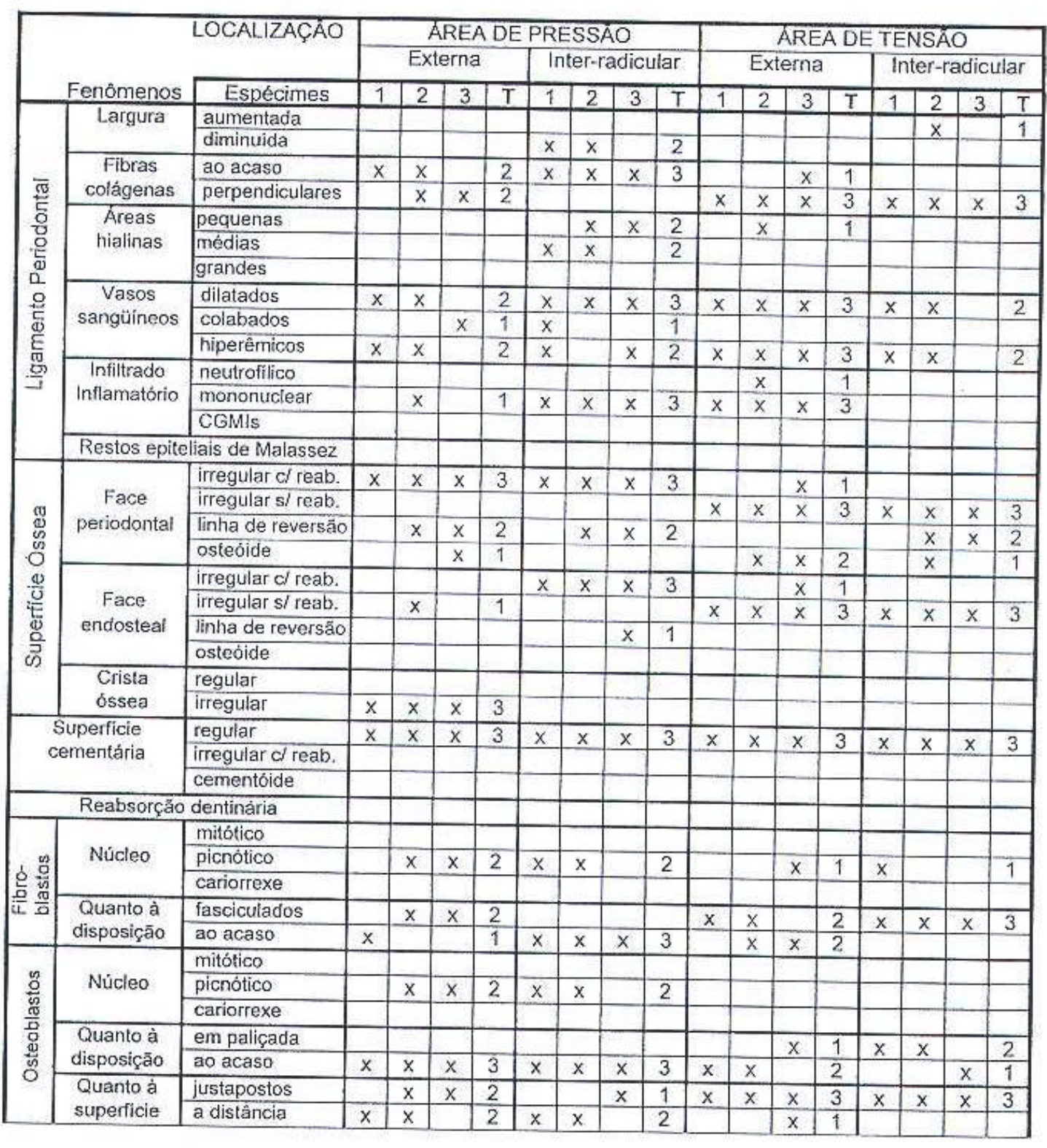


continuaçăo

\begin{tabular}{|c|c|c|c|c|c|c|c|c|c|c|c|c|c|c|c|c|c|c|}
\hline & & & 1 & 2 & 3 & $T$ & 1 & 2 & 3 & $T$ & 1 & 2 & 3 & $T$ & 1 & 2 & 3 & $T$ \\
\hline \multirow{6}{*}{ 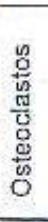 } & \multirow{3}{*}{ Núcleo(s) } & mitótico & & & & & & & & & & & & & & & & \\
\hline & & picnótico & & & & & & & & & & & & & & & & \\
\hline & & cariorrexe & & & & & & & & & & & & & & & & \\
\hline & \multirow{3}{*}{$\begin{array}{c}\text { Quanto } \\
\text { à } \\
\text { superficie }\end{array}$} & a distância & & & $x$ & 1 & & $x$ & $x$ & 2 & & & & & & & & \\
\hline & & justapostos & $x$ & $x$ & & 2 & $\mathrm{x}$ & $x$ & & 2 & & & & & & & & \\
\hline & & em lacunas & & $x$ & & 1 & $x$ & & & 1 & & & & & & & & \\
\hline \multirow{7}{*}{ 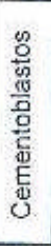 } & \multirow{3}{*}{ Núcleo } & mitótico & & & & & & & & & & & & & & & & \\
\hline & & picnótico & & & & & $x$ & & & 1 & & & & & & & & \\
\hline & & cariorrexe & & & & & & & & & & & & & & & & \\
\hline & \multirow{2}{*}{$\begin{array}{l}\text { Quanto à } \\
\text { disposição }\end{array}$} & em paliçada & $x$ & & & 1 & & & & & $x$ & $x$ & & 2 & & $x$ & $x$ & 2 \\
\hline & & ao acaso & & $x$ & $\mathrm{x}$ & 2 & $x$ & $x$ & $x$ & 3 & & $x$ & $\mathrm{x}$ & 2 & $x$ & $x$ & $x$ & 3 \\
\hline & \multirow{2}{*}{$\begin{array}{l}\text { Quanto à } \\
\text { superficie }\end{array}$} & justapostos & $\mathrm{x}$ & & $x$ & 2 & & $x$ & $x$ & 2 & $x$ & $x$ & $x$ & 3 & $x$ & $x$ & $x$ & 3 \\
\hline & & a distância & & $x$ & & 1 & $x$ & $x$ & $x$ & 3 & & & & & & & & \\
\hline \multirow{6}{*}{ 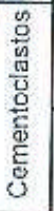 } & \multirow{3}{*}{ Núcleo(s) } & mitótico & & & & & & & & & & & & & & & & \\
\hline & & picnótico & & & & & & & & & & & & & & & & \\
\hline & & cariorrexe & & & & & & & & & & & & & & & & \\
\hline & \multirow{3}{*}{$\begin{array}{c}\text { Quanto } \\
\text { à } \\
\text { superlicie }\end{array}$} & a distāncia & & & & & & & & & & & & & & & & \\
\hline & & justapostos & & & & & & & & & & & & & & & & \\
\hline & & nas lacunas & & & & & & & & & & & & & & & & \\
\hline
\end{tabular}
$T=$ total; $x=$ presença; $c l=c o m ; s i=$ sem; reab. = reabsorçäo; CGMls = células gigantes multinucleadas
inflamatórias

FIGURA 41 - Distribuição dos achados microscópios referentes aos fenômenos morfologicamente detectados nos animais do Grupo OS 5 
6 - DISCUSSÃO 


\section{6 - DISCUSSÃO}

A movimentação dentária induzida é motivo de vários estudos objetivando-se conhecer e compreender as alterações que ocorrem nos tecidos ósseo alveolar, dentário e no ligamento periodontal $\left.\right|^{4,5,10,28,45,49,51,55,61,62}$. Os trabalhos utilizam variada metodologia, diversificando a intensidade e o tipo de força, os modelos experimentais, e as alterações locais e gerais $4,5,10,28,45,49$, $51,55,61,62$. Este trabalho objetivou analisar as alterações teciduais em animais submetidos à ovariectomia.

A padronização de uma força ótima, que produza movimentação dentária em um tempo curto, não acarretando danos aos tecidos e sem causar desconforto ao paciente constitui-se em um dos principais requisitos da ortodontia e padronizar essas forças ótimas com alterações locais e gerais do paciente, obtendo-se uma integração que permita uma movimentação dentária segura tem sido almejada pela ortodontia.

A movimentação dentária induzida envolve tecidos que apresentam graus variados de adaptação ao estresse mecânico, tendo o tecido ósseo uma grande capacidade adaptativa, o cemento uma menor capacidade e o ligamento periodontal contendo células e fibras colágenas com reação diversificada frente ao estresse mecânico. Estes tecidos além de se adaptarem ao estresse mecânico fcam à mercê de fatores gerais e locais que podem interferir na sua adaptação. Conhecer as relações destes tecidos frente a estes fatores permite adaptar as forças mecânicas e proporcionar tratamento ortodôntico a um número maior e variado de pacientes.

Este trabalho escolheu como animais experimentais o rato, bastante comum a numerosos trabalhos e que permite uma extrapolação segura, mas com ressalvas, dos resultados para os humanos; portanto quanto à utilização de animais experimentais, destaca-se a necessidade de critérios, 
cautela, discernimento e conhecimento quando da extrapolação dos resultados para os humanos.

Entre as vantagens de se utilizar o rato como animal experimental têm-se a facilidade de obtenção deste animal; um maior controle genético, pois as ninhadas são grandes, permitindo maior padronização; a manutenção a um custo baixo, requerendo pouco espaço e sem necessidade de cuidados e pessoal especializados; o fácil manuseio devido ao seu pequeno tamanho e à não agressividade ${ }^{5,15,28,62}$.

Os ratos são animais monofiodontes e possuem incisivos com crescimento contínuo, diferindo nestes aspectos da dentição humana, mas os dentes molares, envolvidos neste trabalho, apresentam maior semelhança, respeitando-se o tamanho e alguns detalhes anatômicos.

As restrições à utilização do rato como modelo experimental para a movimentação dentária induzida refere-se a metodologias com comparação de intensidade de forças, pois a boca e os dentes pequenos do rato dificultam a adaptação de aparelhos especiais e reativações controladas de forças, o que não foi objetivo deste trabalho, permitindo, assim, o uso destes animais ${ }^{26}$.

O primeiro molar superior dos ratos apresenta-se pentarradicular, com as raízes mesiovestibular e distovestibular maiores e mais propícias para estudo, inclusive por serem obtidas no mesmo corte microscópico ${ }^{15,26}$. Uma diferença contrastante entre os molares de ratos e de humanos é a deposição de cemento celular no terço apical radicular nos dentes dos ratos, o que não interfere com nosso propósito experimental que analisou o terço cervical, onde ocorre cemento acelular e fino, semelhante ao da dentição humana ${ }^{15,28}$.

Em relação ao tecido ósseo alveolar notam-se, nos ratos, poucos espaços medulares e uma maior densidade, com muitas linhas de reversão, diferindo-se do tecido ósseo encontrado em humanos ${ }^{41}$, mas que pela freqüência de estudos com movimentação dentária induzida em ratos não causam nenhuma limitação deste modelo experimental. 
No ligamento periodontal, as diferenças entre humanos e ratos são poucas e insignificantes, com as fibras colágenas de Sharpey mostrando inclinação na região cervical e supra-alveolar. Quanto à espessura, à celularidade e à vascularização sangüínea não existem diferenças a considerar ${ }^{41}$.

Analisou-se concomitantemente à movimentação dentária induzida a ovariectomia e a maioria dos trabalhos utiliza o rato como modelo experimental ${ }^{1,3,12,24,28,38,65,66,67,68}$, considerando, os vários autores, que há uma grande similaridade entre estes animais e os humanos quanto ao ciclo reprodutivo e aos efeitos do estrogênio, permitindo-se uma extrapolação segura dos resultados ${ }^{1,3,12,24,28,38,65,66,67,68}$.

O hormônio ovariano estrogênio apresenta várias funções no organismo, tais como desenvolvimento sexual, aumento da intensidade de crescimento ósseo, particularmente dos ossos longos e durante a puberdade, por promover principalmente maior atividade osteoblástica ${ }^{31,64,66,67,69}$. Mesmo assim, a ação dos estrogênios no tecido ósseo não está totalmente e satisfatoriamente esclarecida, reconhecendo-se que há receptores osteoblásticos a este hormônio e que o mesmo pode agir indiretamente no metabolismo ósseo pela regulação de outros hormônios e fatores de crescimento.

Quanto à deficiência de estrogênio, comum na menopausa, conhece-se os seus efeitos, principalmente no tecido ósseo, mas desconhecese como se processam tais efeitos. A principal conseqüência desta depleção está representada pela osteoporose, doença óssea metabólica caracterizada por uma diminuição progressiva da densidade óssea, devido a um aumento da taxa de reabsorção óssea em relação à taxa formação, fragilizando os ossos e tornando-os vulneráveis a fraturas. Frente a estas implicações o tecido ósseo e o estrogênio são bastante estudados com modelos experimentais utilizando principalmente ossos longos e ratos ${ }^{1,12,26,35,38,40,50,56,57,65,66,67,68}$. 
A ovariectomia significa a remoção dos ovários e conseqüentemente o fim da produção de estrogênio, antecipando os efeitos da menopausa. As modificações ósseas devido à ovariectomia são estudadas em tanto em ossos longos $3,12,65,66,67,68$, quanto no osso alveolar ${ }^{16,22,24,28,37}$.

As interações da depleção de estrogênio com o cemento e o ligamento periodontal são menos estudadas e compreendidas, sendo um dos propósitos deste trabalho. Alguns estudos correlacionaram o estrogênio e a movimentação dentária induzida, como os de STOREY ${ }^{54}$, HIRAIDE ${ }^{21}$, HELSSING; HAMMARSTRÖN ${ }^{20}$, PEREIRA ${ }^{39}$, VASCONCELOS ${ }^{61}$, não encontrando na literatura consultada trabalhos envolvendo a ovariectomia e a movimentação dentária induzida, tornando a discussão deste trabalho restrita a uma comparação intergrupos experimentais.

A maior parte dos trabalhos anteriores à década de 80 utilizou as faces externas das raízes mesial e distal dos primeiros molares superiores de ratos para avaliação das alterações teciduais conseqüentes à movimentação dentária induzida. A partir dos anos 80 iniciaram-se estudos destas alterações na área inter-radicular considerada mais sensível aos efeitos do movimento dentário induzido ${ }^{4,5}$. A área inter-radicular é mais susceptível a reabsorções, que ocorrem precocemente, por possuir maior extensão de cemento acelular e por sofrer maior intensidade das forças mecânicas. No presente trabalho, notaram-se nos grupos com movimentação dentária induzida alterações e morfologia nas áreas inter-radiculares compatíveis com as descritas pelos autores citados. Outras alterações comuns às áreas inter-radiculares e que as diferem das áreas radiculares externas, citadas por VASCONCELOS ${ }^{61} \mathrm{e}$ notadas neste trabalho foram áreas hialinas extensas e em maior quantidade, reabsorções ósseas frontal e principalmente a distância, perda da celularidade do ligamento periodontal e desorganização das fibras colágenas, sugerindo que as forças aplicadas atuam com maior intensidade nestas áreas. 
Neste trabalho, optou-se por utilizar ratas com 90 dias de idade por estarem na idade adulta, com formação completa de seus tecidos e órgãos e por terem alcançado a fase reprodutiva e de maturação sexual; assim, os efeitos da ovariectomia podem ser equiparados proporcionalmente aos que ocorrem em mulheres na menopausa ou submetidas à ovariectomia ${ }^{26,28}$. Nessa idade, ainda não são notadas perdas ósseas fisiológicas relativas ao envelhecimento, permitindo uma interpretação quase exclusiva dos efeitos da depleção do estrogênio ${ }^{28}$. Quanto a outros trabalhos envolvendo ovariectomia há grande variação em relação à idade dos animais experimentais, mas mesmo assim nota-se interpretação comparativa entre estes trabalhos ${ }^{1,12,28,58,66,67,68}$.

O período de 50 dias de ovariectomia foi suficiente para promover as alterações conhecidas, principalmente ósseas, decorrentes deste estado geral. O sucesso da indução da depleção do estrogênio foi confirmado pela atrofia das trompas uterinas e pelo aumento de peso dos animais, como relatou WRONSKI et al. ${ }^{66}$.

Em relação às alterações ósseas alveolares em ratas ovariectomizadas, MARQUES ${ }^{28}$ realizou um trabalho experimental analisando os efeitos da ovariectomia em diferentes idades e em diferentes tempos, notando se alterações morfológicas compatíveis com a osteoporose, com o osso alveolar mostrando linhas de reversão, clastos a distância e em lacunas de reabsorção, osteóide e espaços medulares aumentados e numerosos. A autora considerou a idade de 90 dias e o tempo de ovariectomia de 40 dias como ideais para interpretação de alterações ósseas.

MARQUES ${ }^{28}$ utilizou um grupo de ratas com idade de 90 dias e com 40 dias de ovariectomia, similar a um dos grupos experimentais deste trabalho. A autora destacou a presença de numerosos osteócitos, vários com picnose, muitas linhas de reversão e espaços medulares aumentados, principalmente na área inter-radicular. $\mathrm{Na}$ área externa, o ápice da crista óssea 
alveolar variou de redondo a triangular, e a superfície óssea periodontal mostrou osteoblastos com morfologia normal, justapostos e distribuídos ao acaso. No ligamento periodontal, as fibras colágenas estavam individualizadas, e os fibroblastos fusiformes, ovalados e ao acaso. Os vasos sangüíneos eram dilatados e hiperêmicos. Não foram notadas áreas de reabsorção cementária e a taxa de reabsorção óssea pareceu ser maior que a de formação, levando a alterações características da osteoporose.

Apesar de não ter sido objeto de análise e de descrição nos resultados deste trabalho, os aspectos morfológicos encontrados no trabalho de MARQUES ${ }^{28}$ são similares aos encontrados nos grupos experimentais com ovariectomia, do presente estudo, confirmando os efeitos do estrogênio e a metodologia aplicada.

Considerando-se que a ovariectomia foi bem sucedida, cabe a discussão comparativa entre os grupos experimentais deste trabalho.

O grupo C, com animais com 90 dias de idade e sem ovariectomia foi utilizado para comparações com os demais grupos, em que os animais receberam movimentação dentária induzida, com ovariectomia ou não. A análise microscópica dos animais do grupo $\mathrm{C}$ mostrou concordância com alguns relatos da literatura, principalmente com PEREIRA ${ }^{39}$, VASCONCELOS $^{61}$ e MAZZIEIRO ${ }^{29}$, citados por terem metodologia semelhante a deste trabalho, principalmente quanto à idade dos animais e tipo e intensidade de força para obtenção da movimentação dentária induzida.

No grupo $\mathrm{C}$, notou-se superfície óssea periodontal regular e uniforme, com discretas linhas de reversão em todas as áreas sob análise, com crista óssea alveolar arredondada. Os osteoblastos mostraram-se justapostos e em paliçada revestindo a superfície óssea. Não havia lacunas de reabsorção. No osso inter-radicular observaram espaços medulares maiores e linhas de reversão mais acentuadas. O cemento mostrou superf ície uniforme, espessura fina constante e acelular no terço cervical, a partir do qual iniciava-se 
deposição de cemento celular. Os cementoblastos dispunham-se justapostos à superfície e em paliçada, e não ocorreram reabsorções cementárias. No ligamento periodontal, notaram-se rica celularidade e vascularização. Os fibroblastos eram predominantemente fusiformes e fasciculados, poucos com núcleos picnóticos, enquanto os vasos sangüíneos eram pequenos, ora colabados, ora dilatados e hiperêmicos. As fibras colágenas apresentaram-se perpendiculares às superfícies óssea e cementária e individualizadas. Não são observadas alterações significantes das alterações relatadas considerando-se separadamente as áreas externas da raiz e inter-radiculares.

Nos grupos experimentais com movimentação dentária induzida por 1, 3 e 5 dias e sem ovariectomia, respectivamente grupos MD1, MD3 e MD5, os resultados obtidos demonstraram no tecido ósseo poucas lacunas de reabsorção com clastos a distância e justapostos, originando-se uma superfície óssea periodontal recortada, quase sempre acompanhada por linha de reversão e revestida por osteoblastos justapostos, em paliçada e ao acaso. Não houve diferenças entre os tempos experimentais considerando que houve pouco tempo para efeitos reparativos devido ao tempo máximo experimental de cinco dias. Quanto às áreas de pressão e tensão houve maior perda óssea na área de pressão, como está bem estabelecido também em outros trabalhos ${ }^{10,39,51,55,61,62}$. Dentre as áreas de pressão, a maior alteração ocorreu na inter-radicular, em relação à externa, inclusive com reabsorções a distância, o que não ocorreu nas de pressão externa. Nas áreas inter-radiculares, houve linhas de reversão mais proeminentes e espaços medulares maiores.

$\mathrm{Na}$ análise das alterações do cemento nos grupos MD1, MD3 e MD5 ocorreram as mesmas características entre os tempos experimentais, com preservação deste tecido, sem apresentar áreas de reabsorção e com cementoblastos revestindo-no, predominantemente justapostos e em paliçada. Também não houve diferenças entre o cemento das áreas externas e inter- 
radiculares, como não houve entre o cemento submetido a forças de pressão e de tensão.

Nestes mesmos grupos experimentais, o ligamento periodontal mostrou-se diferente em relação ao grupo $\mathrm{C}$, notando-se fibras colágenas distribuídas aleatoriamente, fibroblastos fusiformes e ovalados, fasciculados e desorganizados. Não ocorreram alterações vasculares sangüíneas relevantes, nem processo inflamatório. Entre as áreas de pressão externa e inter-radicular, as mudanças foram mais significativas nesta última, com formação de áreas hialinas principalmente nos tempos experimentais de três e cinco dias, justificando uma maior reabsorção óssea a distância e infiltrado inflamatório mononuclear. Entre os grupos com movimentação dentária e o sem movimentação dentária, as mais significantes alterações diferenciais ocorreram nos espaços inter-radiculares.

As alterações notadas nos grupos MD1. MD3 e MD5, com movimentação dentária induzida e sem ovariectomia, são compatíveis com as relatas por PEREIRA ${ }^{39}$, VASCONCELOS ${ }^{61}$ e MAZZIEIRO ${ }^{29}$, que desenvolveram trabalhos semelhantes. As alterações teciduais ocorridas nestes grupos serviram de parâmetro para interpretação comparativa dos grupos em que a movimentação dentária ocorreu em animais ovariectomizados.

Os grupos experimentais com movimentação dentária e com ovariectomia, representados pelo grupos OV1, OV3 e OV5, apresentaram entre si as mesmas alterações discutidas anteriormente. Portanto, entre os tempos experimentais destes grupos não ocorreram alterações teciduais significativas.

Nas ratas ovariectomizadas e com movimentação dentária induzida (Grupos OV1, OV3 e OV5) notaram-se alterações mais significativas em relação aos animais não ovariectomizados (Grupos MD1, MD3 e MD5), 
particularmente na região inter-radicular e na área correspondente a forças de pressão.

Nos grupos OV1, OV3 e OV5, em relação aos grupos MD1, MD3 e MD5, o tecido ósseo nas áreas de pressão externa apresentou-se mais recortado e irregular e com lacunas de reabsorção mais proeminentes, bem como linhas de reversão. Na crista óssea alveolar, o afilamento do ápice foi mais intenso. Quanto aos osteoblastos, estavam mais desorganizados, justapostos e ao acaso e às vezes ausentes. $\mathrm{Na}$ área inter-radicular de pressão ocorreram reabsorções ósseas mais acentuadas, inclusive com reabsorção a distância, notando-se clastos em lacunas e justapostos. Os espaços medulares nesta região eram mais numerosos e maiores, e ocorreram linhas de reversão mais intensas.

Quanto ao cemento e comparando-se os grupos com e sem ovariectomia não ocorreram alterações significativas, principalmente em relação à reabsorção deste tecido, deduzindo-se pela não influência da deficiência de estrogênio neste tecido.

No ligamento periodontal do animais ovariectomizados notou-se maior desorganização das fibras colágenas, com numerosos fibroblastos ora fusiformes, ora ovalados e muitos com núcleos picnóticos. A espessura mostrou-se normal e compatível com as forças de pressão e tensão, estando mais comprimida na área inter-radicular. Ocorreram formação de áreas hialinas, principalmente na área de pressão inter-radicular e mais acentuada nos grupos com três e cinco dias de movimentação dentária induzida. $O$ infiltrado inflamatório mononuclear mostrou-se mais intenso junto às áreas hialinas, não sendo significante quando da ausência destas. Quanto à vascularização, não ocorreram diferenças acentuadas entre os animais ovariectomizados e não ovariectomizados.

Em relação aos animais não ovariectomizados e com movimentação dentária induzida (Grupos OV1, OV3 e OV5) as diferenças 
foram mais significativas apenas nas áreas de pressão, particularmente na área inter-radicular, e mais acentuadamente nos grupos OV3 e OV5.

$\mathrm{Na}$ interpretação das alterações teciduais propostas para estudo neste trabalho e comparando-as entre os grupos experimentais, notaram-se, nos grupos ovariectomizados e nas suas áreas de pressão, discrepâncias maiores e significativas em relação aos animais não ovariectomizados; não ocorrendo a mesma interpretação em relação às áreas sob forças de tensão, deduzindo-se que a influência do estrogênio sobre o tecido ósseo fica mais acentuada quando este é submetido a cargas mecânicas.

Não foram relacionados outros trabalhos na discussão das alterações ocorridas nos animais dos grupos OV1, OV3 e OV5 devido à inexistência de metodologia similar que permitisse análise comparativa.

Os resultados deste trabalho foram obtidos por análise subjetiva e global envolvendo vários parâmetros descritos a partir da microscopia óptica por um examinador experiente e treinado. A utilização de microscopia óptica e coloração com hematoxilina-eosina mostra-se prática, de baixo custo e permite uma análise global de todos os tecidos envolvidos com alto grau de fidelidade, dispensando técnicas de análise e colorações especiais e específicas.

O interesse por este modelo experimental deverá proporcionar novas formas de análise, com a utilização de outras técnicas, tais como morfometria, análise estatística, imuno-histoquímica, aferição do tamanho do espaço periodontal, do osso, do cemento e mesmo de tipos celulares, que deverão ser adotados em função de interesses e objetivos específicos. 
7 - CONCLUSÕES 


\section{7 - CONCLUSÕES}

De acordo com a metodologia empregada na execução deste trabalho e atento às suas limitações, verificamos:

1 - que as alterações celulares e teciduais no ligamento periodontal de dentes submetidos a estresse mecânico não sofreram variações significantes entre os modelos experimentais, com e sem ovariectomia; notando-se apenas alterações mais proeminentes nas áreas de pressão inter-radiculares em relação às áreas de pressão externas;

2 - que as taxas de reabsorção óssea foram significantes ros animais ovariectomizados, principalmente na região de pressão inter-radicular, em relação aos animais não ovariectomizados; não sendo significantes nas áreas de pressão externa e de tensão inter-radicular e externa. Tanto nos Grupos MD1, MD3 e MD5, quanto nos Grupos OV1, OV3 e OV5 verificaram-se taxas de reabsorção óssea mais significativas na região inter-radicular em relação à região externa. Não foram notadas alterações referentes à formação óssea;

3 - que não ocorreram reabsorções dentárias em nenhum dos modelos experimentais com movimentação dentária induzida;

Diante destas constatações, concluímos que a ovariectomia não interfere com o tecido dentário duro durante a movimentação dentária induzida e a interferência com o tecido ósseo, apesar de moderada, pode comprometer a movimentação, merecendo outros estudos com variação metodológica e requerendo mais atenção, quando desta situação na prática ortodôntica. 
REFERÊNCIAS BIBLIOGRÁFICAS 


\section{REFERÊNCIAS BIBLIOGRÁFICAS*}

1 - BAGH, C.M.; MILLER, S.C. Comparison of osteopenic changes in cancellous bone induced by ovariectomy and/or immobilization in adult rats. Anat. Rec., v.239, n.3, p.243-54, Jul. 1994.

2 - BARON, R. Molecular mechanisms of bone resorption by osteoclast. Anat. Rec., v.224, n.2, p.317-24, Jun. 1989.

3 - BERNICK, S.; ERSHOFF, B.H. Histochemical study of bone in estrogentreated rats. J. dent. Res, v.42, n.2, p.981-9, 1963.

4 - BRUDVIK, P.; RYGH, P. Multinucleated cells remove the main hyalinized tissue and start resorption of adjacent root surfaces. Europ. J. Orthodont., v.16, n.4, p.265-73, Aug. 1994.

5 - BRUDVIK, P.; RYGH, P. The initial phase of orthodontic root resorption incident to local compression of the periodontal ligament. Europ. J. Orthodont. , v.15, n.4, p.249-63, Aug. 1993.

6 - CADELL, W. B. Steroids and orthodontic treatment. Aust. Orthodont. J., v.11, n.2, p.130, Oct. 1989.

7 - CANALIS, E.; MCCARTHY, T.; CENTRELLA, M. Growth factors and the regulation of bone remodeling. J. clin. Invest., v.81, n.2, p.277-81, Feb. 1988.

8 - CHAMBERS, T.J.; HALL, T.J. Cellular and molecular mechanisms in the regulation and function of osteoclasts. Vitamins Horm., v.46, p.41-86, 1991.

9 - CLARK, J.H.; SCHRADER, W.T.; O'MALLEY, B.W. Mechanisms of action of steroid hormones. In: WILSON, J.D.; FOSTER, W.D., ed. William textbook of endocrinology. 8.ed. Philadelphia, W. B. Saunders, 1992. Cap. 3, p.35-90.

10 - DAVIDOVITCH, Z. Tooth movement. Critic. Rev. oral Biol. Med., v.2, n.4, p.411-50, 1991.

11 - DEMPSTER, D.W.; LINDSAY, R. Pathogenesis of osteoporosis. Lancet, v.341, n.8848, p.797-801, Mar. 1993.

12 - DEVLIN, H.; FERGUSON, N.W.J.; CARTER, D.H. Cancellous bone resorption in the proximal ilium of the ovariectomized rat. Calcif. Tissue Int., v.46, n.6, p.395-400, Jun. 1990. 
13 - DUURSMA, S.A. et al. Estrogen and bone metabolism. Obstet. gynec. Surv., v.47, n.1, p.38-44, Jan. 1992.

14 - ERIKSEN, E.F. et al. Evidence of estrogen receptors in normal human osteoblast-like cell. Science, v.24, n.4861, p.84-6, Jul. 1988.

15 - FARRIS, E.J. Breeding of the rat. In:

The rat in laboratory investigation. 2.ed. New York, Hafner Publishing, 1963. Cap. 1, p.118.

16 - GILLES, J.A. et al. Oral bone loss in increased in ovariectomized rats. J. Endod., v.23, n.7, p.419-22, Jul. 1997.

17 - GRADY, D. et al. Hormone therapy to prevent disease and prolong life in postmenopausal women. Ann. intern. Med., v.117, n.12, p.1016-37, Dec. 1992.

18 - HAGEL-BRADWAY, S.; DZIAK, R. Regulation of bone cell metabolism. J. oral Path., v.18, n.6, p.344-51, Jul. 1989.

19 - HELLER, I.J.; NANDA, R. Effect of metabolic alteration of periodontal fibers on orthodontic tooth movement, an experimental study. Amer. J. Orthodont. , v.75, n.3, p.239-58, Mar. 1979.

20 - HELLSING, E.; HAMMARSTRÖM, L. The effects of pregnancy and fluoride on orthodontic tooth movements in rats. Europ. J. Orthodont., v.13, n.3, p.223-30, Jun. 1991.

21 - HIRAIDE, T. The effect of estrogen on experimental tooth movement in rats. Nippon Kyosei Shika Gakkai Zasshi, v.45, n.1, p.93-108, Mar. 1986.

22 - HSIEH, Y.D.; DEVLIN, H.; McCORD, F. The effect of ovariectomy on the healing tooth socket of the rat. Archs oral Biol., v.40, n.6, p.529-31, Jun. 1995.

23 - KVAM, E. A study of the cell-free zone following experimental tooth movement in the rat. Transact Europ. Orthodont. Soc., p.419-434, 1970.

24 - LI, X.; NISHIMURA, I. Altered bone remodeling patter of the residual ridge in ovariectomized rats. J. Prosth. dent., v.72, n.3, p.324-30, 1994.

25 - LICHTMAN, R. Perimenopausal hormone replacement therapy. Review of the literature. J. Nurse-Midwifery, v.36, n.1, p.30-48, 1991.

26 - MACAPANPAN, L.C.; WEINMANN, J.P.; BRODIE, A.G. Early tissue changes following tooth movement in rats. Angle Orthodont., v.24. n.2, p.79-95, Apr. 1954. 
27 - MACDONALD, B.R.; GOWEN, M. Cytokines and bone. Brit. J. Rheum., v.31, n.3, p.149-55, Mar. 1992.

28 - MARQUES, K.P. Avaliação microscópica das estruturas periodontais e morfologia óssea alveolar em ratas ovariectomizadas. Dissertação (Mestrado) - Faculdade de Odontologia de Bauru, Universidade de São Paulo, 1998.

29 - MAZZIEIRO, E.T. Biofosfanatos e movimentação dentária induzida: avaliação microscópica de seus efeitos. Tese (Doutorado) Faculdade de Odontologia de Bauru, Universidade de São Paulo, 1998.

30 - MEGHJI, S. Bone remodelling. Brit. dent. J., v.172, n.6, p.235-42, Mar. 1992.

31 - MILLER, S.C. Hormonal regulation of osteogenesis. In: Davidovitch, Z. ed. Biol mechan. tooth erupt. Root Resorp. Ohio, The Ohio State University, 1988, p.71-9.

32 - MOHAN, S.; BAYLINK, D.J. Bone growth factors. Clin. Orthop., n.263, p.30-48, Feb. 1991.

33 - MUNDY, G.R. Local factors in bone remodeling. Rec. Prog. Horm. Res, v.45, p.507-31, 1989.

34 - MUNDY, G.R. Inflammatory mediators and the destruction of bone. J. Periodont. Res., v.26, n.3, p.213-7, May 1991.

35 - NAVEH-MANY, T. et al. Estrogen receptors and biologic response in rat parathyroid tissue and C cell. J. clin. Invest., v.90, n.6, p.2434-8, Dec. 1992.

36 - NUTIK, G.; CRUESS, RL. Estrogen receptors in bone. An evaluation of the uptake of estrogen into bone cells. Proc. Soc. exp. Biol. (N.Y.), v.146, p.265-8, May 1974.

37-PAYNE, J.B. et al. The association between estrogen status and alveolar bone density changes in postmenopausal women with a history of periodontitis. J. Periodontol., v.68, p.24-31, 1997.

38 - PENG, Z.Q.; VÄÄNÄNEN, H.K.; ZHANG, H.X.; TUUKKANEN, J. Longterm effects of ovariectomy on the mechanical properties and chemical composition of rat bone. Bone, v.20, n.3, p.207-12, Mar. 1997. 
39 - PEREIRA. A.A.C. Avaliação microscópica da influência de anticoncepcional e gravidez na movimentação dentária induzida, em especial nos fenômenos da reabsorção dentária. Dissertação (Mestrado) - Faculdade de Odontologia de Bauru, Universidade de São Paulo, 1995.

40 - PIROSHAW, N.A.; GLICKMAN, I. The effect of ovariectomy upon the tissues of the periodontium and skeletal bones. I. The effect of ovariectomy upon the alveolar bone, periodontal membrane, and tibia. Oral Surg., v.10, n.2, p.133-47, 1957.

41 - REITAN, K.; KVAM, E. Comparative behaviour of human and animal tissue during experimental tooth movement. Angle Orthodont., v.41, n.1, p.1-14, Jan. 1971.

42 - REITAN, K.; RYGH, P. Biomechanical principles and reactions. In: GRABER, T. M.; VANARSDALL JR, R. L. Orthodontics current principles and techniques, 2. ed. St. Louis, Mosby, 1994. Cap. 2, p.96-192.

43 - RIGGS, B.L.; MELTON, L.J. The prevention and treatment of osteoporosis. New Engl. J. Med., v.327, n.9, p.620-7, Aug. 1992.

44 - RODAN, G.A.; MARTIN, T.J. Role of osteoblasts in hormonal control of bone resorption $\mathrm{p}$ a hypothesis. [Editorial] Calcif. Tiss. Int., v.33, n.4, p.349-51, 1981.

45 - RYGH, P. Ultrastructural changes of the periodontal fibers and their attachment in rat molar. J. dent. Res., v.81, p.467-80, 1973.

46 - RYGH, P. Elimination of hialinized periodontal tissues associated with orthodontic tooth movement. Scand. J. dent Res., v.82, p.57-73, 1974.

$47-\mathrm{RYGH}$, P. et al. Activation of the vascular system: a main mediator of periodontal fiber remodeling in orthodontic tooth movement. Amer. J. Orthodont. , v.89, n.6, p.453-68, Jun. 1986.

48 - SALOMÃO, J.I.S.; GRANDINI, S.A.; OKAMOTO, T. Processo de reparo em feridas de extração dental em ratas ooforectomizadas. Rev. Fac. Odont. Araçatuba, v.3, n.2, p.183-95, 1974.

49 - SANDY, J.R.; FARNDALE, R.W.; MEIKLE, M.C. Recent advances in understading mechanically induced bone remodeling and their revelance to orthodontic theory and practice. Amer. J. Orthodont. Dentofac. Orthop., v.103, n.3, p.212-22, Mar. 1993.

50 - SCHOT, L.P.C.; SCHUURS, A.H.W.M. Pathophysiology of bone loss in castrated animals. J. Steroid Biochem. Molec. Biol., v.73, n.3, p.461$5,1990$.

51 - SCHWARZ, A. M. Tissue changes incidental to orthodontic tooth movement. Orthodontia Oral Surg. \& Rad. Int. J., v.18, p.331-52, 1932.

52 - SPEROFF, L.; GLASS, R.H.; KASE, N.G. Biossíntese, metabolismo e mecanismo de ação dos hormônios. In: 
Endocrinologia ginecológica clínica e infertilidade. 4.ed. São Paulo, Manole, 1991. Cap. 1, p.1-58.

53 - STEVENSON, J.C et al. Calcitonin and the calcium-regulating hormones in postmenopausal women: effect of oestrogens. Lancet, n.8222, p.693-5, Mar. 1981.

54 - STOREY, E. Bone changes associated with tooth movement, the influence of the menstrual cycle on the rate of tooth movement. Aust. J. Dent., v.58. p.80-8. Apr. 1954.

55 - STOREY, E. Tissue response to the movement of bones. Amer. J. Orthodont., v.64, n.3, p.229-47, Sept. 1973.

56 - TAKANO-YAMAMOTO, T.; RODAN, G.A. Direct effects of $17 \beta$-estradiol on trabecular bone in ovariectomized rats. Proc. nat. Acad. Sci. (Wash.), v.87, p.2172-6, Mar. 1990.

57 - TOBIAS, J.H. et al. High concentrations of $17 \beta$-estradiol stimulate trabecular bone formation in adult female rats. Endocrinology, v.128, n.1, p.408-12, Jan. 1991.

58 - TURNER, R.T. et al. Dehydroepiandrosterone reduces cancellous bone osteopenia in ovariectomized rats. Am. J. Physiol., v.258 (4pt 1), p.E673-7, Apr. 1990.

59 - VÄÄNÄNEN, H.K. Pathogenesis of osteoporosis. Calc. Tiss. Int., v.49, p.s11-4, Jul. 1991. Supplement 1.

60 - VAN PAASSEN, H.C. et al. Oestrogen binding proteins in bone cell cytosol. Calcif. Tiss. Res, v.25, p.249-54, Jun. 1978.

61 - VASCONCELOS, M.H.F. Análise morfológica comparativa do periodonto de sustentação submetido a forças biologicamente excessivas, em ratas adultas sem e sob 0 uso de anticoncepcionais e ratas prenhes. Dissertação (Mestrado) Faculdade de Odontologia de Bauru, Universidade de São Paulo, 1996.

62 - WALDO, C. M.; ROTHBLATT, J. M. Histologic response to tooth moverment in the laboratory rat. J. dent. Res., v.33, n.4, p.481-6, Aug. 1954.

63 - WALLIS, C. The estrogen dillema. Time, v.26, p.36-43, Jun. 1995.

64 - WEST, J.B., ed. Principles of hormones action and endocrine control. In Best and Taylor's physiological basis of medical practice. 12.ed. Baltimore, Willians \& Wilkins, 1990. Cap. 52, p.78294.

65 - WRONSKI, T.J. Estrogen treatment prevents osteopenia and depresses bone turnover in ovariectomized rats. Endocrinology, v.123, n.2, p.681-6, 1988.

66 - WRONSKI, T.J.; LOWRY, P.L.; WALSH, C.C.; IGNASZEWSKI, L.A. Skeletal alterations in ovariectomized rats. Calcif. Tissue Int. v.37, p.324-8, 1985. 
67 - WRONSKI, T.J.; CINTRÓN, M.; DANN, L.M. Temporal relationship between bone loss and incresead bone turnover in ovariectomized rats. Calcif. Tissue Int., v.43, n.3, p.179-83, 1988.

68 - WRONSKI, T.J; DANN, L.M.; SCOTT, K.S.; CINTRÓN, M. Long-term effects of ovariectomy and aging on the rat skeleton. Calcif. Tissue Int. v.45, n.6, p.360-6, Dec. 1989.

69 - ZOFKOVA, I.; KANCHEVA, R.L. Effect of estrogen status on bone regulating hormones. Bone, v.19, n.3, p.227-32, 1996. 
ABSTRACT 


\section{ABSTRACT}

Ovariectomy promotes a depletion in estrogen synthesis, a hormone thats acts over bone metabolism. The aim of this work was to analyse the effects of this condition on dental and bone tissues involved in induced tooth movement. Ovariectomized and not ovariectomized female rats were used and had their first upper molars moved during 24 hours, three and five days. The analysis under light microscopy did not reveal interference on hard dental tissues due to the estrogen depletion, nor resorptions. A sligth raise of bone resorption was noticed in the ovariectomized animals compared to the control group. This study presented differences between the interradicular and external bone areas related to the resorption susceptibility during the tooth movement and the interradiculars areas showing more prominent bone resorption aspects, despite the condition of the rats. 